
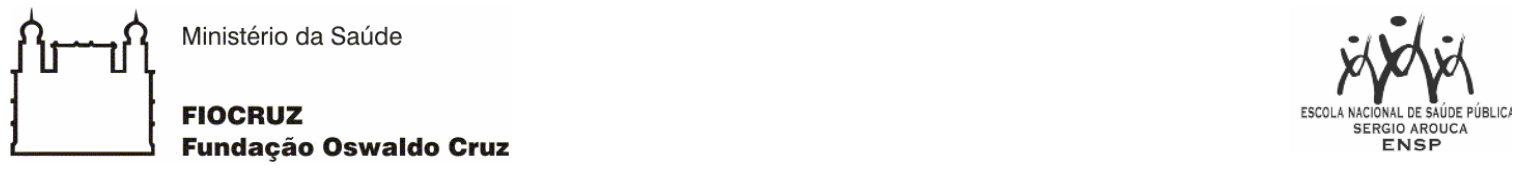

Ricardo Ferreira da Silva

A Análise Multicritério de tecnologias utilizadas na Gestão de Resíduos Sólidos Urbanos

Rio de Janeiro

2017 
Ricardo Ferreira da Silva

A Análise Multicritério de tecnologias utilizadas na Gestão de Resíduos Sólidos Urbanos

Dissertação apresentada ao Programa de Pós Graduação em Saúde Pública, da Escola Nacional de Saúde Pública Sergio Arouca, na Fundação Oswaldo Cruz, como requisito parcial para a obtenção do título de Mestre em Saúde Pública. Área de Concentração: Saneamento Ambiental.

Orientador: Prof. Dr. Marcelo Motta Veiga

Rio de Janeiro 
Catalogação na fonte

Fundação Oswaldo Cruz

Instituto de Comunicação e Informação Científica e Tecnológica em Saúde

Biblioteca de Saúde Pública

S586a Silva, Ricardo Ferreira da.

A análise multicritério de tecnologias utilizadas na gestão de resíduos sólidos urbanos / Ricardo Ferreira da Silva. -- 2017.

143 f. ; il. color. ; graf. ; tab.

Orientador: Marcelo Motta Veiga.

Dissertação (mestrado) - Fundação Oswaldo Cruz, Escola Nacional de Saúde Pública Sergio Arouca, Rio de Janeiro, 2017.

1. Resíduos Sólidos. 2. Processamento de Resíduos Sólidos. 3. Gerenciamento de Resíduos. 4. Tecnologia. 5. Avaliação Multicritério. I. Título.

CDD - 22.ed. - 363.7285 
Ricardo Ferreira da Silva

\section{A Análise Multicritério de tecnologias utilizadas na Gestão de Resíduos Sólidos Urbanos}

Dissertação apresentada ao Programa de Pós Graduação em Saúde Pública, da Escola Nacional de Saúde Pública Sergio Arouca, na Fundação Oswaldo Cruz, como requisito parcial para a obtenção do título de Mestre em Saúde Pública. Área de Concentração: Saneamento Ambiental.

Aprovada em: 31 de maio de 2017.

Banca Examinadora

Prof. Dr. Marcelo Guimarães Araújo

Fundação Oswaldo Cruz - Escola Nacional de Saúde Pública Sergio Arouca

Prof. Dr. Dalton Marcondes Silva

Fundação Oswaldo Cruz - Escola Nacional de Saúde Pública Sergio Arouca

Prof. Dr. Marcelo Bessa de Freitas

Fundação Oswaldo Cruz - Escola Nacional de Saúde Pública Sergio Arouca

Prof. Dr. Marcelo Motta Veiga (Orientador)

Fundação Oswaldo Cruz - Escola Nacional de Saúde Pública Sergio Arouca

Rio de Janeiro 


\begin{abstract}
À Ana Lucia, Minha progenitora.

A qual com muito afinco e perseverança, Sempre com mensagens de carinho e esperança Nunca abdicou de ser minha orientadora.
\end{abstract}

Á Luciana e Tatiana, sempre tão ternas, De minha família, são companheiras as fraternas.

À Valeria Lima, que há tempos segue como brava companheira, Lutando lado a lado, me complementando cada conquista. Pois dividimos os sonhos que mesmo a perder de vista, Construímos degrau a degrau, fileira a fileira.

\author{
A todas, \\ meu coração \\ minha gratidão \\ Por tudo já escrito \\ e pelo ainda não dito, \\ Eis a dedicação.
}




\section{AGRADECIMENTOS}

Agradeço a ENSP/Fiocruz pela oportunidade de formação e pelos conhecimentos adquiridos.

Ao meu sempre presente orientador, Marcelo Motta Veiga, que invariavelmente trazia palavras de incentivo, tranquilidade e equilíbrio colaborou de modo impar para minha formação e crescimento tanto acadêmico quanto profissional.

A minha família, em especial minha mãe, Ana Lúcia Ferreira da Silva que tanto contribui para minha tranquilidade com seu sempre presente amor e compreensão. Minhas irmãs, Luciana Ferreira e Tatiana Ferreira, que me proporcionam um ambiente tranquilo e agradável.

A minha noiva, Valeria Lima, que por sacrifícios hercúleos e compreensão infinita, me acompanhou e apoiou com tamanha dedicação.

Ás minhas companheiras de jornada e amigas para a vida, Lícia e Anna.

À pequena notável, Mila, que sempre gentil e teimosamente insistiu em me ajudar.

Por fim, aos meus ancestrais e orientadores que, presentes ou não, tanto influenciam para meu crescimento. 
Ou encontramos um caminho, ou criamos um.

Aníbal Barca, de Cartago.- séc. III, a.c. 


\section{RESUMO}

O presente trabalho analisou a aplicação do método de avaliação multicritério como ferramenta de auxilio a escolha de tecnologias de tratamento de RSU, considerando as características, vantagens e desvantagens das tecnologias disponíveis para tratamento dos RSU; assim como critérios para escolha das tecnologias mais adequadas para tratamento de resíduos segundo a Análise Multicritérios (AHP); além disso, analisou as possíveis combinações de tecnologias para tratamento. Como metodologia de pesquisa, aplicou-se a revisão bibliográfica, e para a aplicação do método de analise multicritério, consultaram-se especialistas na área de gestão de resíduos sólidos urbanos. Esta consulta se realizou através do preenchimento de formulários (apêndice II) por especialistas da área, sem que suas identidades e formações fossem de conhecimento do pesquisador, de modo a evitar que suas respectivas formações pudessem influenciar a interpretação dos dados. Todavia, como forma de considerar a experiência de cada especialista, houve outra forma de consultá-los, de modo paralelo a análise AHP. Desta forma, tornou-se comparar a aplicação do método AHP com uma consulta direta. As possibilidades de tratamento de resíduos sólidos urbanos foram organizadas segundo os custos principais envolvidos, que são os custos de coleta (com ou sem segregação de resíduos na fonte geradora), custos internos do empreendimento e custos externos. As tecnologias consideradas foram o uso de aterros sanitários, a incineração combinada com o tratamento biológico dos resíduos e a incineração indissociada destes mesmos resíduos. Como resultados, evidenciou-se que não há um consenso entre os especialistas quanto ao uso de tecnologias de tratamento de resíduos sólidos urbanos.

Palavras-chave: Resíduos Sólidos. Processamento de Resíduos Sólidos. AHP. Análise Multicritério. 


\section{ABSTRACT}

The present work analyzed the application of the multicriteria evaluation method as a tool to assist in the selection of MSW treatment technologies, considering the characteristics, advantages and disadvantages of the available technologies for MSW treatment; as well as criteria for choosing the most appropriate technologies for waste treatment according to Multicriteria Analysis (AHP); in addition, analyzed the possible combinations of technologies for treatment. As a research methodology, the literature review was applied, and for the application of the multicriteria analysis method, specialists were consulted in the area of urban solid waste management. This consultation was carried out by filling in forms (appendix II) by experts in the field, without their identities and formations being known to the researcher, in order to avoid that their respective formations could influence the interpretation of the data. However, as a way of considering the experience of each specialist, there was another way of consulting them, in parallel to the AHP analysis. In this way, it became possible to compare the application of the AHP method with a direct query. The possibilities of urban solid waste treatment were organized according to the main costs involved, which are collection costs (with or without segregation of waste at the generating source), internal costs of the project and external costs. The technologies considered were the use of landfills, incineration combined with the biological treatment of waste and the incineration without the associated waste. As results, it was evidenced that there is no consensus among the experts regarding the use of urban solid waste treatment technologies.

Keywords: Solid Waste. Solid Waste Processing. AHP. Multi-criteria analysis. 


\section{LISTA DE FIGURAS}

Figura 1 - Biodigestor Canadense. Fonte: Torres, 2012. Vista de perfil........... 52

Figura 2 - Exemplo de modelo de Biodigestor. Vista superior......................... 53

Figura 3 - compostador da empresa SoloStocks (http://www.solostocks.com.br)

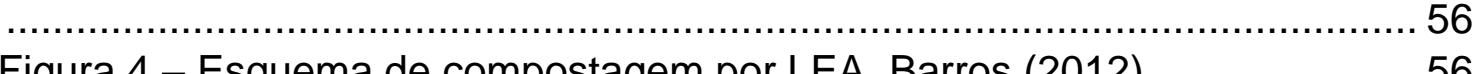

Figura 4 - Esquema de compostagem por LEA. Barros (2012) ..................... 56

Figura 5 - Adaptado de Detroit Stoker Company, 2012 - QUEIMA EM MASSA

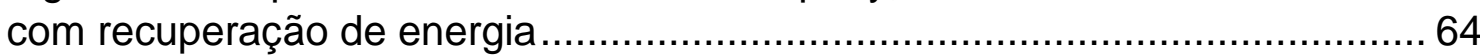

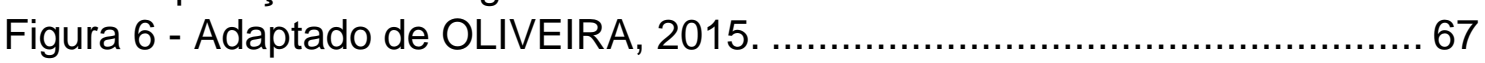

Figura 8 - Desenhos esquemáticos dos gaseificadores contracorrente e de leito fluidizado. Fonte: (Cortez, Lora e Gómez,2009 apud FEAM, 2013)................. 71

Figura 9 - Gaseificador Imbert e veículo acionado por gás de biomassa.

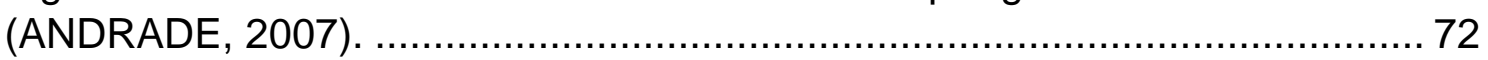

Figura 10- Esquema de um gaseificador contracorrente (ANDRADE, 2007) ... 73

Figura 11 - Esquema de um gaseificador concorrente (ANDRADE, 2007). ..... 74

Figura 12 - Esquema de um gaseificador de fluxo cruzado. (ANDRADE, 2007)

Figura 13 - Esquema de um sistema de gaseificação em leito fluidizado

circulante. (ANDRADE, 2007)............................................................... 76

Figura 14 - Diagrama de fluxo do processo no reator pirolítico. Adaptado de

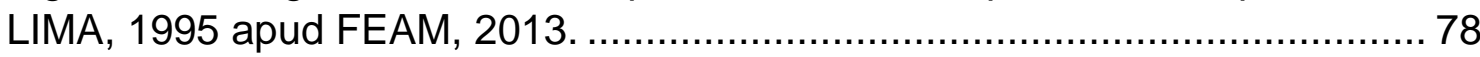

Figura 15 - Fonte:

http://www.plasma.inpe.br/LAP_Portal/LAP_Sitio/Texto/Processos_a_Plasma.ht

$\mathrm{m}$

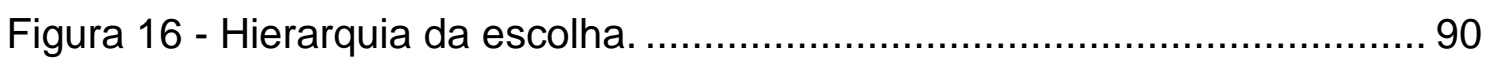




\section{LISTA DE GRÁFICOS}

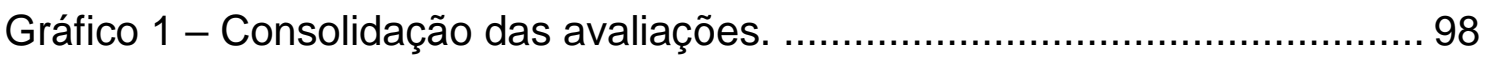

Gráfico 2 - Avaliações validadas pela metodologia. ..................................... 98

Gráfico 3 - Cenário 1 - considerado o custo mais elevado para a implantação

dos empreendimentos para tratamento de RSU.

Gráfico 4 - Validação do cenário 1 pela metodologia AHP........................... 101

Gráfico 5 - Cenário 2 com todas as avaliações......................................... 102

Gráfico 6 - Resultados a partir dos formulários consistentes para o cenário 2.

Gráfico 7 - Custo de Logística a partir das notas dos especialistas. ............. 104 Gráfico 8 - Custo de Implantação de tecnologias de tratamento a partir das avaliações dos especialistas.

Gráfico 9 - Custo dos Impactos socioambientais a partir das notas dos especialistas. 


\section{LISTA DE TABELAS}

Tabela 1 - Quantidade de Municípios brasileiros com iniciativa de coleta seletiva. (ABRELPE,2015).

Tabela 2 - Quantidade de Municípios por Tipo de Disposição Final Adotada2015 (ABRELPE, 2015). 36

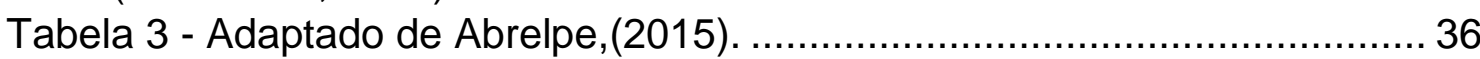

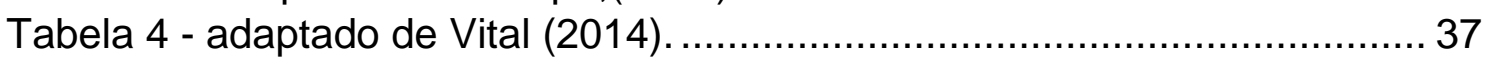

Tabela 5 - Dimensões do biodigestor. Fonte: Oliver (2008).......................... 53

Tabela 6 - Dimensões da manta de PVC. Fonte: Adaptado de Oliver, 2008. .. 53

Tabela 7 - Efeitos da Temperatura na Pirólise. Fonte: Lima, 1995 apud FEAM,

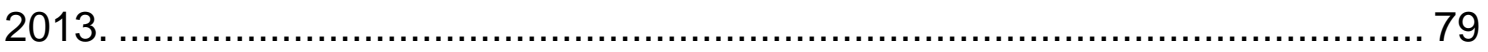

Tabela 8 - Valores dos AHP (SAATY, 2008) ………………………......... 92

Tabela 9 - Importância AHP (SAATY, 2008) ……….................................. 92

Tabela 10 - Resultado da avaliação (Apêndice II) ........................................ 93

Tabela 11 - Matriz formada a partir de formulário preenchido (colaborador

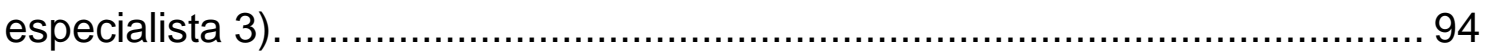

Tabela 12 - Matrizes normalizadas........................................................... 94

Tabela 13 - Prioridade Média Local para cada alternativa ............................. 95

Tabela 14 - Pesos ou nível de importância de cada critério considerado........ 95

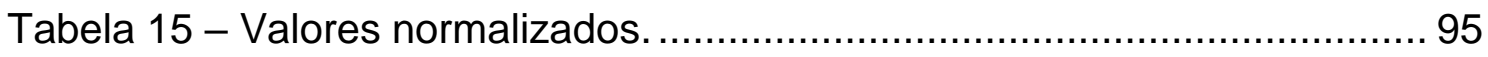

Tabela 16 - Resultados da avaliação de um especialista conforma a metodologia, onde o valor menor indica a alternativa de menor custo............. 96

Tabela 17 - Índice Randômico de Consistência (IR)..................................... 97

Tabela 18 - Comparativo consolidado a partir da avaliação pela metodologia

AHP e avaliação direta, por cada colaborador. .......................................... 107

Tabela 19 - Consolidado do gráfico 7 com testes de Moda e desvio Padrão.124

Tabela 20 - Consolidado do gráfico 8 com testes de Moda e desvio Padrão. 125

Tabela 21 - Consolidado do gráfico 8 com testes de Moda e desvio Padrão. 126 


\section{SUMÁRIO}

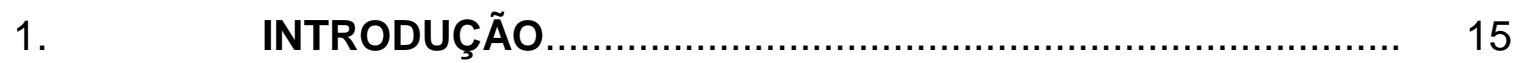

2. OBJETIVO GERAL................................................. 21

2.1. OBJETIVOS SECUNDÁRIOS............................................ 21

3. METODOLOGIA ..................................................... 22

3.1. A FERRAMENTA AHP................................................ 27

4. REFERENCIAL TEÓRICO................................................. 32

4.1. CARACTERIZAÇÃO DE RESÍDUOS SÓLIDOS.................... 32

4.2. DISPOSIÇÃO FINAL DOS RSU........................................ 34

4.2.1. Lixão ou vazadouro ....................................................... 39

4.2.2. Aterro controlado ........................................................ 39

4.2.3. Aterro sanitário............................................................ 40

4.3. TECNOLOGIAS DISPONÍVEIS DE TRATAMENTO DE 42

4.3.1. Tratamento biológico ................................................... 42

4.3.1.1. Biodigestores.............................................................. 43

4.3.1.1.1. Biodigestor Tipo Chinês....................................................... 48

4.3.1.1.2. Biodigestor Tipo Indiano................................................... 48

4.3.1.1.3. Biodigestor Tipo Canadense............................................... 48

4.3.1.2. Co-digestão...................................................................... 54

4.3.1.3. Compostagem........................................................... 54

4.3.1.4. Vermicompostagem..................................................... 58

4.3.2. Tratamento térmico .................................................... 60

4.3.2.1.1. Incineração............................................................. 57

4.3.2.1.1.1. Incineração em grelha.................................................... 59

4.3.2.1.1.2. Incineração em leito fluidizado......................................... 62

4.3.2.1.3. Combustível Derivado de Resíduo..................................... $\quad 67$

4.3.2.1.4. Gaseificação...................................................................... 
4.3.2.1.4.1. Tipos de gaseificadores................................................... 73

4.3.2.1.4.2. Gaseificador contracorrente ("up draft")................................ 73

4.3.2.1.4.3. Gaseificador concorrente ("downdraft").................................. 74

4.3.2.1.4.4. Gaseificador fluxo cruzado ("cross flow")................................. 75

4.3.2.1.4.5. Gaseificador de leito fluidizado ("fluidized bed")...................... 76

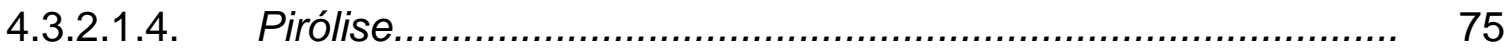

4.3.2.1.5. $\quad$ Arco de Plasma.................................................................... 80

4.4 OS TRATAMENTOS DE RSU E OS RISCOS À SAÚDE COLETIVA.

83

5. RESULTADOS E DISCUSSÃO ……................................... 86

5.1. RESULTADOS.............................................................. 93

5.1.1 Consolidação das avaliações............................................... 107

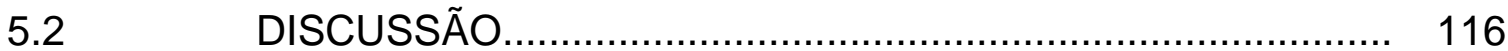

$6 \quad$ CONSIDERAÇÕES FINAIS ............................................ 128

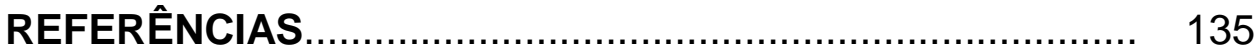

APÊNDICE I........................................................... 163

APENDICE II........................................................... 166 


\section{INTRODUÇÃO}

A geração de resíduos sólidos é um fator que está associado diretamente a atividade humana. Corroborando esta ideia, pode-se atentar aos achados antropológicos, onde se identifica um povoado, uma sociedade ou uma cultura através de seus resíduos deixados. (EIGENHEER, 2009)

Dinastias e períodos históricos da humanidade se identificam através de objetos produzidos conforme seu tempo, ou melhor dizendo, sua cultura. E como qualquer produto, para ser efetivamente concluído teve em seu histórico, recursos empregados desde a extração, manufatura e conclusão. A estes recursos entende-se por matéria prima, logística, energia e habilidades necessárias. (BRASIL, 2010a)

Em todos os aspectos envolvidos nas produções de quaisquer objetos há a geração de resíduos. E após a revolução industrial, a geração destes afeta a capacidade da natureza em degradá-los.

“... a geração per capita e a caracterização dos resíduos sólidos tem a ver com o desenvolvimento econômico de um país, o poder aquisitivo e o correspondente consumo de uma população. Famílias mais abastadas, cidades maiores e países mais ricos apresentam indicadores de geração per capita de resíduos sólidos superiores às famílias mais pobres, cidades menores e países em desenvolvimento." (CAMPOS, 2012)

Conforme descrito na Política Nacional de Meio Ambiente, o conceito de poluição como:

" a degradação da qualidade ambiental resultante de atividades que direta ou indiretamente: a) prejudiquem a saúde, a segurança e o bem-estar da população; b) criem condições adversas às atividades sociais e econômicas; c) afetem desfavoravelmente a biota; d) afetem as condições estéticas ou sanitárias do meio ambiente; e) lancem matérias ou energia em desacordo com os padrões ambientais estabelecidos; (Brasil, 1981)." 
Assim, a capacidade de geração de resíduos na atualidade é maior que a capacidade natural de depurar as substâncias lançadas no meio.

Com o advento de novas tecnologias, novas substâncias são produzidas. Novos materiais permitem novas construções e novos produtos. Estas novas produções e substâncias geram novos resíduos, com tempo e forma de depuração na natureza que, não raro, necessitam da intervenção humana para minimizarem seus impactos no ambiente.

Entende-se como impacto ambiental "qualquer alteração das propriedades físicas, químicas, biológicas do meio ambiente, causada por qualquer forma de matéria ou energia resultante das atividades humanas que afetem diretamente ou indiretamente: -A saúde, a segurança, e o bem estar da população; -As atividades sociais e econômicas; -A biota; -As condições estéticas e sanitárias ambientais; -A qualidade dos recursos ambientais" (CONAMA,1986)

Com o crescimento populacional associado aos modelos de produção capitalista, onde a maximização do lucro gerado pelo aumento do consumo de bens, potencializa a produção destes e consequentemente, a geração de resíduos.

"O consumo torna-se, assim, num complexo processo pelo qual as corporações têm regulado os comportamentos dos indivíduos. Se de um lado o Estado produz regulação pela via do indivíduo-cidadão, que constitui a relação formal de poder soberano, de outro as grandes empresas processam regulação pela via do indivíduo-consumidor. Hoje, essa regulação privada, que é crescentemente corporativa no Brasil e no mundo, tem interferido nas relações sociais de modo a condicioná-las para as estratégias de consumo." (ANTAS, 2007)

A situação se agrava quando a durabilidade destes bens é reduzida propositalmente. $A$ isto se chama obsolescência programada.

"O aumento do consumo constitui um dos traços essenciais do movimento de expansão capitalista, como impulso à acumulação privada. Entretanto, no capi- 
talismo tardio, o desenvolvimento das forças produtivas articula-se, contraditória e dialeticamente, ao "desperdício institucionalizado" como modo privilegiado de acelerar a velocidade de rotação do capital, posto que a ampliação do círculo do consumo no interior da circulação é condição precípua para a realização do valor. Assim, a obsolescência programada das mercadorias expõe uma das faces mais destrutivas do capitalismo contemporâneo." (SILVA, ARAÚJO e SANTOS, 2012)

Ou quando um produto dura, mas o grupo social o identifica como ultrapassado, segregando o indivíduo que o possua a margem deste grupo. Aí temse a obsolescência percebida.

Desta forma, com o aumento da população, crescem as demandas por produtos, os quais alimentam os lucros. E em todos os momentos a geração de resíduos acompanhada de maneira direta este processo, e portanto, esta ideologia.

"As origens da sociedade focada no consumo, em contraposição às tradicionais, voltadas para o trabalho e à produção, remontam movimentos comerciais ocorridos na Europa a partir do século XV que estimularam a revolução industrial, iniciada em meados do século XVIII. A revolução industrial trouxe consigo o fortalecimento da acumulação de riqueza como um valor fundamental, apoiado na ética protestante, que propiciou a aceitação do modelo." (GODECKE, 2012)

Todavia, os meios de produção, o capitalismo e todos os mecanismos envolvidos nesta cadeia cíclica não são tão eficientes em resolver a geração dos resíduos envolvidos em cada um dos processos.

As soluções atuais deste modelo de desenvolvimento econômico não acompanham o volume de bens produzidos. Logo, desenvolver mecanismos que possibilitem a redução, a reutilização ou a reciclagem destes resíduos é fundamental para a manutenção das condições da natureza em degradar tais substancias. 
Um norteador pragmático que pode fomentar mecanismos que corrijam este processo de geração de resíduos é fornecido pela tríade de princípios que compõem o desenvolvimento sustentável, também conhecido como Triple Bottle Line (ou People, Planet and Proift, ou, em português, PPL - Pessoas, Planeta e Lucro ou simplesmente 3P's), a saber: economicamente viável, socialmente justo e ecologicamente correto. Desta forma, nenhum dos princípios deve ser mais importante ou menos importante que o outro para se alcançar o equilíbrio perfeito entre eles. Alvarenga et al (2013) apresentam a expressão Triple Bottom Line (TBL), que segundo os autores foi cunhada por John Elkington, considerado uma referência em responsabilidade corporativa e desenvolvimento sustentável. Voltado para empresas de petróleo e gás a expressão surge como um norteador para se alcançar a prosperidade econômica, justiça social e proteção ao meio ambiente.

Neste contexto, tem-se as relações entre população e consumo, apresentadas por Silva, Barbieri e Monte-Mór (2012), onde defendem que as chamadas transições demográficas afetam a geração de consumo e consequentemente a geração de resíduos. Segundo esta publicação, o crescimento populacional não está diretamente relacionado à geração dos resíduos, mas aos hábitos de consumo, o grau de escolaridade, a expectativa de vida e o nível socioeconômico. De modo geral, quanto maior a expectativa de vida e o nível socioeconômico, opta-se por um maior consumo de produtos de consumo rápido e por bens pouco duráveis.

Conforme apresentam Zambon et al. (2015), existe uma relação entre novos modelos de produtos de consumo o descarte de modelos defasados, trazendo a percepção de redução de utilidade do produto. Tal percepção promove a necessidade de consumo de novos modelos de produtos ou novos produtos. A inovação constante promovida pela indústria acelera a obsolescência total e contribui para o aumento da geração de resíduos sólidos de modo direto.

Berríos (2006) corrobora com Zambon et al. (2015) ao descrever a atual relação de consumo como consumo de resíduos, posto que ou são descartá- 
veis ou são rapidamente superados de novos produtos. Grosso modo, pode-se dizer que a economia atual é pautada na geração de resíduos.

O uso de aterros sanitários é uma solução para a disposição final dos rejeitos gerados, conforme preconiza a lei 12.305/2010, em seu art. $3^{\circ}$, item VIII. Contudo, a mesma lei estipula que somente devem ser lançados nos aterros os chamados rejeitos, que são os resíduos que "resíduos sólidos que, depois de esgotadas todas as possibilidades de tratamento e recuperação por processos tecnológicos disponíveis e economicamente viáveis, não apresentem outra possibilidade que não a disposição final ambientalmente adequada" (BRASIL, 2010a).

Os mesmos aterros têm vida útil determinada em seu projeto original, conforme determina a norma ABNT NBR 8.419 (1996). Ao se considerar que aterros sanitários serão passivos ambientais ao fim deste prazo, que exigirão custos de monitoramento, além dos custos para a sua construção e operação. Somado a isto, há ainda o tempo necessário para este monitoramento, que é de no mínimo 20 anos após o encerramento de suas atividades, conforme a norma ABNT NBR 13.896 (1997).

Como as necessidades elementares da vida humana são inerentes à manutenção da vida, nunca cessarão. A geração de resíduos dessa natureza tende a ser positiva e de modo proporcional. Portanto, a geração de resíduos orgânicos derivados destas necessidades são uma fonte praticamente inesgotável de resíduos.

Somado a isso tem-se o fato das cidades apresentarem um modelo de sociedade, e portanto, de comportamento humano da atualidade mais profícuo na atualidade, aumentando cada vez mais a densidade demográfica (ABIKO et al, 1995).

Concomitante a esta realidade, há ainda a relação entre saúde e saneamento. Isto se salienta a partir do significado e saneamento descrito no dicionário Aurélio como sanear, tornar habitável. Em linhas gerais, pode-se compre- 
ender om um ato de levar saúde a um local e a sua população. A Política Nacional de Promoção da Saúde, mesmo após sua redefinição dada pela Portaria do 2446/2014 (Ministério da Saúde, 2014), tem entre seus objetivos apoiar espaços saudáveis, conforme descrito no art. $7^{\circ}$ favoráveis ao desenvolvimento humano e bem estar. A mesma portaria reconhece que a promoção de ambientes e espaços saudáveis são temas que tangenciam outros aspectos de relevância social, como o urbanismo e o saneamento, evidenciado no art. $8^{\circ}$,item IV. Historicamente, o Brasil teve sua legislação e Saúde associada às condições sanitárias dos municípios, conforme mostra Sousa e Costa (2016).

Tal relação é consolida a partir da Lei Federal 8.080 de setembro de 1990, que trata da criação do Sistema Único de Saúde (SUS). Esta lei afirma em seu art. $2^{\circ}$ que a saúde é um direito fundamental do ser humano e é dever do Estado garantir as condições necessárias para isso. Ainda, tem-se nos próximos parágrafos:

"§ 1ㅇ O dever do Estado de garantir a saúde consiste na formulação e execução de políticas econômicas e sociais que visem à redução de riscos de doenças e de outros agravos e no estabelecimento de condições que assegurem acesso universal e igualitário às ações e aos serviços para a sua promoção, proteção e recuperação."

"\$ 2ํ O dever do Estado não exclui o das pessoas, da família, das empresas e da sociedade."

E em seu art. 6º, a relação entre saúde e saneamento básico, se torna definitiva nos itens;

"Il - a participação na formulação da política e na execução de ações de saneamento básico; $V$ - a colaboração na proteção do meio ambiente, nele compreendido o do trabalho; e IX - a participação no controle e na fiscalização da produção, transporte, guarda e utilização de substâncias e produtos psicoativos, tóxicos e radioativos;" (BRASIL, 1990) 
Dentre as soluções existentes, este trabalho se concentrará em analisar tecnologias de tratamento de resíduos sólidos urbanos que possam ser utilizadas de modo concomitante de acordo com o perfil das cidades, reduzindo o volume destes resíduos e aumentando a vida útil aterros sanitários no Brasil.

\section{OBJETIVO GERAL}

- Analisar a aplicação do método de avaliação multicritério como ferramenta de auxilio a escolha de tecnologias de tratamento de RSU.

\subsection{OBJETIVOS SECUNDÁRIOS}

- Analisar as características, vantagens e desvantagens das tecnologias disponíveis para tratamento dos RSU;

- Analisar critérios para escolha das tecnologias mais adequadas para tratamento de resíduos segundo a Análise Multicritérios (AHP);

- Analisar as possíveis combinações de tecnologias para tratamento. 


\section{METODOLOGIA}

Como metodologia aplicada ao estudo, foi utilizada a revisão bibliográfica nas bases Scopus (via https://www.scopus.com/), SciELO (via http://www.scielo.org/php/index.php), Lilacs (via http://bvsalud.org/) e Pubmed (via www.pubmed.gov), nos idiomas português e inglês pelo fato de serem os idiomas de domínio do pesquisador. Assim, os demais idiomas não foram considerados, nem publicações anteriores ao período de tempo citado.

Desta forma, utilizou-se nesta pesquisa o intervalo de tempo de 2010 até 2017 a fim de coletar publicações atualizadas de modo a ser possível acompanhar a evolução da efetividade da Política Nacional de Resíduos Sólidos.

Como critérios de inclusão comuns para todas as buscas, foram utilizados o período de tempo entre 2010 e 2017, nos idiomas Português e Inglês. Quanto ao tipo de publicação, foram utilizados artigos, artigos de revisão, resumos de conferencias e capítulos de livro.

Quanto às tecnologias de tratamento, foram utilizadas estratégias específicas para cada tipo disponível. Desta forma, tem-se:

- Para BIODIGESTOR ANAERÓBIO a busca foi realizada utilizando-se a seguinte sequência de palavras chave: organic fraction of municipal solid waste AND solid waste processing AND biodigester (Resíduos sólidos municipais + Processamento de Resíduos Sólidos+ biodigestor), chegando a um total de 35 artigos.

- Para CO-DIGESTÃO a busca foi realizada utilizando-se a seguinte sequencia de palavras chave: organic fraction of municipal solid waste AND solid waste processing AND codigestion (Fração orgânica de resíduos sólidos municipais + Processamen- 
to de Resíduos Sólidos + Co-digestão), considerando apenas as publicações do tipo artigos, artigos de revisão, resumos de conferência, que tivessem suas publicações vinculadas às subáreas meio ambiente, energia e engenharia. Ainda que incluíssem palavras chave digestor anaeróbio, metano, biogás, anaerobiose, biorreator, co-digestão anaeróbia. Como critérios de exclusão, condições anóxicas, Demanda Química de Oxigênio, tratamento de aguas servidas, esgoto, lodo, digestão de lodo e publicações da área de agricultura. Assim, chegou-se a um total de 52 artigos.

- Para COMPOSTAGEM a busca foi realizada utilizando-se a seguinte sequencia de palavras chave: organic fraction of municipal solid waste AND solid waste processing AND composting (Fração orgânica de resíduos sólidos municipais + Processamento de Resíduos Sólidos + Compostagem). Considerando apenas as publicações do tipo artigos, artigos de revisão, resumos de conferencia. Foram adotados como termos a serem excluídos da busca capítulos de livro, Nitrogênio, esgoto não humano, metais pesados, metal pesado, resíduos industrial, lodo de esgoto, condições anóxicas, aterro sanitário, incineração e biodigestor anaeróbio. Ainda como critérios de exclusão, publicações voltadas a área de Imunologia, Matemática, Enfermagem, Farmácia, Medicina Veterinária, Química, Medicina, Sociologia, Engenharia Química e Ciência da Computação. Assim, chegou-se a um total de 135 artigos.

- Para VERMICOMPOSTAGEM a busca foi realizada utilizando-se a seguinte sequencia de palavras chave: organic fraction of municipal solid waste AND solid waste processing AND vermicomposting (Fração orgânica de resíduos sólidos municipais + Processamento de Resíduos Sólidos + Vermicompostagem). Considerando apenas as publicações do tipo artigos, artigos de revisão, resumos de conferencia. Foram adotados como termos a serem excluídos da busca Nitrogênio, esgoto não humano, metais 
pesados, metal pesado, resíduo industrial, lodo de esgoto, animais, condições anóxicas, aterro sanitário, incineração e biodigestor anaeróbio. Ainda como critérios de exclusão, publicações voltadas a área de Imunologia, Matemática, Enfermagem, Farmácia, Medicina Veterinária, Química, Medicina, Sociologia, Ciência da Computação e Engenharia Química. Assim, chegou-se a um total de 27 artigos.

- Para INCINERAÇÂO, a busca foi realizada utilizando-se a seguinte sequencia de palavras chave: municipal solid waste AND solid waste processing AND incineration (Resíduos sólidos municipais + processamento de resíduos sólidos + incineração), cujos tipos de publicação fossem artigos, artigos de revisão ou publicações em conferências, limitando a busca à área de medicina, física, saúde, neurociências. Foram consideradas as seguintes áreas de conhecimento: física e astronomia; ciência de materiais; química; medicina; engenharia; ciências ambientais; energia; engenharia química; negócios, gerenciamento e contabilidade; ciências biológicas e da agricultura. Foram excluídas publicações que contivessem os termos metais pesados, lixiviação, chumbo, cadmio, zinco, esgoto, não humano, cobre, pirolise, gaseificação, resíduo industrial, química, lodo de esgoto e vidro. Além disso, não foram consideradas publicações nas demais áreas. Desta maneira, foram encontrados 83 artigos.

- Para GASEIFICAÇÃO, foram consideradas a publicações que contivessem a seguinte combinação de termos de busca: municipal solid waste AND solid waste processing AND gasification (Resíduos Sólidos Municipais + processamento de resíduos sólidos + gaseificação); publicadas nas áreas bioquímica, genética e biologia molecular; engenharia química; química; ciências da computação; ciências ambientais; engenharia; imunologia e microbiologia; ciência de materiais; energia, matemática, física e astronomia, artes e humanidades e medicina. Ainda que fossem ar- 
tigos, artigos de revisão, documentos de conferência e documentos de revisão revistos. Foram excluídas publicações e que contivessem os termos incineração, pirólise, metais pesados, lodo de esgoto, esgoto, metano e chumbo. As áreas ciências da computação, biociências, matemática e artes e humanidades também foram desconsideradas. Chegou-se a um total de 25 artigos.

- Para PIRÓLISE, foram consideradas a publicações que contivessem a seguinte combinação de termos de busca: municipal solid waste AND solid waste processing AND pyrolysis (Resíduos Sólidos Municipais + processamento de resíduos sólidos + pirolise) em publicações que fossem do tipo artigo, artigos de revisão, documentos de conferencia e documentos de conferencia revistos. Foram consideradas publicações das áreas de biociências, matemática, ciências da computação e artes e humanidades. Ainda que contivessem os termos incineração, pirólise, lodo de esgoto, lodo, metais pesados, metano e chumbo. Foram encontrados 35 documentos.

- Para QUEIMA A PLASMA, foram consideradas a publicações que contivessem a seguinte combinação de termos de busca: municipal solid waste AND solid waste processing AND thermal plasma technology (Resíduos Sólidos Municipais + processamento de resíduos sólidos + Queima a Plasma) em publicações que fossem do tipo artigo, artigo de revisão, documento de conferencia, e documento de conferência revistos. Foram excluídas publicações que fossem de áreas como matemática, física, medicina, farmácia, imunologia, biociências, agricultura, engenharia química, enfermagem, artes e humanidades e ciências computacionais. Também foram excluídas publicações que contivessem termos como gaseificação, pirólise, metais pesados, lixiviação, chumbo, scanner de microscopia eletrônica, química analítica, lodo, toxicidade e adsorção. Termos e expressões selecionados entre as publicações obtidas na busca foram gerenciamento de re- 
síduos, incineração de resíduos, incineração, reciclagem, impacto ambiental, resíduos sólidos municipais, resíduos sólidos, tratamento de resíduos, combustão, poluição, disposição de resíduos, plasma, desenvolvimento sustentável, tratamento térmico, aquecimento, poluentes orgânicos, aplicações de plasma, eficiência energética, utilização de energia, tecnologia ambiental, emissões de gases, aterros sanitários, controle de poluição, ciclo de vida de produtos e rejeitos de incineração. Isso para publicações nas áreas de ciências ambientais; energia; engenharia; negócios, gestão e contabilidade; Terra e ciências planetárias; economia, métricas econômicas e finanças, ciências sociais e multidisciplinaridades. Foram encontrados 67 artigos.

- Para COMBUStíVEL DERIVAdO DE RESíduOS, foram consideradas a publicações que contivessem a seguinte combinação de termos de busca: municipal solid waste AND solid waste processing AND refuse derived fuel (Resíduos Sólidos Municipais + processamento de resíduos sólidos + Combustível Derivado de Resíduos) e que contivessem essa expressão. Publicações em revistas e jornais e previa de conferencias nas áreas de ciências ambientais; energia; engenharia química; engenharia; negócios, gestão e contabilidade; economia, métricas econômicas e finanças e ciências sociais. Foram excluídas aquelas realizadas nas áreas de química, medicina, física, agricultura, biociências, imunologia, ciências da computação, matemática e saúde. E utilizados termo de buscas para exclusão dióxido de carbono, digestão anaeróbia, aterro sanitário, hidrogênio, chumbo, cloro, resíduos industriais e publicações que estivessem em coreano. Foram encontradas 30 publicações.

- Por fim, ainda foram buscadas publicações para ATERRO SANITÁRIO, foram consideradas a publicações que contivessem a seguinte combinação de termos de busca: landfill AND municipal solid waste AND solid waste processing AND environmental 
impact (Resíduos Sólidos Municipais + processamento de resíduos sólidos + aterro sanitário + impacto ambiental). Os critérios para exclusão foram formados pelos termos, incineração, incineração de resíduos, compostagem, reciclagem, gerenciamento de resíduos. Compuseram a exclusão documentos do tipo livro e capitulo de livro. Bem como publicações nos idiomas croata, francês e sérvio. Ainda foram excluídas publicações nas áreas de biociências, imunologia, física, ciência da computação, matemática, artes e humanidades, enfermagem, psicologia e veterinária. Como inclusão, foram utilizados os termos lixiviação, lixiviado, poluição, concentração e composição, alterações no solo, poluição do solo, solo, monitoramento ambiental, lodo de esgoto, gerenciamento de resíduos sólidos e resíduos. Foram consideradas as publicações nas áreas de ciências ambientais; Terra e ciência planetária; engenharia; negócios; gestão e contabilidade; economia, métricas econômicas e finanças; agricultura e ciências sociais. E excluídas as publicações em matemática, energia, medicina e engenharia química. Desta forma, foram encontrados 48 artigos.

Além desta forma, após leitura dos artigos selecionados segundo estes critérios, algumas citações e referências contidas nos artigos também foram selecionadas segundo a aderência que porventura viessem a ter com esta pesquisa. Posteriormente, foram buscadas no Scielo, Lilacs e PubMed.

\subsection{A FERRAMENTA AHP}

O processo de tomada de decisão envolve a determinação de prioridades de acordo com graus de importância. Prioridades são determinadas e elencadas a partir de critérios de julgamento que consideram elementos como recursos empregados ou necessidades/atividades determinantes. Tais elemen- 
tos são avaliados conforme estes graus de importância. Desta forma, uma estrutura de hierarquia é estabelecida e o processo decisório deve atendê-la levando-se em consideração as alternativas existentes. Para auxiliar este processo, fazer comparações entre as alternativas dentro desta estrutura de prioridades (hierarquia) considerando todos os elementos acima apresentados, Saaty (1977) apresenta o método de escala por prioridades em estrutura hierárquica, que mais tarde passa a se chamar análise AHP.

O Método de Análise Hierárquica (Analytic Hierarchic Process, AHP) tem por objetivo orientar uma escolha considerando diversos critérios, utilizando 3 princípios do pensamento analítico. Tais princípios são descritos como a estruturação de hierarquias, onde a situação problema é descrita e fragmentada a fim de melhor organizar o processo de decisão. Tal etapa é determinante para que esta metodologia seja bem aplicada (Costa, 2002; Paiva e Bueno, SD).

O segundo princípio é a definição de prioridades a partir de comparações feitas entre as opções possíveis para a tomada de decisão. Tais comparações são sempre paritárias (Costa, 2002). Lima et al (2014), Azevedo et al (2009) corroboram esta afirmação.

A principal característica desta metodologia é considerar a subjetividade no processo decisório (PERELLES; MEDEIROS; GARCEZ, 2013), tratando-a de modo criterioso e sistematizado, principalmente quando não se tem dados estatísticos que auxiliem na decisão. Por fim, o principio final é a avaliação da consistência lógica utilizada nestas comparações (Costa, 2002).

Desta forma, pode-se descrever as etapas desta metodologia em fases descritas a partir do estabelecimento das hierarquias, onde são bem definidos e apresentados os critérios, subcritérios e alternativas envolvidas no processo de escolha. (SAATY, 1977, 2008; COSTA, 2002; PAIVA e BUENO, SD).

Posteriormente, passa-se então à coleta de dados ou julgamentos por parte de especialistas que dominem os produtos ou serviços presentes dentre as opções. Após a conclusão desta etapa, a síntese dos dados priorizados con- 
forme as alternativas apresenta um panorama geral que permite a tomada de decisão. Todavia, como tal metodologia considera a subjetividade humana no processo, é necessário que se avalie a consistência dos resultados obtidos, cuja finalidade é diminuir avaliações tendenciosas ou mal dimensionadas (COSTA, 2002; SAATY, 1977, 2008).

A escolha desta metodologia se mostra eficiente quando há várias alternativas com características diferentes e fatores determinantes intrínsecos que impactam a escolha. Há na literatura várias aplicações desta metodologia. Em especial, destaca-se MARCHEZETTI, KAVISKI e BRAGA (2011) ao aplica-la na escolha de tecnologias de tratamento de resíduos sólidos da Região Metropolitana de Curitiba. Já MARINS et al (2009) ressaltam a importância gerencial do processo decisório utilizando a metodologia AHP como uma importante ferramenta auxiliar capaz de sistematizar e flexibilizar às necessidades todas as opções de escolha envolvidas. Já PEREIRA et al (2012), PERELLES, MEDEIROS e GARCEZ (2013), SILVA et al (2013), SENA (2007), demonstram a versatilidade da aplicação da metodologia para várias realidades.

Lima et al (2014) também utilizaram a metodologia AHP para avaliar alternativas tecnológicas para tratamento de RSU, e apontam, como arranjos tecnológicos (combinações tecnológicas):

- Reciclagem combinada com aterro sanitário com geração de energia;

- Reciclagem combinada com uso de biodigestores ou usinas de compostagem e aterros sem geração de energia;

- Reciclagem com incineração e recuperação energética combinadas com aterro sanitário sem geração de energia.

Em ambos os casos, estes arranjos tecnológicos são indicado para cidades superiores a 250 mil habitantes, utilizando como critério de escolha a disponibilidade econômica para tal. E para cidades com população menor, o autor indica reciclagem combinada com aterro sem geração de energia. E para 
municípios de menor poder econômico a solução apontada seria a formação de consórcios.

Braga et al (2011) aplicam esta metodologia para escolha de tecnologias de tratamento de resíduos sólidos domiciliares (ou urbanos) para a Região Metropolitana de Curitiba e concluem que o custo de investimento não é um limitador a utilização de tecnologias para tratamento, pois os valores podem ser amortizados com a comercialização dos subprodutos que cada tecnologia pode produzir. Soluções consorciadas podem ocorrer entre municípios, reduzindo o impacto econômico inicial para a utilização das tecnologias escolhidas.

A análise multicritério AHP, embora muito versátil, possui limitações. Grandazol (2005) apresenta uma destas limitações como a aplicação indiscriminada da metodologia sem o devido conhecimento dos critérios utilizados. Tal limitação é amenizada com a participação de especialistas colaboradores.

Segundo Schmidt e Barbosa (2016), a subjetividade é uma limitação desta metodologia. Como forma de reduzirem avaliações tendenciosas que porventura possam existir, são aplicadas as análises de consistência, existentes na própria metodologia.

Outra desvantagem desta ferramenta é a necessidade do seu usuário em conhecer bem as alternativas e a situação contextualizada, a fim de elencar os critérios de escolha associados às possibilidades de escolha de modo hierarquizado, sob o risco de estruturar todo o processo decisório de modo equivocado. Tal procedimento inviabilizaria a análise. Desta forma, é imprescindível que o seu usuário conheça bem a situação, estruture a ferramenta corretamente e tenha uma visão holística a fim de viabilizar a escolha mais adequada às suas necessidades.

A revisão bibliográfica apresentou dados que acrescentam novas cores a aplicação da ferramenta, conforme pode ser verificada na tabela existente no Apêndice I. 
Outrossim, para uma maior acuidade na avaliação, optou-se por consulta a especialistas na área de tratamento de resíduos sólidos urbanos que colaboraram através do preenchimento de formulários (Apêndice II) a fim de aplicar a metodologia AHP. Tais especialistas colaboradores foram escolhidos e consultados sem que o pesquisador soubesse suas identidades e as respectivas formações, com o objetivo de não influenciar a pesquisa. 


\section{REFERENCIAL TEÓRICO}

\subsection{CARACTERIZAÇÃO DE RESÍDUOS SÓLIDOS}

A partir da promulgação da Política Nacional de Resíduos Sólidos, lei federal A lei 12.305 de 2 de agosto de 2010, tem-se o marco regulatório dos resíduos sólidos no Brasil. A Política Nacional de Resíduos Sólidos, define em seu art. 3ํㅜㄹ item XVI define resíduos sólidos como:

"material, substância, objeto ou bem descartado resultante de atividades humanas em sociedade, a cuja destinação final se procede, se propõe proceder ou se está obrigado a proceder, nos estados sólido ou semissólido, bem como gases contidos em recipientes e líquidos cujas particularidades tornem inviável o seu lançamento na rede pública de esgotos ou em corpos d'água, ou exijam para isso soluções técnica ou economicamente inviáveis em face da melhor tecnologia disponível;"

Neste artigo $3^{\circ}$, ainda traz definições importantes que pautam este trabaIho. Assim, tem-se os itens: II - área contaminada: local onde há contaminação causada pela disposição, regular ou irregular, de quaisquer substâncias ou resíduos; IV - ciclo de vida do produto: série de etapas que envolvem o desenvolvimento do produto, a obtenção de matérias-primas e insumos, o processo produtivo, o consumo e a disposição final; VII - destinação final ambientalmente adequada: destinação de resíduos que inclui a reutilização, a reciclagem, a compostagem, a recuperação e o aproveitamento energético ou outras destinações admitidas pelos órgãos competentes do Sisnama, do SNVS e do Suasa, entre elas a disposição final, observando normas operacionais específicas de modo a evitar danos ou riscos à saúde pública e à segurança e a minimizar os impactos ambientais adversos; VIII - disposição final ambientalmente adequada: distribuição ordenada de rejeitos em aterros, observando normas operacionais específicas de modo a evitar danos ou riscos à saúde pública e à segurança e a minimizar os impactos ambientais adversos; IX - geradores de resíduos sólidos: pessoas físicas ou jurídicas, de direito público ou privado, que geram resíduos sólidos por meio de suas atividades, nelas incluído o consumo 
e XV - rejeitos: resíduos sólidos que, depois de esgotadas todas as possibilidades de tratamento e recuperação por processos tecnológicos disponíveis e economicamente viáveis, não apresentem outra possibilidade que não a disposição final ambientalmente adequada.

Ainda nesta lei, em seu art. 6ํㅗㅇ são definidos os princípios que a regem. Dentre eles, podem ser apontados como relevantes para este trabalho, os itens I - a prevenção e a precaução; III - a visão sistêmica, na gestão dos resíduos sólidos, que considere as variáveis ambiental, social, cultural, econômica, tecnológica e de saúde pública; IV - o desenvolvimento sustentável; V - a ecoeficiência, mediante a compatibilização entre o fornecimento, a preços competitivos, de bens e serviços qualificados que satisfaçam as necessidades humanas e tragam qualidade de vida e a redução do impacto ambiental e do consumo de recursos naturais a um nível, no mínimo, equivalente à capacidade de sustentação estimada do planeta; VII - destinação final ambientalmente adequada: destinação de resíduos que inclui a reutilização, a reciclagem, a compostagem, a recuperação e o aproveitamento energético ou outras destinações admitidas pelos órgãos competentes do Sisnama, do SNVS e do Suasa, entre elas a disposição final, observando normas operacionais específicas de modo a evitar danos ou riscos à saúde pública e à segurança e a minimizar os impactos ambientais adversos; VIII - o reconhecimento do resíduo sólido reutilizável e reciclável como um bem econômico e de valor social, gerador de trabalho e renda e promotor de cidadania;

Este destaque se mostra relevante para a realização deste trabalho, a fim de ressaltar a necessidade da adoção de praticas e técnicas que possam ser adotadas para o tratamento adequado de resíduos sólidos, afim de que sejam alcançados os objetivos propostos nesta lei, os quais são definidos nos art. $7^{\circ}$. Neste artigo, destacam-se os itens I - proteção da saúde pública e da qualidade ambiental; II - não geração, redução, reutilização, reciclagem e tratamento dos resíduos sólidos, bem como disposição final ambientalmente adequada dos rejeitos; III - estímulo à adoção de padrões sustentáveis de produção e consumo de bens e serviços; IV - adoção, desenvolvimento e aprimoramento de tecnologias limpas como forma de minimizar impactos ambientais; $V$ - redu- 
ção do volume e da periculosidade dos resíduos perigosos; VI - incentivo à indústria da reciclagem, tendo em vista fomentar o uso de matérias-primas e insumos derivados de materiais recicláveis e reciclados; VII - gestão integrada de resíduos sólidos; VIII - articulação entre as diferentes esferas do poder público, e destas com o setor empresarial, com vistas à cooperação técnica e financeira para a gestão integrada de resíduos sólidos; IX - capacitação técnica continuada na área de resíduos sólidos; XIV - incentivo ao desenvolvimento de sistemas de gestão ambiental e empresarial voltados para a melhoria dos processos produtivos e ao reaproveitamento dos resíduos sólidos, incluídos a recuperação e o aproveitamento energético.

Corroborando a estes conceitos, soma-se a ABNT NBR 10.004: 2004 Classificação de Resíduos Sólidos. Nesta Norma, em seu item 3.1, define Resíduos Sólidos como:

"Resíduos nos estados sólido e semi-sólido, que resultam de atividades de origem industrial, doméstica, hospitalar, comercial, agrícola, de serviços e de varrição. Ficam incluídos nesta definição os lodos provenientes de sistemas de tratamento de água, aqueles gerados em equipamentos e instalações de controle de poluição, bem como determinados líquidos cujas particularidades tornem inviável o seu lançamento na rede pública de esgotos ou corpos de água, ou exijam para isso soluções técnica e economicamente inviáveis em face à melhor tecnologia disponível."

Ainda, nesta mesma norma, estão incluídos como resíduos não perigosos os elementos que constam em seu Apêndice $\mathrm{H}$.

\subsection{DISPOSIÇÃO FINAL DOS RSU}

Conforme o Panorama de Resíduos Sólidos da Abrelpe (2015), a população brasileira gerou 79,9 milhões de toneladas de resíduos sólidos urbanos, sendo que $90,8 \%$ do país é coberto pela coleta de resíduos. Estima-se que cerca de 7,3 milhões de toneladas ainda não sejam coletadas. Ainda atribui-se 
58,7\% (cerca de 42,6milhões de toneladas de RSU) tenham como disposição final os aterros sanitários. Todavia, questiona-se aqui o que significa disposição final adequada. A Lei 12.305/10, em seu art. 3ํitem VII explicita o significado de disposição final:

"disposição final ambientalmente adequada: distribuição ordenada de rejeitos em aterros, observando normas operacionais específicas de modo a evitar danos ou riscos à saúde pública e à segurança e a minimizar os impactos ambientais adversos" (grifo próprio).

Onde destaca-se o termo REJEITOS, o qual está descrito no item XV, da mesma lei, onde:

"resíduos sólidos que, depois de esgotadas todas as possibilidades de tratamento e recuperação por processos tecnológicos disponíveis e economicamente viáveis, não apresentem outra possibilidade que não a disposição final ambientalmente adequada;"

Segundo esta publicação, a geração de resíduos no país para o ano foi de $218.874 \mathrm{t} / \mathrm{dia}$, correspondendo a $1,071 \mathrm{Kg} / \mathrm{hab}$ dia. Sendo coletadas $198.750 \mathrm{t} / \mathrm{dia}$, ou $0,972 \mathrm{Kg} / \mathrm{hab}$ dia.

\begin{tabular}{|c|c|c|c|c|c|c|c|c|c|c|c|c|}
\hline \multirow{2}{*}{ Região } & \multicolumn{2}{|c|}{ Norte } & \multicolumn{2}{|c|}{ Nordeste } & \multicolumn{2}{|c|}{ Centro-Oeste } & \multicolumn{2}{|c|}{ Sudeste } & \multicolumn{2}{|c|}{ Sul } & \multicolumn{2}{|c|}{ Brasil } \\
\hline & 2014 & 2015 & 2014 & 2015 & 2014 & 2015 & 2014 & 2015 & 2014 & 2015 & 2014 & 2015 \\
\hline Sim & 239 & 258 & 767 & 884 & 175 & 200 & 1.418 & 1.450 & 1.009 & 1.067 & 3.608 & 3.859 \\
\hline Não & 211 & 192 & 1027 & 910 & 292 & 267 & 250 & 218 & 182 & 124 & 1.962 & 1.711 \\
\hline Total & \multicolumn{2}{|c|}{450} & \multicolumn{2}{|c|}{1.794} & \multicolumn{2}{|c|}{467} & \multicolumn{2}{|c|}{1.668} & \multicolumn{2}{|c|}{1.191} & \multicolumn{2}{|c|}{5.570} \\
\hline
\end{tabular}

Tabela 1 - Quantidade de Municípios brasileiros com iniciativa de coleta seletiva. (ABRELPE,2015).

A tabela 1 apresenta a quantidade de municípios que trabalham de alguma forma com a segregação de resíduos entre os anos de 2014 e 2015, conorma suas respectivas regiões do país. Ainda, segundo este relatório, há a persistência de lixões (irregulares) e aterros controlados, para onde são encaminhados os resíduos sólidos sem tratamento sendo que $17,2 \%$ dos resíduos 
vão para lixões, $24,1 \%$ para aterros controlados e 58,7\% para aterros sanitários.

Com a publicação da PNRS, os municípios e estados teriam um prazo de 4 anos para a extinção dos lixões, quando deveriam existir exclusivamente aterros sanitários. Contudo, foi aprovado no Senado o projeto de lei no 425 , de 2014, que seguiu para votação na Câmara dos deputados em 08/07/2015 . Tal projeto altera a PNRS de modo a permitir a adequação de estados e municípios (extinção dos lixões) ate o ano de 2021. A tabela 2 apresenta as formas de disposição final adotada pelos municípios no ano de 2015. Na tabela 3, podese observar as formas de disposição final adotadas por 3 cidades de relevância econômico-politica no pais (Rio de Janeiro, São Paulo e Brasília).

\begin{tabular}{|c|c|c|c|c|c|c|c|}
\hline \multirow{2}{*}{ Disposição Final } & \multicolumn{6}{|c|}{2015 -Regiões e Brasil } & \multirow{2}{*}{$\begin{array}{c}\text { Brasi } \\
2014\end{array}$} \\
\hline & Norte & Nordeste & Centro-Oeste & Sudeste & Sul & Brasil & \\
\hline Aterro Sanitário & 97 & 456 & 165 & 820 & 706 & 2.244 & 2.236 \\
\hline Aterro Controlado & 110 & 504 & 148 & 646 & 366 & 1.774 & 1.775 \\
\hline Lixão & 243 & 834 & 154 & 202 & 119 & 1.552 & 1.559 \\
\hline BRASIL & 450 & 1.794 & 467 & 1.668 & 1.191 & 5.570 & 5.570 \\
\hline
\end{tabular}

Tabela 2 - Quantidade de Municípios por Tipo de Disposição Final Adotada- 2015 (ABRELPE, 2015).

A partir do Panorama de Resíduos Sólidos da ABRELPE (2015), tem-se a seguinte tabela:

\begin{tabular}{|c|c|c|c|c|c|c|c|}
\hline Ente da Federação & $\begin{array}{c}\text { População } \\
\text { em } 2015\end{array}$ & $\begin{array}{c}\text { RSU } \\
\text { Gerado } \\
\text { (T/dia) }\end{array}$ & $\begin{array}{l}\text { RSU Coletado } \\
\text { (kg/ hab dia) }\end{array}$ & $\begin{array}{c}\text { RSU } \\
\text { Coletado } \\
\text { (T/dia) }\end{array}$ & $\begin{array}{c}\text { Aterro } \\
\text { Sanitário }\end{array}$ & $\begin{array}{c}\text { Aterro } \\
\text { Controlado }\end{array}$ & Lixão \\
\hline Rio de Janeiro & 16.550 .024 & 22.213 & 1.323 & 21.895 & 15.021 & 4.686 & 2.188 \\
\hline São Paulo & 44.396 .484 & 62.585 & 1.400 & 62.156 & 47.985 & 9.262 & 4.909 \\
\hline Distrito Federal & 2.914 .830 & 4.653 & 1.565 & 4.561 & 0 & 4.561 & 0 \\
\hline
\end{tabular}

Ressalta-se que em grande parte, a coleta de resíduos sólidos urbanos realizada no país é indiferenciada, inviabilizando alguns tratamentos que responderiam a legislação de modo a reduzir o volume dos resíduos encaminhados aos aterros, bem como a reduzir os impactos causados pelos resíduos sólidos putrescíveis. A titulo de exemplo quanto a viabilidade de segregação de 
resíduos na fonte geradora, Puyuelo et al. (2013) relatam que que $100 \%$ dos resíduos sólidos municipais na Catalunha são segregados na geração, antes da coleta.

Segundo Vital et al (2014) ressalta os custos da disposição inadequada de RSU e do principio que norteia a legislação, que o de desenvolvimento sustentável, reforçando a ideia de valorização dos resíduos. Tal fator está intimamente associado com as formas de tratamento a serem dadas aos resíduos.

Vital et al (2014), apresenta modelagem para apresentar o custo de investimento necessário para a extinção dos lixões no Brasil até o ano de 2019, considerando valores estimados de disposição inadequada de resíduos sólidos para o ano de 2012, o custo de implementação de aterro (conforme critérios do autor - aterro pequeno para 100 t/dia; aterro médio I para 500 t/dia; aterro médio II para 1000 t/dia e aterro grande para 2000 t/dia de RSU).

Além desses, utilizou o parâmetro de distribuição espacial dos RSU a partir da distribuição espacial da população brasileira. O autor chegou aos seguintes valores (Tabela 4):

\begin{tabular}{lrccc}
\hline & $\begin{array}{c}\text { Grande - } \\
\mathbf{2 . 0 0 0} \mathbf{t} / \mathbf{d i a}\end{array}$ & $\begin{array}{c}\text { Médio I }- \\
\mathbf{1 . 0 0 0 ~ t / d i a *}\end{array}$ & $\begin{array}{c}\text { Médio II - } \\
\mathbf{5 0 0 ~ t / d i a *}\end{array}$ & $\begin{array}{c}\text { Pequeno- } \\
\mathbf{1 0 0} \mathbf{t} / \mathbf{d i a}\end{array}$ \\
\hline Pré-implantação & 4.065 .461 & 2.032 .730 & 1.355 .153 & 608.087 \\
Implantação & 18.169 .781 & 9.084 .890 & 6.056 .593 & 2.669 .178 \\
Operação & 461.494 .052 & 230.747 .026 & 153.831 .350 & 45.468 .163 \\
Encerramento & 6.488 .889 & 3.244 .444 & 2.162 .963 & 486.667 \\
Pós-encerramento & 35.575 .984 & 17.787 .992 & 11.858 .661 & 3.212 .354 \\
\hline Total & $\mathbf{5 2 5 . 7 9 4 . 1 6 7}$ & $\mathbf{2 6 2 . 8 9 7 . 0 8 3}$ & $\mathbf{1 7 5 . 2 6 4 . 7 2 2}$ & $\mathbf{5 2 . 4 4 4 . 4 4 9}$ \\
\hline
\end{tabular}

Tabela 4 - adaptado de Vital (2014).

Conforme este panorama apresentado percebe-se a importância do tratamento e da disposição final adequada dos resíduos sólidos urbanos. Os custos de pós-encerramento estão vinculados com o monitoramento das áreas contaminadas. Ressalta-se que nessa fase do projeto, não há mais a exploração econômica, transformando o empreendimento num passivo ambiental. 
Assim, para a realidade brasileira, há ainda uma necessidade de implantação de dispositivos que possam atender e corrigir as demandas de geração de RSU. Lima et al (2014) se referiram a reciclagem e as possibilidades de uso de aterro sanitário para recuperação energética.

Do ponto de vista da gestão dos resíduos sólidos, é preciso integrar as suas diferentes etapas, desde a acumulação até a destinação final, ao planejamento urbano a fim de reduzir os impactos da operação, encerramento e pósencerramento das atividades dos aterros sanitários, bem como permitir a reurbanização das suas áreas usadas. (MANNARINO et al,2016).

Nesse sentido, é necessário informar que a Fundação Nacional da Saúde (FUNASA) possui o Departamento de Engenharia de Saúde Pública (Densp) cujo objetivo é fomentar soluções em saneamento a fim de prevenir doenças, através de financiamento de ações de universalização do abastecimento de água, esgotamento sanitário e gestão de resíduos Sólidos Urbanos. Desta forma, tais ações buscam minimizar os impactos ambientais, bem como, evitar a proliferação de vetores. Cabe salientar que são foco destas ações os municípios cuja população seja igual ou inferior a 50 mil habitantes. (FUNASA, 2017a)

A FUNASA ressalta que recursos da União são repassados aos municípios que possuem o Plano Municipal de Gestão Integrada de Resíduos Sólidos (PMGIRS). Além disso, a instituição possui o Programa de Resíduos Sólidos, o qual prevê investimentos voltados à implementação e de melhorias em sistemas integrados de Gerenciamento e Resíduos Sólidos Urbanos. (FUNASA, 2017b) 


\subsubsection{Lixão ou Vazadouro}

Conforme descrito por Lanza e Carvalho (2006), lixão ou vazadouro é qualquer local onde ocorra a disposição final dos resíduos inadequada sem quaisquer cuidados ou estruturas apropriadas para a contenção ou tratamento dos RSU. É caracterizado pela presença de vetores (ratos, baratas, etc), pelo odor de matéria orgânica em decomposição, presença de urubus, chorume. Como consequências há emissões atmosféricas, em destaque para gases de efeito estufa como o $\mathrm{CH}_{4}$ e $\circ \mathrm{CO}_{2}$, percolado ou chorume contaminando solo, camadas subterrâneas, podendo alcançar o lençol freático.

Geralmente os lixões servem como sustento para catadores e cidadãos em estado de completa vulnerabilidade social. A exemplo do lixão de Gramacho, situado no município de Duque de Caxias, recebia os RSU da região metropolitana do Rio de Janeiro (Rio de Janeiro, Duque de Caxias, São João de Meriti, Queimados e Belford Roxo). Segundo Bastos e Magalhães (2016) eram cerca de $15 \mathrm{mil}$ pessoas que dependiam diretamente do lixão como meio de sustento, chegando a recuperar cerca de 200 toneladas de recicláveis por dia.

A reinserção destes cidadãos na sociedade com atividades que possam lhes garantir o sustento é uma questão de saúde publica. Este custo não está inserido nos projetos de implantação de aterros sanitários, mas são questões sensíveis que devem ser consideradas. Como ocorreu com Gramacho, não é incomum encontrar outros em situação semelhante pelo país.

\subsubsection{Aterro Controlado}

Trata-se de uma técnica de contenção dos RSU, cujos parâmetros de construção e funcionamento são regidos pela ABNT NBR 8849/1985. Nesta realidade, os RSU ficam contidos, embora ainda ocorram vazamentos de percolado devido a falta de impermeabilização do solo; a principal característica é o recobrimento dos resíduos com camada de material inerte ou terra. 
No projeto de aterro controlado, a norma preconiza que exista a quantidade estimada de RSU recebidos por dia e por ano, capacidade e a previsão de uso de acordo com a capacidade e qual o destino da área após os encerramentos das atividades. A norma não menciona o monitoramento após o fim das atividades do aterro. Segundo Lanza e Carvalho (2006), o aterro controlado é preferível aos lixões, embora não seja uma solução ambientalmente adequada.

\subsubsection{Aterro Sanitário}

Regido pela ABNT NBR 8419/1992 - Apresentação de projetos de aterros sanitários de resíduos sólidos urbanos - e pela ABNT NBR 13896/1997 Aterros de resíduos não perigosos - Critérios para projeto, implantação e operação - o aterro sanitário é uma obra de engenharia com previsão de funcionamento de no mínimo 10 anos de operação e consequentes mínimos 10 anos de monitoramento, que responde pelo recebimento, tratamento, confinamento adequado dos RSU. Projetado para receber os resíduos que, depois de esgotadas as possibilidades de tratamento, passem a ser denominados rejeitos.

Grosso modo, não deveria existir o tratamento, visto que apenas os rejeitos deveriam ser encaminhados (aumentando a vida útil devido a redução do volume nele inserido). Todavia, como não há a segregação dos resíduos na fonte geradora de maneira ostensiva, ocorre a contaminação dos RSU recicláveis com matéria orgânica, embora a legislação responsabilize os consumidores a segregar os resíduos antes de serem coletados (BRASIL, 2010b). Tal condição também fica evidenciada pela presença de matéria orgânica, que segundo ABRELPE (2015a) está presente na massa de RSU em 51,4\% da composição total. Esta matéria orgânica é a responsável pelas emissões atmosféricas, biogás (com poder calorifico) e pelo chorume.

Em aterros sanitários devem estar presentes sistemas de impermeabilização da base e laterais, sistema de recobrimento diário e o final, coleta e dre- 
nagem de percolado, coleta e tratamento de gases de aterro (biogás), drenagem superficial, tratamento de chorume e sistema de monitoramento (Lanza e Carvalho, 2006). 


\subsection{TECNOLOGIAS DISPONÍVEIS DE TRATAMEN- TO DE RSU}

As tecnologias disponíveis para tratamento de resíduos sólidos urbanos, também conhecidos como resíduos sólidos municipais, foram agrupadas de acordo com a natureza dos processos envolvidos. Desta forma, foram agrupados em tratamentos biológicos (biodigestores, co-digestão, compostagem e vermicompostagem) e tratamentos térmicos (incineração, pirolise, gaseificação e plasma).

\subsubsection{Tratamento biológico}

O tratamento biológico de RSU pode ser compreendido como a estabilização dos elementos biodegradáveis nele presentes através da ação de microrganismos (FEAM, 2012). Somente a matéria orgânica putrescível é afetada por este tipo de tratamento. Existem as seguintes formas de tratamento biológico:

- Biodigestão;

- Co-digestão;

- Compostagem;

- Vermicompostagem.

A biodigestão e a co-digestão ocorrem nos chamados biodigestores anaeróbios. Já a compostagem é um processo aeróbio e está relacionada com a mistura dos resíduos com o solo e microrganismos presentes decompõem estes resíduos, e a vermicompostagem, é a associação da compostagem com anelídeos (minhocas). 


\subsubsection{Biodigestores}

O biodigestor anaeróbio é um equipamento capaz de, por ação de bactérias, degradar matéria orgânica complexa em substâncias mais simples. Tal processo ocorre sem a presença de oxigênio. "Um biodigestor nada mais é que um reator químico em que as reações químicas têm origem biológica" (CASTANHO; ARRUDA, 2008).

Existem duas formas de se utilizar biodigestores: a contínua e por batelada. Este último é designado para pequenos volumes ou resíduos produzidos de maneira intermitente, não sendo indicado para necessidades maiores de tratamento de resíduos. Dentre os modelos mais utilizados, ressaltam-se 3 tipos de biodigestor anaeróbios: o modelo Indiano (requer um custo maior de implantação), o modelo chinês (o mais simples) e o canadense ou de manta de PVC (mais indicado para grandes volumes de resíduos). Quanto ao tipo continuo, "os tipos de biodigestores mais usados são o Canadense, o Indiano e o Chinês." (CASTANHO; ARRUDA, 2008)

A oxidação de matéria orgânica em presença de gás oxigênio tem como produto final água e gás carbônico. Quando a quantidade de oxigênio é pouca ou variável, pode ocorrer a produção de monóxido de carbono. E quando não há presença de oxigênio durante o processo de oxidação, surgem outros compostos. Dentre estes o gás metano é o principal produto final do processo (biogás). A parte resíduos não gasosa possui potencial (bio)fertilizante.

"Qualquer resíduo orgânico não esterilizado, sob condições anaeróbias, faculta no desenvolvimento de bactérias anaeróbias, as quais atacam os sólidos voláteis (exceto a lignina) da matéria orgânica decompondo-a, tendo como produtos finais, basicamente, metano e dióxido de carbono (biogás)." (SILVA; SILVA, 2012)

Alguns autores (CASTANHO; ARRUDA, 2008; VERMA,2002; KIGOZI; ABOYADE; MUZENDA, 2014) definem o processo de biodigestão anaeróbica em três fases: Hidrolise - fase onde macromoléculas complexas são digeridas 
através de enzimas, dando origem a compostos simples; Acetogênese - fase onde carboidratos e lipídios são convertido em ácido acético ou acetatos; Metanogênese - fase onde um terceiro grupo de bactérias produz metano a partir do ácido acético. As bactérias metanogênicas são methanobacterium, methanobacillus, methanococcus e methanosarcina (VERMA, 2002).

Já Barcelos (2009) separa o processo em 4 estágios. Hidrólise, Acidogênese, Acetogênese e Matanogênese. $O$ acréscimo da fase de acidogênese é dado pela formação de outros compostos ácidos intermediários (tais como ácidos graxos) que resultarão posteriormente em ácido acético. Contudo, ressalta que devido o fato do ph desta fase chegar a 6,5, ocorrem a solubilização de metais, embora possa ocorrer a formação de amônia $\left(\mathrm{NH}_{3}\right)$, gás sulfídrico $\left(\mathrm{H}_{2} \mathrm{~S}\right)$ que podem interromper o próximo estágio (metanogênese). Caso ocorra acidificação prolongada, recomenda-se a correção do $\mathrm{pH}$, com cautela para evitar-se a saponificação, fator que pode reduzir a formação de acetatos, conforme informa Kigozi, Aboyade e Muzenda (2014).

Há fatores que influenciam o funcionamento do biodigestor. $\mathrm{O} p H$ e a temperatura são elementos determinantes para a produção de gás, assim como a degradação da matéria orgânica. Segundo Verma (2002) o pH ótimo para a fase metanogênica fica entre 7,2 e 8,2. Já Kigozi, Aboyade e Muzenda (2014) apontam pH entre 7 e 8,5 como ideais para a formação de metano, além de afirmar que o processo para quando o $\mathrm{pH}$ cai a 6,5 ou menos.

Conforme explicam Kigozi, Aboyade e Muzenda (2014), pode-se classificar o processo de biodigestão quanto a temperatura da seguinte forma: - Psicrofílico - fermentação em temperaturas abaixo de $30^{\circ} \mathrm{C}$; - Mesofílico - fermentação em temperaturas entre $30^{\circ} \mathrm{C}$ e $40^{\circ} \mathrm{C}$, - Termofílico - fermentação em temperaturas entre $50^{\circ} \mathrm{C}$ e $60^{\circ} \mathrm{C}$. Contudo, ainda segundo Kigozi, Aboyade e Muzenda (2014), quando a temperatura chega a $10^{\circ} \mathrm{C}$ ou menos o processo para. Desta forma, o autor recomenta como temperatura ideal $35^{\circ} \mathrm{C}$. 
Outros fatores que vão influenciar no processo de formação de biogás e biofertilizante. A partir da fermentação dos resíduos são a relação Carbono e Nitrogênio, os Sólidos Totais, Sólidos Voláteis, a Demanda Química de Oxigênio (DQO), a relação de água e a parte sólida além da taxa de entrada de carga de resíduos - esta é intimamente relacionada ao dimensionamento do biodigestor, juntamente com o tempo de permanência dos resíduos.

Estes são parâmetros que ajustam a quantidade de biogás gerado e definem efetivamente a quebra dos compostos complexos e a inativação de organismos patogênicos presentes na carga orgânica. $O$ tamanho das partículas do substrato precisa estar entre $2 \mathrm{~mm}$ e $100 \mathrm{~mm}$ como faixa de excelência para a produção de biogás.

Vemos com Verma (2002) que a relação Carbono/Nitrogênio ideal fica entre 20:1 e 30:1. Relações maiores geram um consumo maior de nitrogênio por parte das bactérias metanogênicas, e desta forma, uma menor produção de gás. Relações menores geram maiores concentrações de amônia e aumentar 0 $\mathrm{pH}$ para 8,5 ou mais, parando o processo devido a toxicidade para as bactérias metanogênicas.

Kigozi, Aboyade e Muzenda (2014) especificam Sólidos Totais (ST) como o material pesado na amostra de material colhido após ter sido aquecido a 105ํㅡ por 48 horas. Sólidos Voláteis como a fração orgânica presente nos ST que é removida da amostra após aquecida a $550^{\circ} \mathrm{C}$ por 24 horas. A DQO ou Demanda Química de Oxigênio é o equivalente a quantidade de oxigênio presente no substrato e que serve como indicador da quantidade de matéria orgânica degradável na amostra.

Ainda, segundo Kigozi, Aboyade e Muzenda (2014), a taxa de entrada da carga orgânica ( $\mathbf{T x}$ ) é dada pela fórmula, onde $\mathbf{Q}$ é vazão de entrada ( $\left.\mathrm{m}^{3} / \mathrm{dia}\right)$; S é a concentração de sólidos voláteis presentes na carga orgânica de entrada $\left(\mathrm{Kg} / \mathrm{m}^{3}\right)$ e $\mathbf{V}$ é o volume do biodigestor $\left(\mathrm{em} \mathrm{m}^{3}\right)$. (Tradução própria) 
Cabe ressaltar que o processo de biodigestão necessita inicialmente uma semeadura com as bactérias envolvidas no processo. Para isso, utiliza-se esterco fresco para inoculação inicial do substrato.

"A adição de esterco aos resíduos sólidos orgânicos modifica as características do processo. O esterco possui alta quantidade de microrganismos, alta umidade e $\mathrm{pH}$ próximo da neutralidade, portanto as características do esterco são complementares às dos resíduos sólidos que, no geral, possuem $\mathrm{pH}$ baixo e pouca quantidade de microorganismos. Um problema advindo da digestão de esterco com a fração orgânica é com relação à tipologia da matéria orgânica. Caso a fração orgânica possua altas concentrações de proteínas pode ocorrer inibição da digestão anaeróbia pela amônia, principalmente se o percolado for recirculado. "(BARCELOS, 2009)

Em sua publicação, Rao (2004) relata que iniciou o processo usando $15 \%$ do volume do biorreator de esterco fresco, atingindo a relação de $65 \mathrm{~g}$ de ST/I como a relação ideal para o processo ocorrer com processo mesofílico de fermentação.

\section{Características da biodigestão anaeróbia}

O ponto mais alto de eficiência térmica em três principais grupos bacterianos: psicrofílicos (de 15 a $25^{\circ} \mathrm{C}$ ), mesofílicos (de 37 a $42^{\circ} \mathrm{C}$ ) e termofílicos (entre 50 e $60^{\circ} \mathrm{C}$ ). A maior parte das bactérias da metanogênese são mesofílicas (ótimo entorno de $39^{\circ} \mathrm{C}$ ) e trabalham em uma temperatura de aproximadamente $39^{\circ} \mathrm{C}$. Variações nessa temperatura podem até anular quase que completamente a produção de biogás de um sistema. A partir de temperaturas inferiores a $15^{\circ} \mathrm{C}$ a biodigestão para.

O pH segue pelo mesmo princípio da temperatura. Cada grupo de bactérias possuem seu ponto ideal de acidez. Nas fases da hidrólise e da acidogênese o pH ideal fica em torno de 5,2 à 6,3. Já na acetogênese e metanogênese o pH ideal fica entre 6,5 à 8 . 
No final de 2004, a Europa tinha disponível uma capacidade de digestão anaeróbia de 2.553.000 t/ano para tratamento de resíduos orgânicos domiciliares (decorrente de 86 plantas com capacidade média de 29.686 t/ano), sendo 37 plantas na Alemanha (totalizando uma capacidade de 683.605 t/ano); no entanto, estava na Espanha a maior capacidade instalada (818.000 t/ano). As instalações na Alemanha possuíam, à época, capacidade média de 18.500 t/ano, enquanto que as instalações mais recentes nos arredores de Barcelona (Espanha) tratavam em média 63.000 t/ano de orgânicos presentes no RSU (CEMIG GT e FEAM, 2009).

As principais tecnologias comerciais existentes para a digestão anaeróbia de RSU são denominadas: VALORGA (francesa), DRANCO (belga), BTA (alemã), WAASA (finlandesa), KOMPOGÁS (suiça) e LINDE (suiça), as quais estão patenteadas e implantadas em diversos países.

Observam-se ainda problemas técnicos nos digestores das tecnologias comerciais, principalmente no que tange aos aspectos operacionais, tais como a agitação do material, acumulação de inertes, criação de caminhos preferenciais e zonas mortas (DEFLOR, 2009 apud CEMIG GT e FEAM, 2009).

Os sistemas de digestão anaeróbia se classificam também quanto ao teor de sólidos totais (ST) na massa de alimentação do reator (REICHERT, 2005 apud CEMIG GT e FEAM, 2009):

- Baixo teor de sólidos (ou úmidos): ST < 15\% - implica maior volume do reator, consumo de água e geração de efluentes;

- Médio teor de sólidos: $15 \%<\mathrm{ST}<20 \%$;

- Alto teor de sólidos (ou secos): $22 \%<\mathrm{ST}<40 \%$-implica menor volume do reator, equipamentos mais caros (bombas e outros). (TORRES; PEDROSA; MOURA, 2012)

O biogás formado na digestão anaeróbia é uma mistura gasosa composta tipicamente por $60 \%$ de $\mathrm{CH}_{4}, 35 \%$ de $\mathrm{CO}_{2}$ e $5 \%$ de outros gases como $\mathrm{H}_{2}$, $\mathrm{N}_{2}, \mathrm{H}_{2} \mathrm{~S}, \mathrm{CO}, \mathrm{O}_{2}$ e aminas voláteis. Dependendo da eficiência do processo, o 
biogás chega a conter entre 40 e $80 \%$ de metano (FIGUEIREDO, 2007; CEMIG GT e FEAM, 2009).

O sistema de controle dos efluentes atmosféricos, procedentes da queima do biogás, deve estar dotado de equipamentos de monitoramento contínuo, no mínimo, para os parâmetros vazão, $\mathrm{CO}_{2}$ e $\mathrm{O}_{2}$; e periódico para os parâmetros $\mathrm{CO}, \mathrm{NOx}, \mathrm{SOx}$ e $\mathrm{CH}_{4}$. A avaliação das emissões deve contemplar os parâmetros e frequências estabelecidos pela Resolução CONAMA no 382/2006 e no 436/2011 que estabelecem os limites máximos de emissão de poluentes atmosféricos para fontes fixas.

\subsection{Biodigestor Tipo Chinês}

O biodigestor modelo Chinês (continuo em pequenas quantidades) foi desenvolvido voltado para as pequenas propriedades rurais. É um modelo de peça única, construído em alvenaria e enterrado no solo, para ocupar menos espaços. Este modelo tem o custo mais barato em relação aos outros, pois sua cúpula também é feita em alvenaria. ( $<8 \%$ de ST) (TORRES; PEDROSA; MOURA, 2012).

\subsection{Biodigestor Tipo Indiano}

O biodigestor Indiano (contínuo) tem sua cúpula geralmente feita de ferro ou fibra. Nesse tipo de biodigestor o processo de fermentação acontece mais rápido, pois aproveita a temperatura do solo que é pouco variável, favorecendo a ação das bactérias. Ocupa ainda pouco espaço e a construção por ser subterrânea, dispensa o uso de reforços, tais como cintas de concreto. $(<8 \%$ de ST).

\subsection{Biodigestor Tipo Canadense}

O biodigestor modelo Canadense ou de marinha ou tubular (contínuo) é um modelo tipo horizontal, apresentando uma caixa de carga em alvenaria e 
com a largura maior que a profundidade, possuindo, portanto, área maior de exposição ao sol, o que possibilita numa grande produção de biogás e evitando o entupimento. Durante a produção de gás, a cúpula do biodigestor infla porque é feita de material plástico maleável (PVC), podendo ser retirada. O maior empecilho deste equipamento é o alto custo da cúpula (TORRES; PEDROSA; MOURA, 2012).

O uso de biodigestores é uma realidade apresentada e fomentada pela EMBRAPA desde a década de 80. Seja para a geração de biogás, seja para a produção de biofertilizantes, sua aplicação se apresenta como uma alternativa para a geração de energia em localidades remotas ou para uma adequação a legislação quanto ao tratamento de resíduos sólidos, agropecuários ou resíduos de saneamento básico.

A EMBRAPA, Empresa Brasileira de Pesquisa Agropecuária, se divide em várias unidades, centrais e descentralizadas. A unidade de pesquisa que desenvolve projetos com biodigestores é a unidade descentralizada localizada em Brasília, chamada de Embrapa Meio Ambiente. Além disso, a empresa mantém um projeto cujo objetivo é a produção e a troca de informações em parceria com a Itaipu Binacional, conhecida como Rede Biogásfert.

"O Plano Setorial de Mitigação e de Adaptação às Mudanças Climáticas para a Consolidação de uma Economia de BaixaEmissão de Carbono na Agricultura, também denominado Plano ABC (Agricultura de Baixa Emissão de Carbono),é um dos Planos Setoriais elaborados de acordo com o artigo 3을 Decreto 7.390/2010 e tem a finalidade de organizaro planejamento das ações a serem realizadas para adoção das tecnologias sustentáveis de produção selecionadaspara responder aos compromissos assumidos pelo país de redução de emissão de GEE no setor agropecuário.." (BRASIL, 2012)

O Banco Central possui uma linha de crédito (Resolução BACEN no 3.896 de 17/08/10) para fomento para a implementação de ações e projetos que visam a mitigação de impactos oriundos da geração de gases do efeito estufa.

Sendo parte fundamental deste processo de combate ao aquecimento global, os biodigestores apresentam-se como uma ferramenta crucial no que tange ao tratamento de resíduos (sólidos urbanos, agropecuários, de efluen- 
tes), a geração de energia com o aproveitamento do biogás, além da produção de fertilizante como resultado.

O biogás é uma mistura de gases oriundos da fermentação dos resíduos, que digeridos por bactérias presentes no solo e no trato digestório de ruminantes, são produzidos na ausência do Oxigênio. Desta maneira, o processo de degradação destes resíduos ocorre em três etapas: hidrólise, acetogênese e metanogênese.

A última etapa é a fundamental para o processo de produção de metano. E determinante, pois é extremamente sensível a mudanças de temperatura e ph.

"A temperatura e o pH interferem na produção de biogás pois uma temperatura abaixo de $10{ }^{\circ} \mathrm{C}$ a fermentação é fraca e acima de $65^{\circ} \mathrm{C}$ ela é nula. Em meio ácido a atividade enzimática é anulada e num meio alcalino produz anidrido sulforoso e hidrogênio. A digestão pode efetuar-se entre o $\mathrm{pH}$ de 6,6 a 7,6. A presença de materiais tóxicos, detergentes e outros produtos químicos devem ser evitados. A equivalência energética do biogás em um metro cúbico é: 1.5 metros cúbicos de gás de cozinha; 0.52 a 0,60 litros de gasolina; 0.9 litros de álcool; $1.43 \mathrm{kWh}$ de eletricidade; $2.7 \mathrm{Kg}$ de lenha. A Relação Carbono/Nitrogênio $(C / N)$ é um fator muito importante a considerar para se determinar o tempo que o material levará para se decompor, quanto maior esta relação, mas lenta será a decomposição. Condição ótima para o processo está em torno de 30/1." (SILVA; SILVA, 2012)

O uso de biodigestores anaeróbios tem se apresentado economicamente viável no que diz respeito ao tratamento de resíduos dos processos de agropecuária. No Brasil, na China, na Índia, Polônia, Alemanha, entre outros países, a utilização de modelos para pequenas propriedades rurais se mostra como alternativa viável a manutenção das necessidades individuais dos moradores das propriedades.

Quanto a produção de biogás, cerca de $70 \%$ de sua composição é formada pelo gás metano, cujo poder calorífico atinge os $5500 \mathrm{Kcal}$, o qual corresponde a $1,5 \mathrm{~m}^{3}$ de GLP; $7 \mathrm{kw} / \mathrm{h}$ de eletricidade, 0,81 de gasolina; $2,7 \mathrm{~kg}$ de madeira; 1,3 I de álcool e 1,4 kg de carvão vegetal (ALVES et al., 2014). 
Todavia, esse potencial energético pode ser ampliado significativamente quando o biogás é purificado (91\%), retirando-se o gás sulfídrico $\mathrm{H}_{2} \mathrm{~S}$ e 0 gás carbônico $\left(\mathrm{CO}_{2}\right)$ através de utilização de membrana filtrante. A um custo de $\mathrm{U} \$$ 0,35. (SAMSON, AKINWALE, 2014).

Como opção de tratamento de resíduos, existem vários trabalhos indicando o uso de resíduos sólidos municipais como insumo para a geração de gás. Para tanto, é fundamental a mistura de resíduos sólidos com água em presença de um misturador. É recomendado um mínimo de 1 parte de resíduo sólidos para 2 partes de água para que a geração de gás seja feita.

SOUZA et al (2010) validou o uso de resíduos da bananicultura como insumo para a produção de biogás. Ele utilizou a espécie Musa cavendish (banana nanica) na forma de cascas, engaço (parte resistente onde se forma o cacho), folhas e pseudocaule. Verificou-se que apenas o engaço não deve ser utilizado devido a alta concentração de lignina, a qual possui baixa degradabilidade.

Outra opção recomendada é a co-digestão dos resíduos vegetais, também chamados de biomassa, devido a potencializarão de produção de biogás. Entende-se por co-digestão a mistura de insumos de origem animal e vegetal. Verificou-se que não há diferença na digestão de lipídios vegetais e animais, os quais são as principais fontes de compostos voláteis.

Quanto a produção de biofertilizantes, KUROKI (2008) apresenta preliminarmente resultados positivos para a utilização dos efluentes como fertilizantes, fundamentado pelos baixos valores de DBO, DQO, coliformes totais e E.coli.

Há várias empresas que instalam, fazem a manutenção, capacitam usuários de biodigestores anaeróbios (Sansuy, Aqualimp,). Além disso, há pedidos de patente para novos modelos junto ao INPI. 
O tamanho do biodigestor é proporcional a quantidade de insumos que se pretende tratar e o tempo de retenção, dado pela formula: VB $=V C{ }^{*} T R H$ (OLIVER,2008), onde VB é o volume do biodigestor $\left(\mathrm{m}^{3}\right)$, VC é o Volume de carga diária (dejetos + água) $\left(\mathrm{m}^{3} /\right.$ dia) e o TRH é o tempo de retenção hidráulica (dias).

Conforme orienta Arruda (2002), o tempo de retenção ideal dura entorno de 35 a 45 dias com um percentual de água entre 60\% e 90\% do conteúdo total. A partir de 30 dias como tempo de retenção, são eliminados $90 \%$ dos organismos patogênicos. "A fermentação anaeróbica é hoje o tratamento mais eficiente e moderno para partes sólidas das fezes humanas em todas as estações de tratamento do mundo." (MASSOTI, 2002)

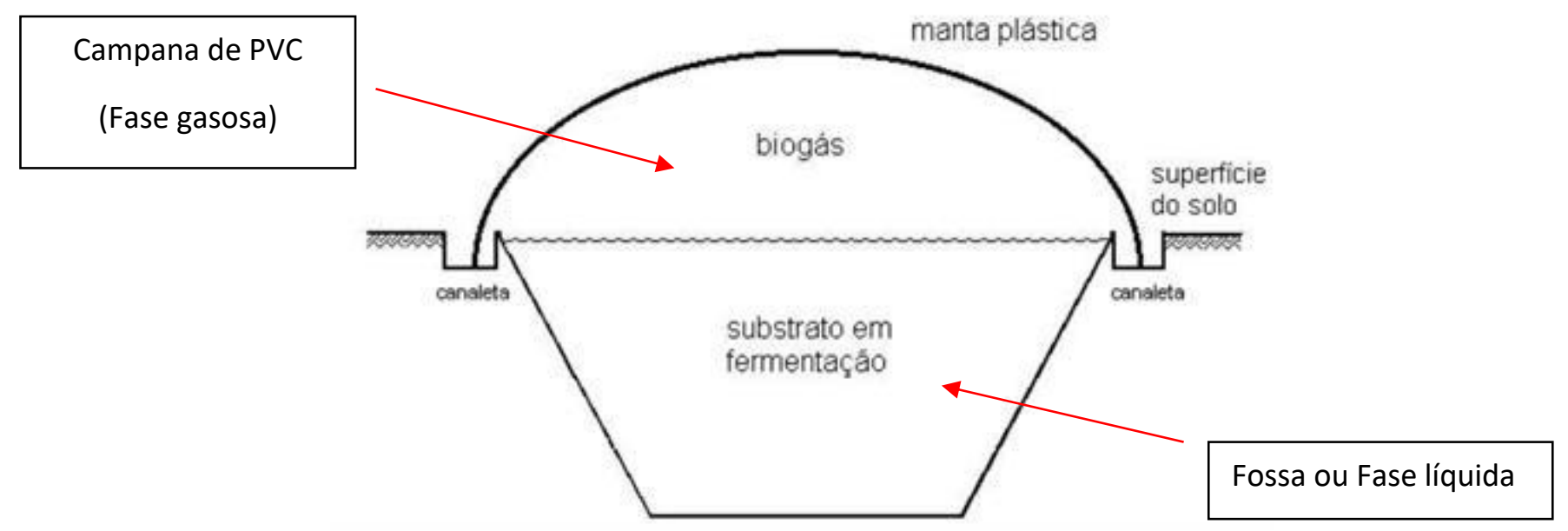

Figura 1 - Biodligestor Canadense. Fonte: Torres, 2012. Vista de perfil.

A partir da Figura 1 (TORRES, 2012) alterada conforme orientações de Ribeiro (2011), tem-se a proporção de 40\% máximo da fase gasosa sob a manta de PVC para manter as condições operacionais de produção de biogás. 
Oliver (2008) fornece as dimensões para a construção da base trapezoidal do biodigestor, conforme a tabela 1 .

\begin{tabular}{cccccc}
\hline $\begin{array}{c}\text { Volume } \\
\left(\mathbf{m}^{\mathbf{3}}\right)\end{array}$ & $\begin{array}{c}\text { Profundidade } \\
(\mathbf{m})\end{array}$ & $\begin{array}{c}\text { Comprimento } \\
\text { maior } \mathbf{C 1}(\mathbf{m})\end{array}$ & $\begin{array}{c}\text { Largura } \\
\text { maior } \\
\mathbf{L 1}(\mathbf{m})\end{array}$ & $\begin{array}{c}\text { Comprimento } \\
\text { menor C2 }(\mathbf{m})\end{array}$ & $\begin{array}{c}\text { Largura } \\
\text { menor } \\
\mathbf{L 2}(\mathbf{m})\end{array}$ \\
\hline $\mathbf{3}$ & 1 & 3,5 & 1,2 & 3 & 0,7 \\
$\mathbf{7}$ & 1 & 6 & 2 & 4,8 & 0,8 \\
$\mathbf{1 5}$ & 1,4 & 7 & 2,5 & 5,5 & 1 \\
$\mathbf{2 0}$ & 1,5 & 8 & 3 & 6 & 1 \\
$\mathbf{3 0}$ & 1,5 & 10 & 3,5 & 8 & 1,5 \\
\hline
\end{tabular}

Tabela 5 - Dimensões do biodigestor. Fonte: Oliver (2008).

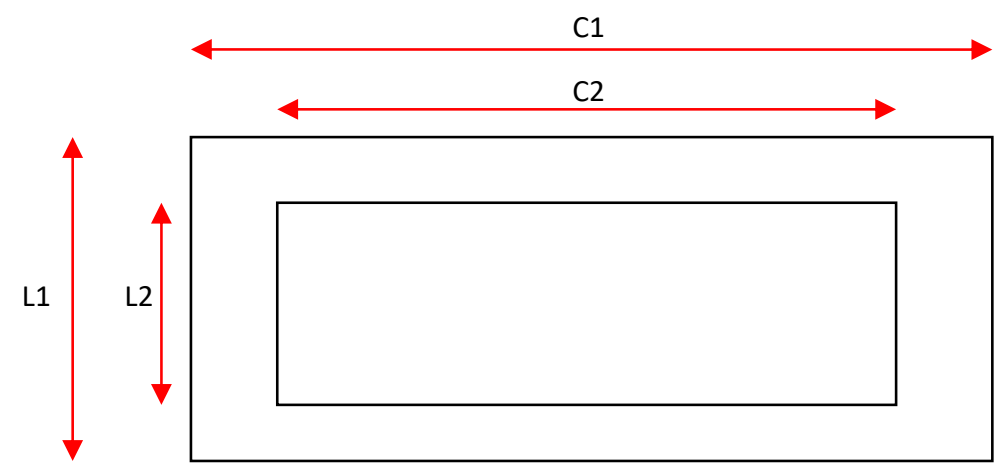

Figura 2 - Exemplo de modelo de Biodigestor. Vista superior.

E para a área da manta de PVC (tabela 6):

\begin{tabular}{cc}
\hline $\begin{array}{c}\text { Volume } \\
\left(\mathbf{m}^{\mathbf{3}}\right)\end{array}$ & $\begin{array}{c}\text { Área Total } \\
\left(\mathbf{m}^{\mathbf{2}}\right)\end{array}$ \\
\hline $\mathbf{3}$ & 43 \\
$\mathbf{7}$ & 68 \\
$\mathbf{1 5}$ & 99 \\
$\mathbf{2 0}$ & 127 \\
$\mathbf{3 0}$ & 161 \\
\hline
\end{tabular}




\subsubsection{Co-digestão}

Khalid et al. (2011) definem que ao se utilizar diferentes substratos em um biodigestor anaeróbio se está fazendo co-digestão. Desta forma, ao se utilizar o biodigestor para tratamento da fração orgânica dos resíduos sólidos municipais, se esta tratando de co-digestão necessariamente.

Anitha et al. (2015) defendem este conceito e o reforçam experimentalmente ao comprovarem que a mistura de mais de um insumo pode melhorar o rendimento e eficiência de funcionamento dos biodigestores anaeróbios.

Ebner et al. (2016) apresentam em seu experimento, resultados a partir de combinações de resíduos sólidos previamente separados e agrupado. Restos de alimentos segregados na fonte geradora (região dos lagos FINGER, Nova York). Seus resultados apontam para a alta biodegradabilidade de compostos ricos em gorduras de produção de metano.

Segundo Li, Park e Zhu (2011), Scano et al. (2014), Jin et al. (2015) o processo de co-digestão é indicado para grandes volumes de da fração orgânica de resíduos sólidos urbanos.

\subsubsection{Compostagem}

Segundo Bidone (2001), a compostagem é um processo aeróbio controlado que promove a estabilização da matéria orgânica. O material a ser estabilizado fica empilhado em pátio, em montes cônicos conhecido como leiras de compostagem. O processo de estabilização ocorre por ação dos microrganismos presentes, os quais transformam a matéria orgânica em uma substância preta chamada de húmus. 
A norma ABNT NBR 13.591/2010 define compostagem em seu item 2.22 como:

\footnotetext{
"Processo de decomposição biológica da fração orgânica biodegradável dos resíduos, efetuado por uma população diversificada de organismos, em condições controladas de aerobiose e demais parâmetros, desenvolvido em duas etapas distintas: uma de degradação ativa e outra de maturação."
}

Oviedo-Ocaña et al (2015) citam (Gustavsson et al., 2011) ao caracterizar a fração orgânica de resíduos sólidos urbanos como bioresíduos. Estes são formados praticamente de resíduos de frutas, vegetais e restos de comida. Ainda classifica a compostagem como o melhor método conhecido para a estabilização da matéria orgânica putrescível.

Oviedo-Ocaña et al (2015), Pan, Dam e Sen (2011), reforçam a necessidade dos resíduos serem segregados na fonte. E afirmam que a mistura de vários tipos de resíduos favorece a compostagem, reduzindo o tempo necessário para a decomposição dos materiais e a estabilização da matéria orgânica, atribuindo melhores características ao composto.

Pan, Dam e Sen (2011) experimentaram a inoculação de consorcio bacteriano (Bacilus e Pseudomonas) em um experimento piloto, o qual obteve a estabilização da matéria orgânica em 75 dias, com ph 7 e taxa de C:N 25:1.

Ince et al (2016) defende que a compostagem deveria ser implementada em larga escala com subsidio dos governos para tratar os resíduos sólidos orgânicos municipais.

Bidone e Povinelli (2010) dividem o este tratamento em 3 grupos: processo convencional (windrow); processo das leiras estáticas aeradas e os reatores aeróbios.

No processo convencional, os resíduos são amontoados nas chamadas pilhas de compostagem, as quais devem ser revolvidas periodicamente e ume- 
decidas de modo manual (pás), mecanizados (escavadeiras ou compostadores figura 3).

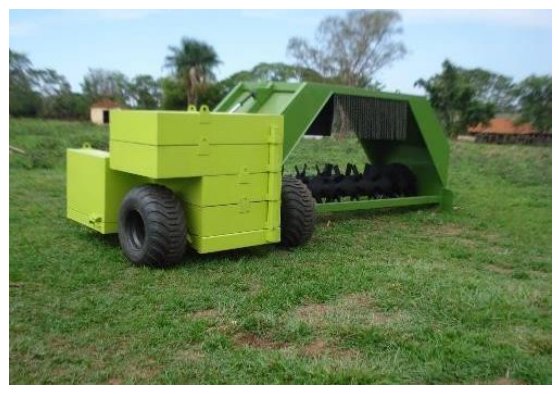

Figura 3 - compostador da empresa SoloStocks (http://www.solostocks.com.br)

No processo de Leiras Estáticas Aeradas (LEA), segundo os autores, não há o revolvimento cuja necessidade seria deixar o ar e o oxigênio permear toda a massa de resíduos. Como ocorre o insuflamento de ar através da base da pilha de compostagem, o processo ocorre normalmente. Há algumas variações onde são incorporadas culturas bacterianas para este fim.

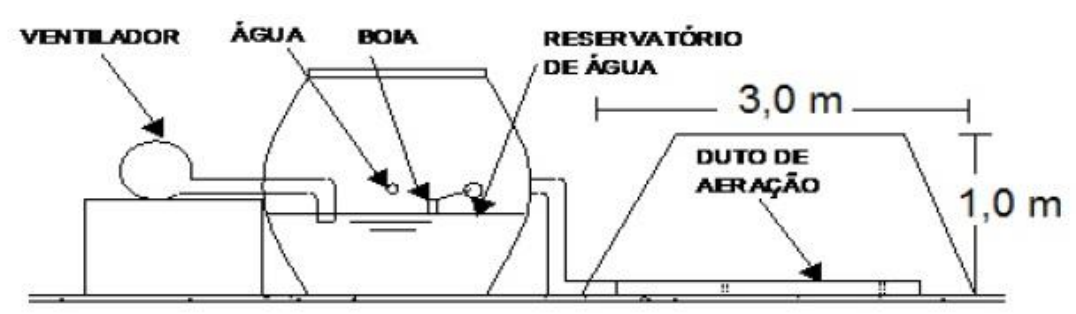

Figura 4 - Esquema de compostagem por LEA. Barros (2012)

Já nos chamados reatores ou usinas de compostagem, os resíduos são colocados dentro de cilindros rotativos.

De modo similar aos biodigestores, na compostagem também ocorrem em 4 estágios ou fases. Contudo, aqui há um consorcio microbiano entre bactérias e fungos ao executarem a fermentação dos compostos orgânicos. Esta fase inicial é caracterizada pelo aumento de temperatura, chegando a faixa entre $55^{\circ}$ e $60^{\circ} \mathrm{C}$, num período de $12 \mathrm{~h}$ a $24 \mathrm{~h}$. Caso não ocorra a redução da temperatura, o processo é interrompido ao atingir cerca de $70^{\circ}$. Desta forma, a 
umidade exerce dois papeis fundamentais, manter a atividade microbiana e reduzir a temperatura.

Nestas condições, a decomposição completa dos resíduos orgânicos ocorre num período de cerca de 60 a 90 dias no método tradicional ou 30 dias nas LEA's. Com a temperatura mantida nesta faixa ideal, ocorre a eliminação dos patógenos. Esta é a fase 2. Bidone e Povinelli (2010).

Após este processo, em torno de 4 dias, a temperatura da leira se iguala a do ambiente, configurando a fase 3. Por fim, com a geração de ácidos húmicos e o escurecimento do composto, após um período de 30 a 60 dias, ocorre a estabilização completa da massa compostada (fase 4) (Calijuri e Cunha).

A titulo de exemplo, tem-se a província de Quebec (Canadá) cuja população em 2012 era de 8.085.900 de pessoas, as quais geraram 5.776 .000 de toneladas para este ano. Sendo $27 \%$ deste total (1.559.520 ton) correspondente aos resíduos sólidos residenciais e $20 \%$ correspondentes a resíduos sólidos industriais, comerciais e institucionais (1.155.200 ton). Segundo HÉNAULTETHIER et al.(2016), foram reciclados 25\% (389.880 ton) dos resíduos sólidos orgânicos residenciais e 29\% (335.008 ton) dos resíduos sólidos orgânicos industriais, comerciais e institucionais, através da atuação de usinas de compostagem. O autor afirma que é o objetivo do Governo canadense a completa supressão do encaminhamento de material putrescível para aterros sanitários até 2020 utilizando composteiras em pequena escala, localmente diretamente na geração.

Corroborando com esta opinião, Siqueira e Assad (2016) acompanharam as formas de compostagem no estado de São Paulo (Brasil) e constataram que compostagem de modo descentralizado apresentam custo muito baixo e são mais eficientes do que composteiras centralizadas. 
Siqueira e Assad (2016), Bidone e Povinelli (2010), HÉNAULT-ETHIER et al.(2016), Amaral et al (2015) apontam a compostagem como uma estratégia a ser adotada de modo atomizado a fim de potencializar seus efeitos.

\subsubsection{Vermicompostagem}

PATHMA; SAKTHIVEL, (2012) definem vermicompostagem como um processo bioxidativo não termofílico que ocorre por ação de minhocas (vermes) em associação com microrganismos presentes no solo. Após a estabilização da matéria putrescível, o material resultante é um fertilizante chamado vermicomposto, que de modo heterogêneo, definido como turfa, poroso, com boa retenção de umidade e rico em nutrientes necessários para o solo em que se pretende cultivar.

De modo semelhante HÉNAULT-ETHIER et al.(2016) definem "vermicompostagem como um processo de bio-oxidação mediado por minhocas epigênicas, que agem sinergicamente com micróbios para estabilizar a matéria orgânica" (tradução própria).

Este tratamento é baseado na associação de minhocas às leiras de compostagem. Segundo Bidone e Povinelli (2010), não pode haver muita umidade, o que culminaria no afogamento das minhocas; nem pouca umidade. A faixa ideal de umidade fica entre $60 \%$ e $80 \%$, com profundidade máxima de $30 \mathrm{~cm}$, salvo nos casos das LEA's, devido a aeração forçada.

A associação das minhocas, ao digerirem partículas maiores presentes no solo, facilita a atividade da microbiota do solo, a qual ira realizar a estabilização matéria orgânica. Bactérias presentes no solo competem entre si e com fungos. A associação com as minhocas beneficia as bactérias não patogênicas. Lavelle and Martin (1992) descrevem o mutualismo entre as minhocas e bactérias, quando as minhocas defecam e liberam juntamente com as fezes as bactérias e muco. Tal condição acelera a atividade microbiana (isso para minhocas de regiões tropicais). 
A alimentação das espécies estudadas por Edwards e Fletcher, 1988 (apud PATHMA e SAKTHIVEL, 2012), como por exemplo Drawida calebi, Lumbricus terrestris e Eisenia foetida, apresentou em sua composição algumas leveduras, poucos protozoários, e em destaque alguns fungos, principalmente para as espécies Fusarium oxysporum, responsável pela praga do amarelamento em culturas de feijão (ITO, 2004); Alternaria solani, responsável pela praga da pinta-preta em culturas de tomate (ARAUJO, 2004) e batatas (SIMON E LAMBERT, 2009). Também foram relatadas a ingestão e destruição completa de microfungos, que segundo RODRIGUES (2009) são compostos por leveduras e fungos filamentosos.

Ainda, PATHMA e SAKTHIVEL (2012) relatam que as minhocas também tiveram papel relevante no controle populacional das bactérias Bacillus cereus, as quais são responsáveis por graves infecções gastrintestinais, deterioração de alimentos e formação de esporos (Robinson e Phill, 1987 APUD VIDALMARTINS,2005). Os autores também descrevem a eliminação das populações de Escherichia coli e Serratia marcessens.

Cabe descrever que as minhocas podem ser classificada de acordo com a região onde se localiza. Pathma e Sakthivel (2012) descrevem as minhocas como epigênicas, que são minhocas fitófagas e habitam a superfície do solo e apresentam alta capacidade de conversão de matéria orgânica em vermicomposto; as endogênicas que são geófagas, habitam abaixo da superfície e se deslocam predominantemente de forma horizontal. São importantes para mudar a estrutura do solo; e as anécicas. Estas são fitófagas, de hábitos noturnos, estão associadas com a entrada de ar em camadas mais profundas, pois transitam entre a superfície e o interior do substrato de modo vertical.

A introdução das minhocas ao solo ocorre após a fase 3 da compostagem, a fim de se manter as temperaturas entre $12^{\circ} \mathrm{C}$ e $25^{\circ} \mathrm{C}$, e desta forma evitando a morte das minhocas. Bidone e Povinelli (2010), recomendam a introdução de 1500 a 2500 minhocas por $\mathrm{m}^{2}$ para a estabilização completa num período entre 45 e 60 dias. 


\subsubsection{Tratamento térmico}

Conforme a definição apresentada por Rodrigues, Marcilio e Secchi (2008), o tratamento térmico é definido como o uso do calor para a quebra das ligações químicas dos componentes perigosos, convertendo-os para formas menos tóxicas. Ainda apresenta como as formas principais desta tecnologia a combustão (incineração), pirólise e gaseificação.

Já Barros (2013), Calijuri e Cunha (2013) apresentam como tecnologias de tratamento térmico a incineração, pirólise, plasma, micro-ondas e autoclave. Muitas destas tecnologias são utilizadas principalmente no tratamento de resíduos sólidos de saúde, contudo, podem ser aplicados para resíduos sólidos urbanos. Principalmente quando aplicar a recuperação energética através do enfoque Waste to Energy (WTE), que segundo Barros (2013) e Gug et al (2015), Chen et al (2015) é uma tendência mundial.

A Resolução CONAMA 316 de 2002 que define em seu art. 2, item III "Tratamento Térmico: para os fins desta regulamentação é todo e qualquer processo cuja operação seja realizada acima da temperatura mínima de oitocentos graus Celsius". Além de definir parâmetros de operação, teste, avaliação, e descontinuidade das usinas de tratamento térmico.

\subsection{Incineração}

A incineração é a combustão dos resíduos sólidos urbanos com a presença de oxigênio, conhecido como ar de combustão em conjunto com um combustível auxiliar como descreve Barros (2013). Calijuri e Cunha (Cempre, 2000 apud 2013), descrevem o processo como a queima de qualquer material orgânico com temperaturas acima de $800^{\circ} \mathrm{C}$ com injeção de ar para a conversão completa dos resíduos em $\mathrm{CO}_{2}$ e água. 
Segundo Juca et al (2013), após a incineração são gerados 3 subprodutos: sólidos (cinzas e escórias), gases e líquidos. Após a estabilização da parte sólida, devem ser destinadas aos aterros sanitários. A parte liquida requer um tratamento prévio para a sua estabilização com consequente tratamento em estações especificas e a porção gasosa, merece atenção especial, pois é necessária a remoção de compostos como óxido de enxofre $\mathrm{SO}_{2}$, óxido de Nitrogênio $\left(\mathrm{NO}_{2}\right)$, oxigênio residual $\left(\mathrm{O}_{2}\right)$ e material particulado.

Calijuri e Cunha (2013), Barros (2013), FEAM (2010), (Alencar Junior e Gabai (2001) alertam para a geração de compostos secundários conhecidos como Dioxinas e Furanos que devem ser captados por filtros. Como no Brasil a incineração para tratamento de resíduos é aplicada apenas para resíduos de serviço de saúde, é regulada pela ABNT NBR 11175:1990, a qual estabelece que a eliminação destes compostos gasoso deve ser acima de 99,9\%.

Muito aplicada no Japão, Europa e EUA, é recomendada para volumes em torno de 160 mil toneladas de resíduos por ano ou 240 toneladas/dia, mantendo o fluxo de 8 a 10 t/h e no mínimo por 8mil horas/ano (GANDOLLA, 2012 apud JUCA ET Al, 2013). Esta tecnologia é capaz de reduzir em cerca de 90 do volume dos resíduos e em cerca de $70 \%$ da massa total (CALIJURI E CUNHA, 2013). Gug et al, 2015 e MANNARINO et al (2016), recomendam a incineração como tratamento térmico para grandes volumes de RSU inorgânicos.

Segundo FEAM (2010) a incineração ou combustão pode ser agrupada em 5 tipos de rotas tecnológicas: (i) combustão em grelha; (ii) combustão em leito fluidizado; (iii) Combustível Derivado de Resíduos; (iv) Gaseificação e Pirólise e (v) Arco de Plasma. Calijuri e Cunha (2013) e Barros (2013) acrescentam micro-ondas e autoclave.

Morgado e Teixeira (2006) descrevem o tratamento térmico por incineração e as medidas para a redução e controle das emissões atmosféricas de dioxinas, furanos e particulados em dois estágios. No primeiro, uma câmara recebe os RSU de modo indissociado, e os incinera a temperaturas que se situam entre $500^{\circ} \mathrm{C}$ e $900^{\circ} \mathrm{C}$ em ambiente inferior ao necessário de oxigênio para 
a combustão completa dos Residuos (sub-estequimétrico), minimizanbdo a geração de oxido nitroso e a volatilização de compostos metálicos. No segundo estagio, a maioria dos materiais orgânicos se volatilizou. Neste estágio, os RSU são queimados por 30 minutos.

Numa segunda câmara, com temperaturas de até $1250^{\circ} \mathrm{C}$, o material particulado e os volatilizados são queimados por cerca de 3 segundos neste ambiente, agora altamente oxidante convertendo a maior parte dos compostos em $\mathrm{CO}_{2}$ e $\mathrm{H}_{2} \mathrm{O}$. Neste segundo estágio, a tendência de permanência de composto como dioxinas e Furanos praticamente zero (Morgado e Teixeira, 2006).

Após este processo, os gases são tratados, de modo a remover ácidos presentes (método scrubber - exposição dos gases a oxido de cálcio), precipitador eletrostático para captação de particulados, filtros, leito fluidizado de carvão ativo para a retenção de oxido nitroso. (Buekens e Huang, 1998; Morgado e Teixeira 2006).

\subsection{Incineração em grelha}

A forma tradicional de queima de resíduos é chamada de tratamento térmico em massa, onde são retirados os itens pesados, com a consequente mistura dos resíduos e sua posterior incineração (em presença de oxigênio). Atualmente as usinas de incineração mais modernas da Europa são preparadas para recuperar (reciclar) a energia contida nestes resíduos para gerar vapor, eletricidade e agua quente (FEAM, 2010).

O processo é realizado com a passagem dos resíduos por uma grelha, dentro de uma câmara fechada, onde o ambiente é aquecido, o que promove a secagem dos resíduos, liberação de material volátil, queima dos compostos orgânicos. Cerca de $60 \%$ do ar de combustão é injetado por baixo da grelha, sendo este pré-aquecido, com a função de resfriar, secar e auxiliar a combustão do material. Já os $40 \%$ restantes são dispersos sobre a massa de resíduos, 
em alta velocidade a fim de promover a mistura de gases oriundos da combustão por turbilhonamento (FEAM, 2010).

Ainda conforme Feam (2010), a temperatura recomendada é de $1200^{\circ} \mathrm{C}$, para que a maioria dos compostos orgânicos sejam transformados em $\mathrm{CO}_{2} \mathrm{e}$ água. Não raro, também se constatam a presença de outros compostos, principalmente gases corrosivos (ácido clorídrico, outros compostos a base de cloro, etc). A temperatura desses gases não deve ultrapassar $420^{\circ} \mathrm{C}$ e a tubulação próxima à grelha deve ser revestida com material refratário. Posteriormente são coletados a uma temperatura de $250^{\circ} \mathrm{C}$ e levados para tratamento, para a remoção dos poluentes. $O$ resíduo formado por cinzas e material orgânico não incinerado, que são resfriados em água.

Neste processo, pode existir a queima indiscriminada dos resíduos (Mass Burn ou Queima em Massa) (Figura 1), onde não é realizada a remoção de plásticos, madeira e papeis. Desta forma, com a incineração, a energia contida nestes materiais é liberada e aproveitada. Para 100 mil toneladas/ano são recuperados $7 \mathrm{MWh}$ de energia. Há ainda a possibilidade de separação previa dos recicláveis antes de promover a incineração (Queima de Não Recicláveis). Com isso, o poder calorífico do processo é bem reduzido, diminuindo assim a capacidade de utilização da energia residual (FEAM, 2010).

Juca et al (2013) reforçam a informação que este processo é recomendado para o tratamento de grandes volumes de resíduos sólidos. Além de ter como vantagens a redução do material a ser disposto em aterros, menor necessidade de espaço para a instalação da usina, redução e controle das emissões atmosféricas e odores.

Como desvantagens, são apontados o elevado custo de instalação, operação e manutenção, além da inviabilidade de incineração de resíduos com alto teor de umidade, de pequeno poder calorífico e resíduos sólidos contendo clorados. 


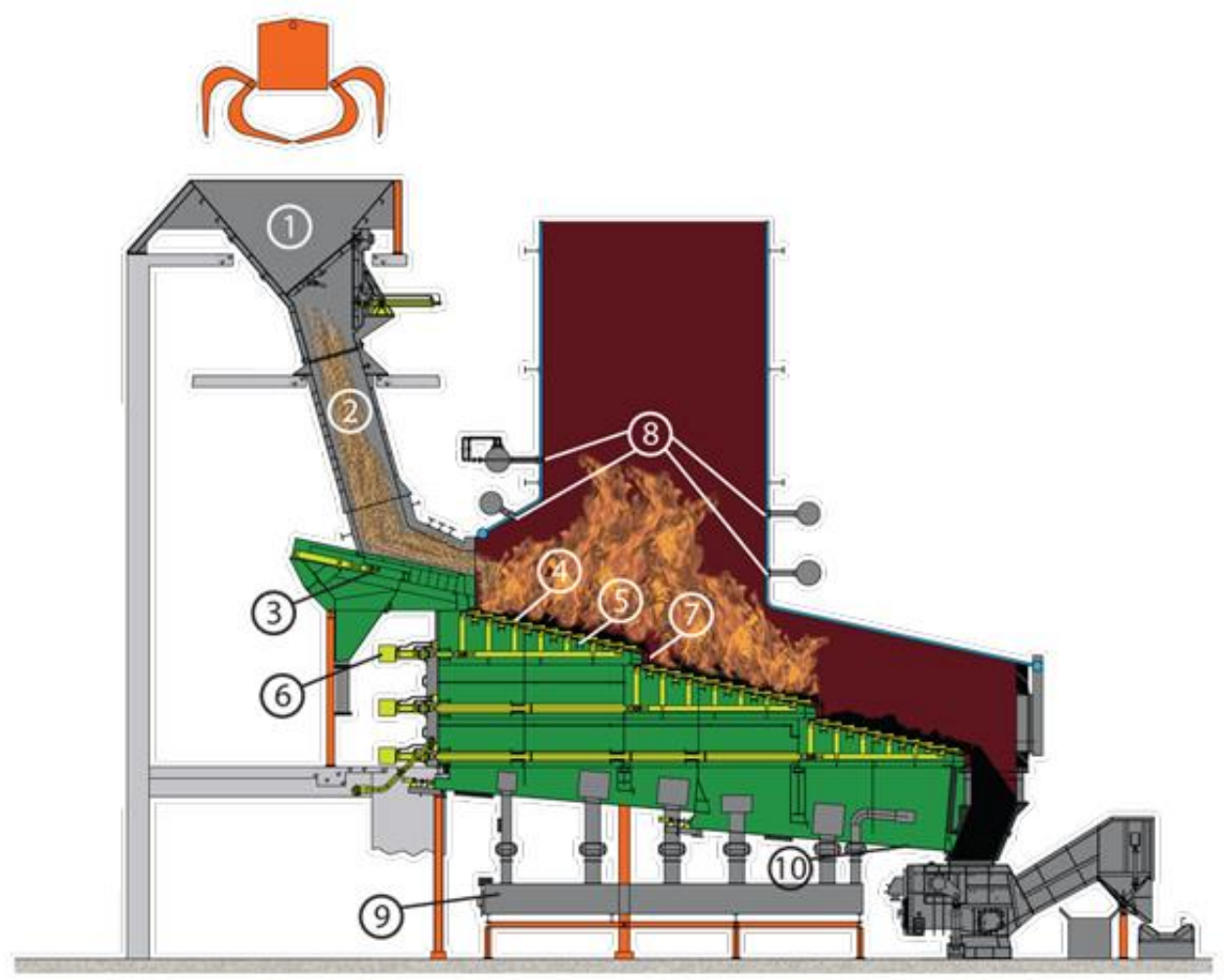

Figura 5 - Adaptado de Detroit Stoker Company, 2012 - QUEIMA EM MASSA com recuperação de energia

1. Tremonha - O lixo é transportado do depósito para a tremonha, que se estende por toda a largura da fornalha. 2. Garganta - faz parte integrante do sistema carregador de lixo. É protegida do calor da fornalha e tem sua durabilidade assegurada por revestimento refratário ou resfriamento por água. 3. Empurrador - de acionamento hidráulico, empurra o lixo de maneira uniforme para dentro da fornalha e sobre a primeira seção da grelha. Vários empurradores são usados nas unidades de maior porte, para que a alimentação seja contínua. 4. Elementos da Grelha - fundidas de material especial com alto teor de níquel/cromo, para maior durabilidade. São montados em filas de elementos móveis e fixos. Os elementos móveis alternam-se continuamente sobre os elementos fixos, empurrando o lixo através da fornalha. 5. Rolamentos de Rolos - a estrutura da grelha movimenta-se sobre roletes, equipados com rolamentos cônicos de rolos, para reduzir atrito e desgaste. Os roletes e a pista-guia são protegidos das cinzas. 6. Cilindros Hidráulicos e Válvulas de Regulagem - previstos para cada seção longitudinal da grelha e empurrador de lixo, comandados individualmente por um controle eletrônico tipo solid state. Os cilindros são ligados diretamente à estrutura móvel da grelha. 7. Escape Vertical revestido com tubeira para entrada de ar fabricada de material de alto teor de níquel/cromo. $O$ escape vertical é disposto entre as seções da grelha, permitindo descompactar e guiar grandes blocos de lixo. 8. Jatos de Ar Secundário - estrategicamente instalados para criar turbulência, misturar os gases voláteis e assegurar que a combustão seja completa. 9. Ar de Combustão insuflado embaixo de cada seção da grelha. A distribuição do ar no interior da fornalha é feita por meio de orifícios eqüidistantes, próximos entre si, juntos à extremidade dos elementos da grelha. Resfriam a grelha de maneira uniforme para maior durabilidade. Para otimizar o fluxo 
de ar, cada módulo, ou seção da grelha, é dotado de suprimento de ar independente. 10. Removedor Automático de Detritos - transporta para a descarga da unidade e para dentro do transportador principal, ou tremonha, os detritos que ficam embaixo do empurrador de lixo e de cada seção da grelha. Esse sistema funciona automaticamente.

\subsection{Incineração em leito fluidizado}

A combustão em leito fluidizado ocorre em numa câmara onde os resíduos sólidos são previamente triturados e incinerados em suspensão, promovidas por correntes ascendentes (primário) de ar que revolve o fundo permanentemente, o qual é composto por material inerte (areia ou cinzas) que se comporta de maneira similar a um fluido em ebulição, originando o nome Leito Fluidizado (LF). Esta corrente de ar é gerada por um distribuidor dimensionado para este processo, e que fica situado abaixo da caldeira (FEAM, 2010).

Há dois conceitos dessa tecnologia: Incineração em Leito Circulante e Incineração em Leito Borbulhante (Figura 2). Em ambos os conceitos, devese manter os resíduos triturados com tamanho uniforme, assim como a granulometria do material inerte, controlada (FEAM, 2010).

$O$ processo se inicia com o aquecimento dos queimadores auxiliares alimentados a óleo. Quando a temperatura chega a $400^{\circ} \mathrm{C}$ os resíduos sólidos são lançados acima do leito ou dentro dele, sendo agitados pelas correntes de ar. Tal processo permite que a areia e os resíduos triturados troquem calor rapidamente, causando a combustão. Quando a temperatura atinge os $600^{\circ} \mathrm{C}$, os queimadores auxiliares são desligados e o processo se mantem com a combustão dos resíduos. As cinzas mais pesadas são removidas pelo fundo através da ação de extratores mecanizados. As cinzas mais leves (cinzas volantes) são carreadas pelas correntes de ar e coletadas pelos sistemas de limpeza de gases (FEAM, 2010).

Alguns compostos orgânicos sólidos ou gasosos que não tenham sido consumidos no processo, são queimados na região conhecida como free- 
board, situada na região acima do leito e posteriormente conduzidos à recuperação energética e a limpeza dos de gases (FEAM, 2010).

Esta tecnologia apresenta como vantagens a possibilidade de neutralizar os gases ao se acrescentar cal ou calcário durante o processo de queima. Quando comparada a queima em grelha, custa menos devido a menor necessidade de filtros e controladores de gases pelo fato de muitos gases serem neutralizados durante o processo (FEAM, 2010).

Pelo fato de possuírem a necessidade de um pré-processamento dos resíduos para a redução do tamanho, aumenta o custo de sua aplicação. Os resíduos sólidos triturados e pré-tratados para serem utilizados neste processo, de modo geral, passam a receber o nome de Combustível Derivado de Resíduo (CDR). Somado a isto, esta tecnologia é adequada a pequenos volumes de resíduos gerados, sendo indicada para comunidades de pequeno porte. Estas características promovem a separação dos resíduos de modo prévio, favorecendo a recuperação de recicláveis. Outra desvantagem relevante é o alto custo com capacitação dos operadores da usina de incineração, além da necessidade de equipamentos mais sofisticados, aumentando o custo operacional (FEAM, 2010). 


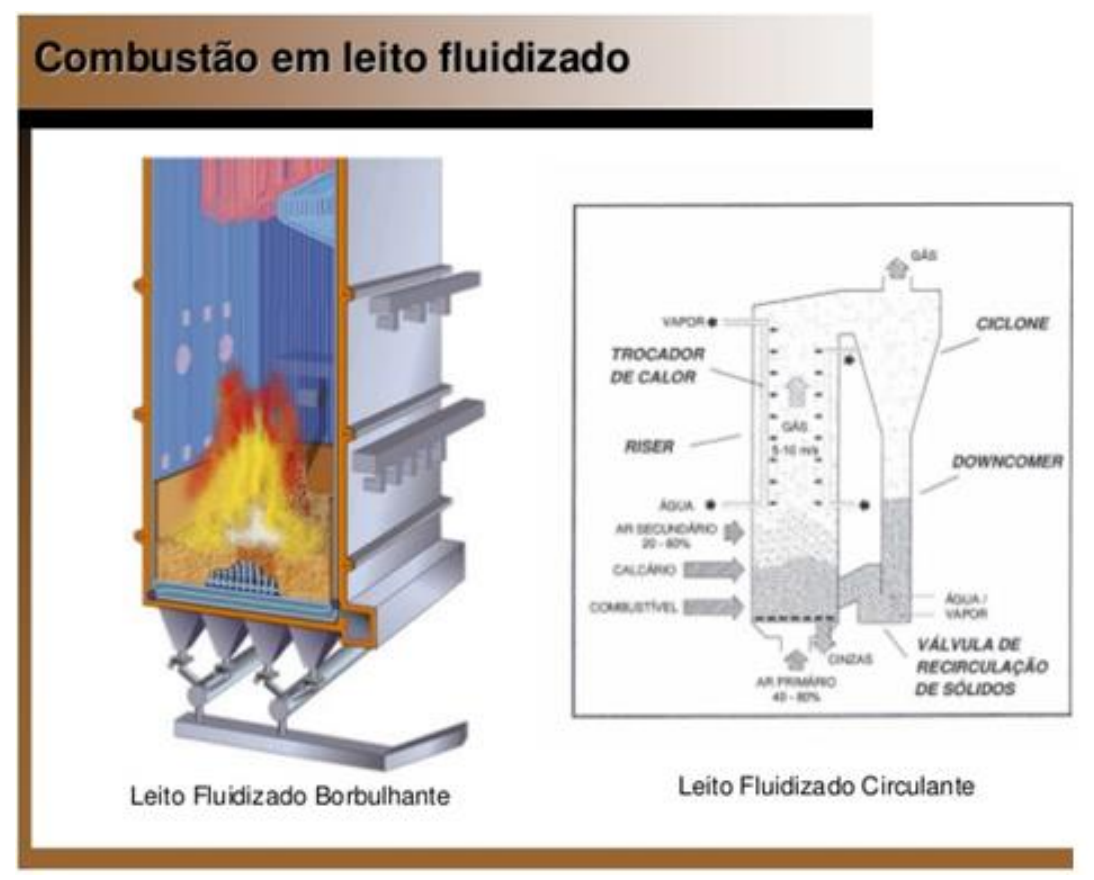

Figura 6 - Adaptado de OLIVEIRA, 2015.

\subsection{Combustível Derivado de Resíduo}

O combustível Derivado de Resíduo (CDR) ou em inglês RDF - "Refuse Derived Fuel", segundo Juca et al (2013), é uma forma de tratamento de Resíduos Sólidos Urbanos que requer um beneficiamento dos resíduos, passando pela separação de metais ferrosos e não-ferrosos (para reciclagem), secagem e trituração posterior deste resíduos. Após este processo, passam a disponibilizar alto poder calorífico (18 megajaules por kg).

Rada e Ragazzi (2015) reportam que na União europeia, a primeira referencia ao termo CDR apareceu na norma UNI 9903:1-14, "O RDF é combustível derivado de resíduos sólidos urbanos através de tratamentos destinados à eliminação de substâncias perigosas para a combustão e para garantir um valor de aquecimento adequado (Lower Heating Value - LHV) e para cumprir as normas técnicas para sua caracterização". 
Ainda segundo o autor acima citado, as etapas obrigatórias de processamento dos resíduos são: (a) Separação dos resíduos; (b) trituração; (c) secagem. Há algumas indústrias que exigem maior processamento, e desta forma, incluem as seguintes etapas posteriores: (d) refino (granulometrias menores) e (e) peletização (para transporte e estocagem).

Gallardo et al (2014) definem Combustível Derivado de Resíduos (ou refugo) como o resíduo que sofreu tratamento ou processamento a fim de ser homogeneizado, ter retirada sua umidade e fragmentado (por vezes transformado em pellets) e separado de elementos não combustíveis.

A norma ATSM (American Society for Testing and Materials) E856-83 (2006) classifica em 7 tipos os CDR's:

- RDF-1: Resíduos utilizados na forma descartada;

- RDF-2: Resíduos transformados em partículas grossas com ou sem metais ferrosos separados, de modo que $95 \%$ em peso passam através de peneira, também conhecidos como RDF grosseiro;

- RDF-3: Resíduos que após separados vidro, metal e materiais inorgânicos, são triturados de tal modo que $95 \%$ em peso passam através de peneira, nomeadamente, também conhecido como Fluff RDF;

- RDF-4: Resíduos combustíveis moídos (transformados em pó), também conhecidos como Powder RDF;

- RDF-5: Resíduos combustíveis densificados (comprimidos) sob a forma de peletes, cubos ou briquetes, também conhecidos como Densified RDF;

- RDF-6: Resíduos combustíveis transformados em combustíveis líquidos, também conhecidos como RDF em suspensão;

- RDF-7: Resíduos combustíveis transformados em combustíveis gasosos, também conhecidos como gás de síntese de RDF. 
Neste tipo de tratamento, há a geração de rejeitos que, dependendo da exigência do processo, pode variar de $20 \%$ a $80 \%$. Estes devem ser encaminhados para disposição final. Juca et al (2013) informam que este processo não é recente e traz como principal função a sua utilização posterior como combustível. Feam (2010) difere este processo de tratamento do processo anterior (queima em grelha) pelo processamento em dois grupos de etapas independentes $(a+b+c$ e $d+e)$.

Como características intrínsecas a esta tecnologia, Juca et al (2013) apontam o gasto de energia com a trituração, bem como o consumo de energia propriamente dita para a condução das etapas do processamento são os gargalos desta forma de tratamento. Pode-se considerar este tratamento autossustentável, desde que o saldo de energia produzida seja superior ao gasto (dependerá da qualidade dos resíduos sólidos) e que não gere rejeitos contaminados. A presença de metais tóxicos e contaminantes pode inviabilizar este tipo de tratamento (FEAM, 2010).

Pinto (2009) apresenta ainda o termo Combustível Sólido Recuperado (CSR) como um beneficiamento dos CDR's que os enquadrem nas normas e especificações de qualidade. Diferentemente dos anteriores que são necessariamente classificados como resíduos.

Rada e Ragazzi (2015) já fazem referencia aos CSR como combustíveis processados a partir de resíduos não perigosos e que após transformação, homogeneização e valorização de modo a garantir qualidade e ser comercializados e utilizados em instalações de incineração, de acordo com os padrões estabelecidos pela norma CEN / TS 15.359:2011 (e complementada pela CEN/TC 343 - "Solid Recovered Fuels" - destaque próprio).

Como principais vantagens deste tipo de tratamento, Juca et al (2013) mencionam a interrupção da decomposição da matéria orgânica presente nos resíduos a fim de armazená-los em silos para uso futuro; a possibilidade de transportar os CDR's para utilização em outros locais em que haja a demanda; transformação de RSU em fontes de energia, e desta forma agregando-Ihes 
valor econômico; possibilidade de instalação próximo aos centros geradores, reduzindo o gasto com a logística; redução das emissões e redução do uso de aterros. Como principais desvantagens, o autor destaca o alto consumo de energia e a possibilidade de contaminação dos CDR's por metais.

\subsection{Gaseificação}

A gaseificação pode ser compreendida como um processo de oxidação controlado e parcial, o qual pode ser continuo ou em batelada que utiliza ar, oxigênio ou vapor aquecido. Como produto deste processo, há o SYNGAS, formado principalmente por monóxido de carbono, hidrogênio, e em quantidades menores de gás carbônico, hidrocarbonetos leves, metano, nitrogênio e vapor de água (FEAM, 2013).

Andrade (2007) define gaseificação como o processo de geração de gases combustíveis a partir do aquecimento da matéria orgânica (também denominada biomassa) - Duric et al (2014) também incluem a parte orgânica os resíduos sólidos como biomassa - em ambiente pobre em oxigênio. Estes gases são principalmente o $\mathrm{CO}_{2}, \mathrm{CO}, \mathrm{H}_{2}, \mathrm{CH}_{4}, \mathrm{H}_{2} \mathrm{O}, \mathrm{N}_{2}$, hidrocarbonetos simples, alcatrão e particulados.

De acordo com Feam (2013), o SYNGAS pode ter aplicações práticas para a produção de energia mecânica, elétrica, calor ou na produção de combustíveis sintéticos. A composição do SYNGAS está diretamente ligada ao tipo de forno de gaseificação, a forma de fornecimento de energia do processo, uso de vapor associado ao comburente (ar ou oxigênio), tempo de detenção, sistema de retirada de gases e o tipo de insumo do processo. Além disso, há a produção de carvão (sólidos) e líquido pirolenhoso.

Fornos de gaseificação projetados objetivando a produção comercial de SYNGAS, pela necessidade de purificá-lo possuem custo elevado, além de produzir baixos níveis de alcatrão e liquido pirolenhoso. São fornos revestidos 
com material refratário, que operam em temperaturas que funcionam entorno de $850^{\circ} \mathrm{C}$ e que podem funcionar em pressão atmosférica ou pressurizado (BRAND, 2010 apud FEAM, 2013).

Há dois tipos de gaseificadores de acordo com o tipo de leito utilizado. São eles:

- Leito fixo: é a tecnologia mais difundida e pode ser subdividida de acordo com o fluxo dos resíduos em relação à corrente de ar aquecido. Podem ser de corrente paralela (ou concorrente) (downdraft) ou de contracorrente (updraft) (CENBIO, 2002 e FEAM, 2013).

Já Andrade (2007) classifica os gaseificadores de acordo com a pressão de trabalho (atmosférico ou pressurizado); de acordo com o tipo de leito (fixo ou fluidizado), para o caso do tipo fixo, ainda como contracorrente ("up draft"), concorrente ("downdraft") e fluxo cruzado; já os de leito fluidizado, como leito borbulhante e leito circulante.

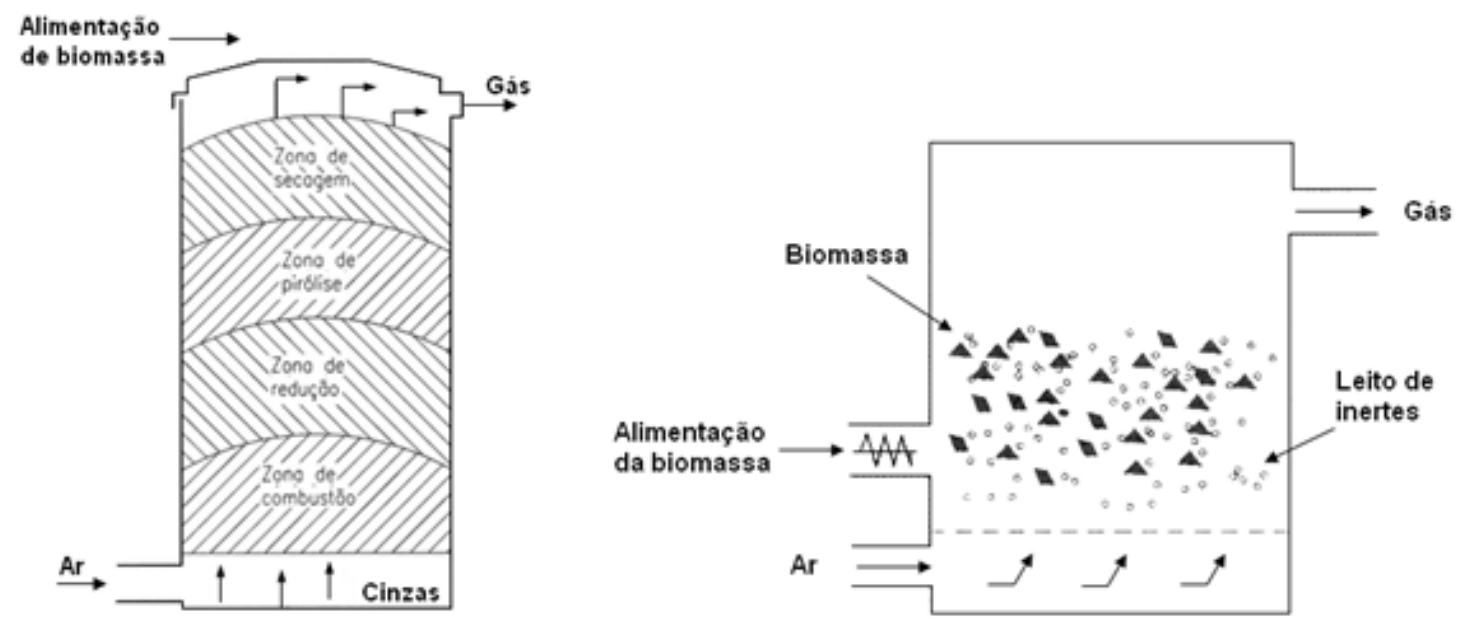

Figura 7 - Desenhos esquemáticos dos gaseificadores contracorrente e de leito fluidizado. Fonte: (Cortez, Lora e Gómez,2009 apud FEAM, 2013).

O uso da gaseificação é preferível à incineração pelo fato de alcançar menor emissão de poluentes, possuir maior controle sobre a queima, além de ter aplicações domesticas (Andrade, 2007; Rollinson e Karmaker, 2015; Arena, 
2012; Chen et al, 2015). Contudo, exige maiores cuidados e aporte tecnológico, além de apresentar menor eficiência de conversão energética. (ANDRADE, 2007)

Rollinson e Karmaker,(2015) recomendam o uso de gaseificadores de leito fixo concorrente, devido a facilidade do uso em relação aos demais para resíduos sólidos em pequena escala. Contudo, Arena (2012) conclui que apesar da gaseificação ser uma tecnologia eficiente, ainda traz alguns problemas de ordem técnica que impactam negativamente como solução para tratamento de resíduos sólidos municipais, devido a natureza heterogênea de seus componentes.

Durante a segunda guerra mundial, o Brasil possuía uma frota de cerca de 20mil carros movidos a gaseificadores de leito fixo portáteis (figura $x \times x 3$ ), que utilizavam nacos de madeira, coque, turfa e antracito como fonte combustível. (Andrade, 2007)

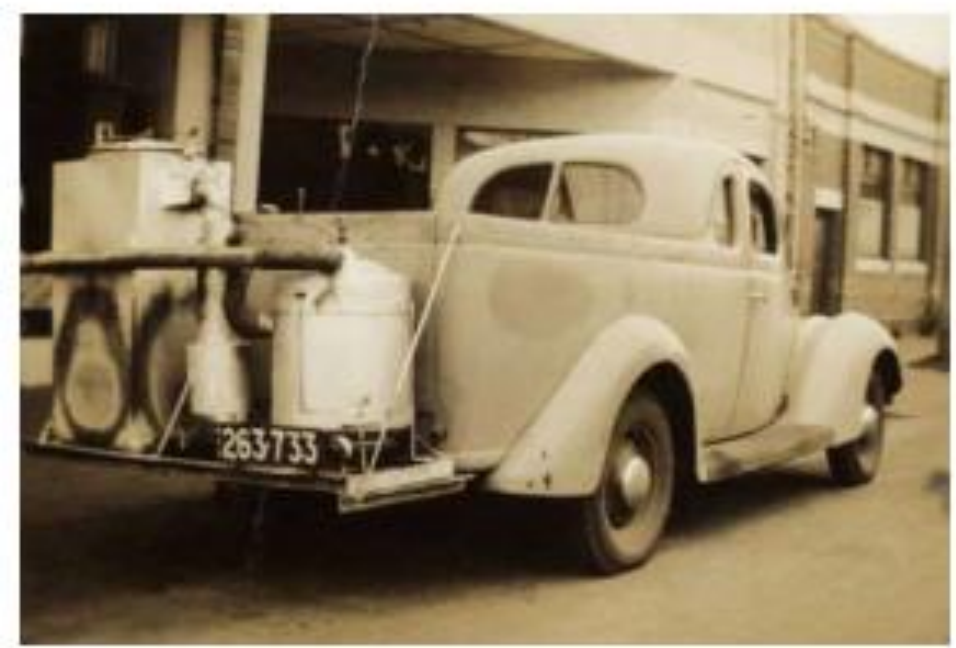

Figura 8 - Gaseificador Imbert e veículo acionado por gás de biomassa. (ANDRADE, 2007). 


\subsection{Tipos de gaseificadores}

Conforme já enumerado por Andrade (2007), existem os gaseificadores de leito fixo (contracorrente, concorrente e de fluxo cruzado; e os de leito fluidizado (circulante e borbulhante).

\subsection{Gaseificador contracorrente ("up draft")}
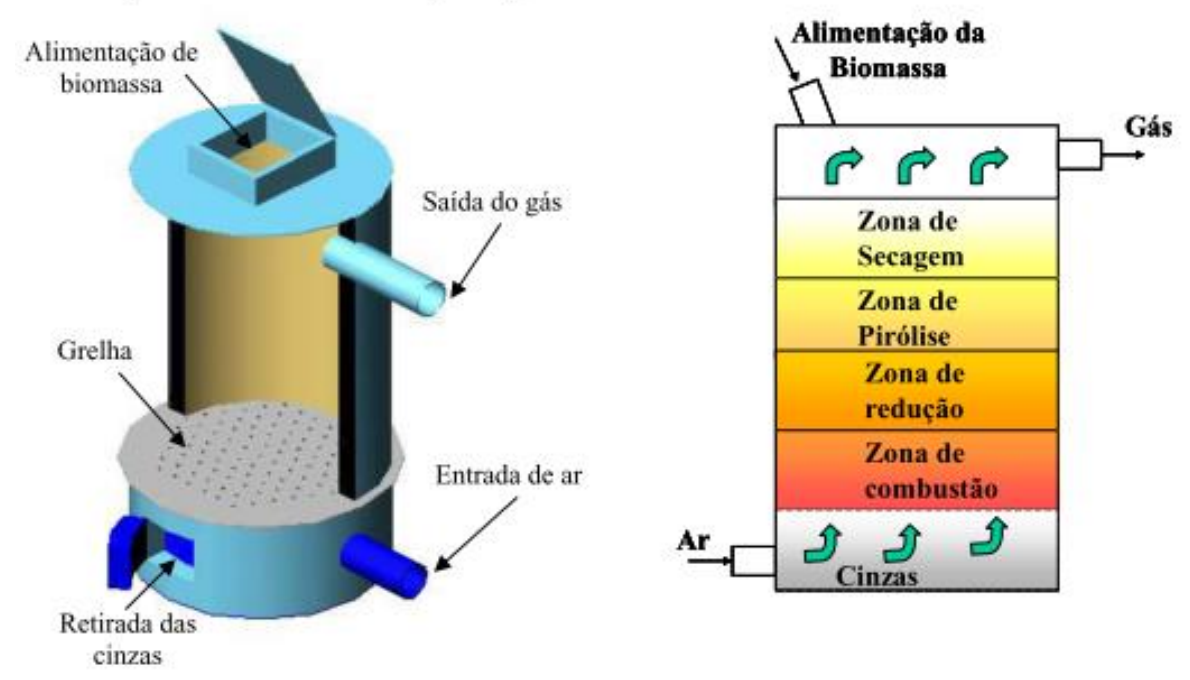

Figura 9- Esquema de um gaseificador contracorrente (ANDRADE, 2007)

Conforme apresentado por Andrade (2007), a biomassa é introduzida e o fluxo de ar aquecido vai de encontro a ela. Na região próxima a grelha ocorre a conversão da matéria orgânica em gás, com a produção de alcatrão. O autor destaca a importância do material componente da grelha ser capaz de suportar altas temperaturas. 


\subsection{Gaseificador concorrente ("downdraft")}

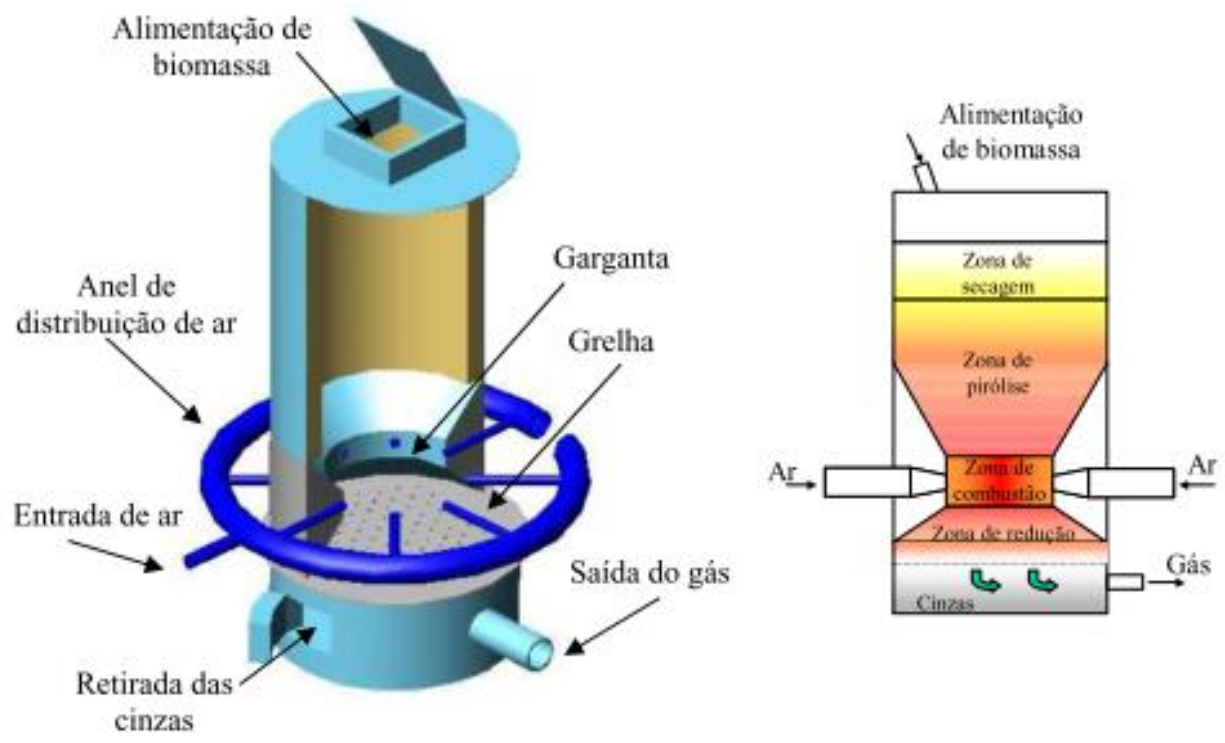

Figura 10 - Esquema de um gaseificador concorrente (ANDRADE, 2007).

Este tipo de gaseificador foi desenvolvido por Jacques Imbert no periodo da segunda guerra mundial. Conforme descrito no diagrama, a biomassa é introduzida pela parte superior, e encontra com o ar. Ambos passarão por zonas de calor, e no local da combustão, onde há um afunilamento (também chamado de garganta cujo propósito é a homogenização da temperatura na região) ocorre a geração do gás a partir da matéria orgânica e simultaneamente o craqueamento (quebra quimica) do alcatrão, reduzindo-o. Após este processo, o gas gerado (mistura de $\mathrm{CO}, \mathrm{H}_{2}, \mathrm{CO}_{2}$ e $\mathrm{H}_{2} \mathrm{O}$ ) é direcionado para baixo, atravessando as cinzas e sendo coletado. $\mathrm{O}$ autor ressalta o correto dimensionamento da garganta é crucial a fim de garantir a eficiência do processo, embora também possa causar o entupimento. Dependendo do tipo de combustível empregado, esta pode ser dispensada. (ANDRADE, 2007) 


\subsection{Gaseificador fluxo cruzado}

\section{("cross flow")}
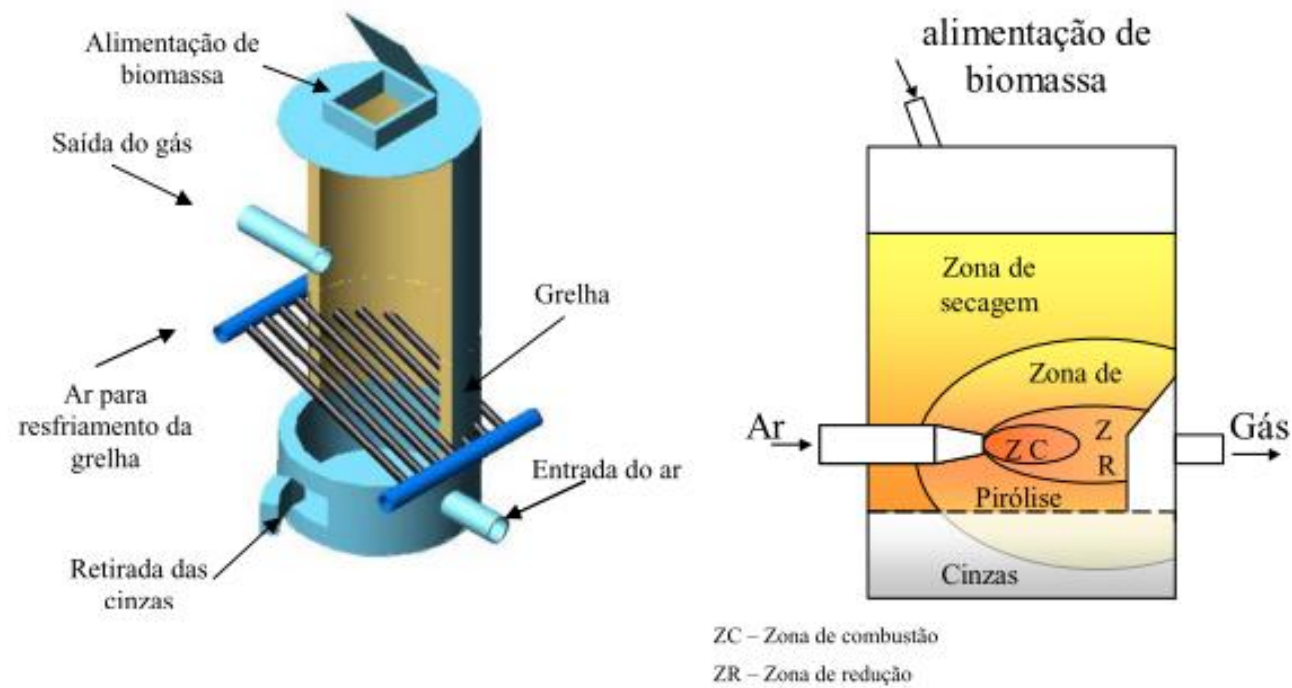

Figura 11 - Esquema de um gaseificador de fluxo cruzado. (ANDRADE, 2007)

Conforme nos descreve Andrade (2007), neste tipo de gaseificador, o fluxo de ar é o requinte tecnológico crucial para o seu funcionamento. Requer biomassa com menor teor de umidade e baixa granulometria. 


\subsection{Gaseificador de leito fluidizado}

\section{("fluidized bed")}

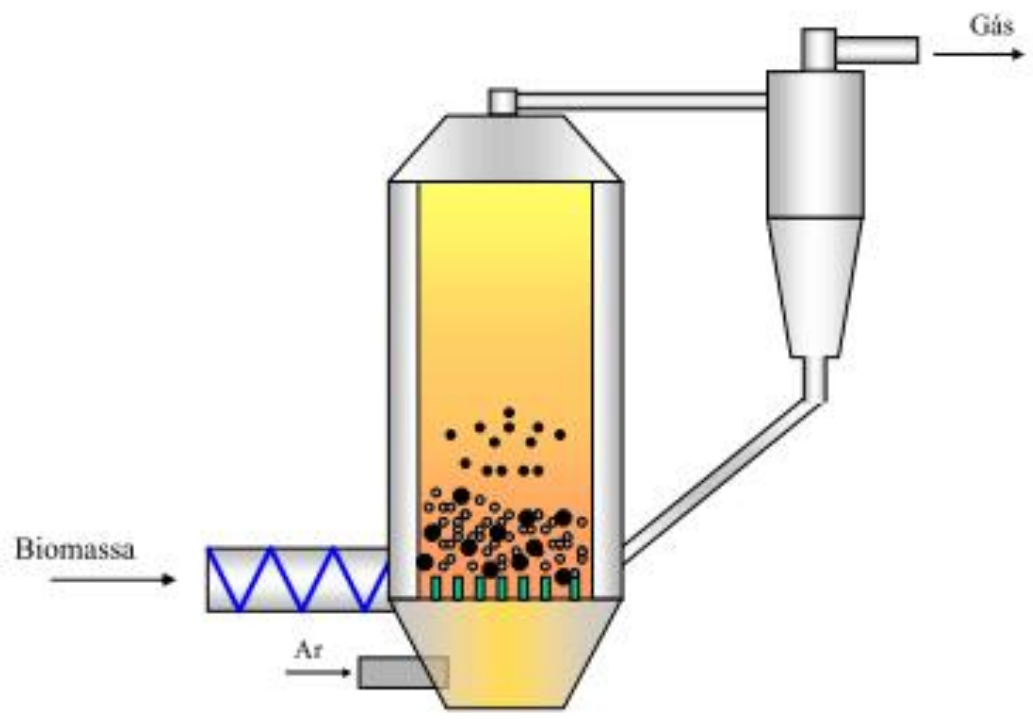

Figura 12 - Esquema de um sistema de gaseificação em leito fluidizado circulante. (ANDRADE, 2007).

Neste tipo de gaseificador, o contato entre a biomassa e o ar é otimizado, proporcionando uma circulação enérgica do particulado culminando numa otimização das reações bem como na uniformização da temperatura. (ANDRADE, 2007)

Utiliza-se areia como substrato (leito) a qual fica em constante suspensão devido a corrente ascendente de ar quente. Tal procedimento promove a queima imediata da biomassa tão logo entre em contato com o fluido. Fatores como o tipo de oxidante (ar ou vapor), a temperatura (entre $700^{\circ} \mathrm{C}$ e $850^{\circ} \mathrm{C}$ ), velocidade superficial, tipo de biomassa e pressão interna do reator (câmara de queima) são cruciais para o funcionamento. (ANDRADE, 2007)

A diferença básica entre os gaseificadores de leito fluidizado circulante e o borbulhante esta na forma de fluidização do leito, no retorno ou não das partículas ao reator e na velocidade de movimentação das partículas. No gaseificador circulante, as velocidades de movimentação do particulado são maiores e este retorna ao reator, diferentemente do gaseificador borbulhante. (ANDRADE, 2007) 


\subsection{Pirólise}

A pirólise é um processo de tratamento térmico sem a presença de oxigênio, onde o calor degrada os resíduos. Este processo quebra gradualmente os compostos presentes nos RSU ao passo que estes atravessam as várias zonas de calor presentes no reator (vertical ou horizontal); a parte inicial deste reator é a zona de secagem, onde a umidade é retirada.

Na região principal do processo, a chamada zona pirolítica (cuja temperatura pode variar de $300^{\circ} \mathrm{C}$ a $1600^{\circ} \mathrm{C}$ ), ocorre à volatilização, oxidação e fusão de vários componentes dos RSU, resultando em gases não condensáveis a base de Nitrogênio e gás de síntese (SYNGAS - gás sintético formado a partir de $\mathrm{CO}_{2}$, hidrocarbonetos, $\mathrm{CO}$ e $\mathrm{H}_{2}$ ). Além desses, também é produzido um liquido chamado pirolenhoso formado principalmente de ácido acético, metanol, alcatrão solúvel e outros compostos em menor quantidade. Além de resíduos sólidos formados por metais, escória e vidros (material não consumido no processo) (LIMA, 1995 apud FEAM, 2013). (figura 14).

Younan et al, 2016 definem pirolise como a conversão da matéria orgânica através do calor e na ausência do oxigênio, resultando em biocombustíveis (bio-oleos, biochar e syngas). Tais produtos tem o potencial econômico e ambiental, pois podem servir como fontes renováveis de energia e redução de emissões de efeito estufa.

A quantidade de subprodutos (fases sólida, líquida e gasosa) vai variar conforme a temperatura (em média, entre $400^{\circ} \mathrm{C}$ e $900^{\circ} \mathrm{C}$ ), da composição dos RSU e do equipamento Utilizado, conforme apresenta Feam (2013). Além de propor que se utilize o SYNGAS para a produção de vapor utilizando-se trocadores de calor. Dependendo de sua composição, ainda pode ser purificado e queimado em turbinas, caldeiras ou motores de combustão interna com o objetivo de gerar energia elétrica ou como matéria prima para a indústria (FEAM, 2013). 


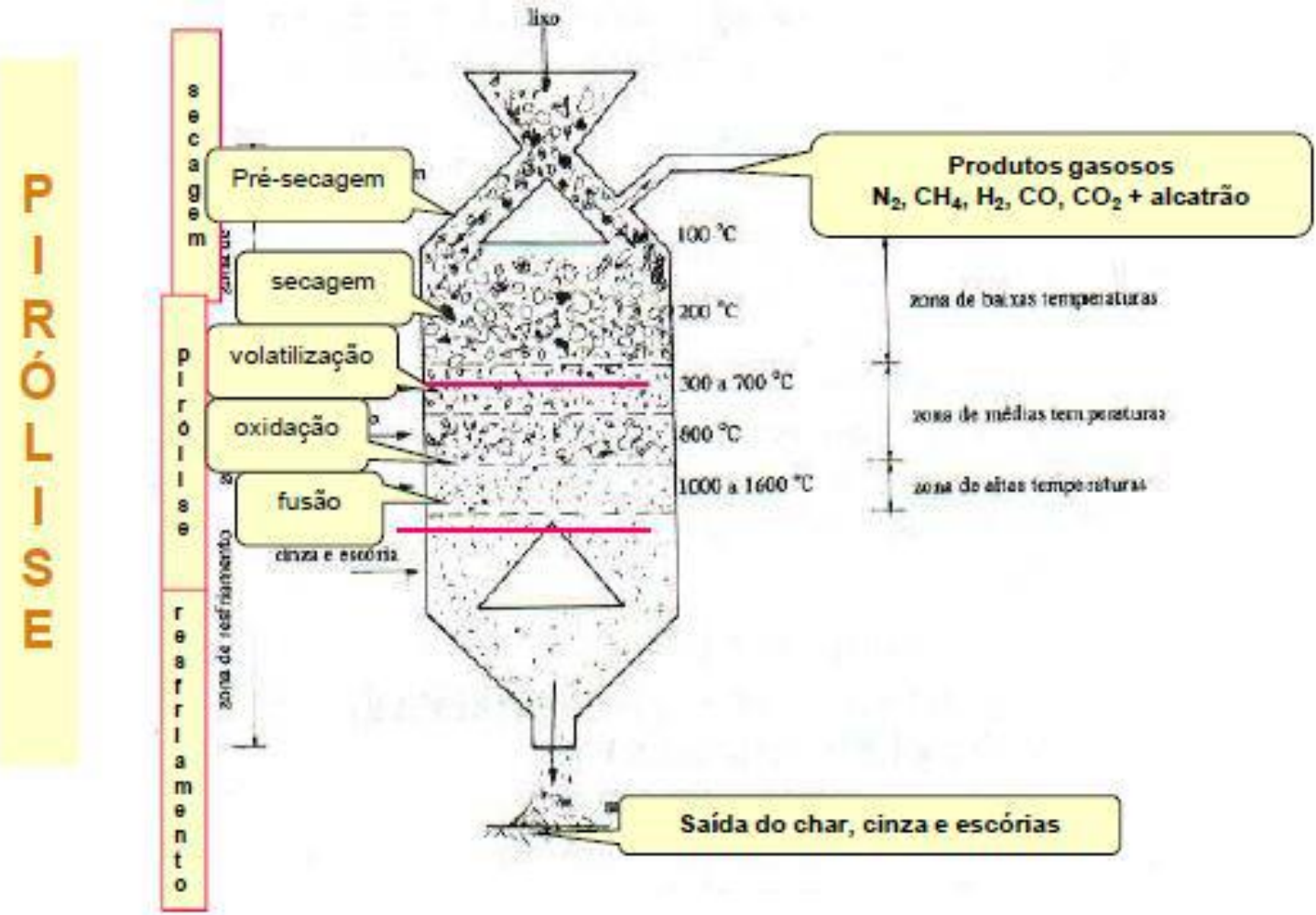

Figura 13 - Diagrama de fluxo do processo no reator pirolítico. Adaptado de LIMA, 1995 apud FEAM, 2013.

As principais vantagens da pirólise são a geração do gas de síntese (syngas) e resíduos sólidos aproveitáveis (CDR), além de menores níveis de emissão de NOx e SO2, além de poder receber insumos (biomassa/RSU) mais heterogêneos. Sendo que esta ultima característica pode afetar a composição do gás de síntese além de diminuir os intervalos de manutenção. Para que este tratamento tenha êxito, é necessária a separação previa de resíduos recicláveis e secagem do material a ser tratado. (Younan et al, 2016).

Conforme apresentam Younan et al, (2016); Chen et al (2015); Duric et al (2014), a este tipo de tratamento é capaz de gerar syngas, bio-óleos (biodiesel por exemplo) e biochar (um combustível sólido).

Feam (2013) já apresenta balanço energético sempre positivo por produzir mais energia que a consumida no processo. Além disso, parâmetros como tempo de retenção, taxa de aquecimento, temperatura, que caracterizam a 
pirolise em 2 tipos: lenta (carbonização) e a rápida. Cada pirolise determina 0 tipo de produto final.

Younan et al (2016) ainda alertam para a falta de informações a respeito de possíveis impactos ambientais, recomendando maiores pesquisas a respeito da cinética das reações (decomposição em fase sólida, e reações cruzadas durante o processo entre as fases solidas, liquida e gasosas dentro do reator) além do dimensionamento do reator.

Para a pirólise rápida, o tempo de retenção é de 0,5 a 2 segundos, temperatura entre $400^{\circ} \mathrm{C}$ e $600^{\circ} \mathrm{C}$ e produz líquido pirolenhoso. Para a pirólise lenta, o tempo de retenção varia de horas a dias, e a temperatura varia de $350^{\circ} \mathrm{C}$ e $700^{\circ} \mathrm{C}$ para produzir resíduos formados por carbono quase puro (Gomes apud FEAM, 2013). A temperatura de operação determina o resultado final do processo.

BROWNSORT (2009) descreve a pirolise lenta como um processo de aquecimento cuja temperatura atinge aos poucos $400^{\circ} \mathrm{C}$ e assim permanece, onde os resíduos permanecem neste ambiente juntamente com o vapor. $\mathrm{O}$ objetivo deste processo é a obtenção de biochar. Embora sejam verificados bioóleos e syngas, geralmente estes são perdidos ou descartados.

As proporções de sólidos, líquidos e gasosos derivados pirolise dos RSU, podem ser vistas na tabela 7:

\begin{tabular}{|c|c|c|c|}
\hline \multirow{2}{*}{$\begin{array}{c}\text { Temperatura } \\
\left({ }^{\circ} \mathrm{C}\right)\end{array}$} & \multicolumn{3}{|c|}{ Percentuais de subprodutos da pirólise (\%) } \\
\cline { 2 - 4 } & gases & líquidos & sólidos \\
\hline 482 & 12,23 & 61,08 & 24,71 \\
\hline 649 & 18,64 & 59,18 & 21,80 \\
\hline 927 & 24,36 & 58,70 & 17,67 \\
\hline
\end{tabular}

Tabela 7 - Efeitos da Temperatura na Pirólise. Fonte: Lima, 1995 apud FEAM, 2013.

Younan et al (2016) realizaram uma investigação experimental a partir da pirolise dos Resíduos Sólidos Municipais, porém, segregou para este fim 
apenas os resíduos de origem vegetal, obtendo 19,97\% de bio-óleo (ou óleo de pirólise), $40,83 \%$ de bio-char e $29,77 \%$ de syngas. Ainda verificaram que quanto maior a quantidade de materiais voláteis compondo os resíduos, maior será o volume de syngas e de modo inversamente proporcional ao volume de biochar.

Esta tecnologia de tratamento requer algumas exigências operacionais, sob a ótica dos parâmetros que afetam a carbonização da madeira para a produção de carvão vegetal (FIGUEIREDO, 2009 apud FEAM, 2013). Tais exigências são vinculadas aos seguintes fatores: i) tipo, umidade, forma e dimensão dos materiais; ii) temperatura final de reação; iii) taxa de aquecimento e tempo de permanência na temperatura final; iv) adição de catalisadores; v)atmosfera de reação (inerte ou parcialmente inerte); vi) técnica utilizada (fonte de energia); vii) qualificação do operador (processos artesanais); viii) pressão ( rendimento e cinética de reações).

\subsection{Arco de Plasma}

De acordo com o estado de agregação da matéria, esta apresenta propriedades peculiares que a caracterizam. Os estados mais conhecidos são 0 estado sólido, liquido e o gasoso. Contudo, após o estado gasoso, onde a agregação molecular é menor, quando aquecido a partir de $3.000^{\circ} \mathrm{C}$, ocorre a remoção de elétrons, ionizando assim o gás.

Este é o $4^{\circ}$ estado da matéria, chamado de plasma (Sun et at, 2013), o qual apresenta boa condutividade elétrica e alta viscosidade Considera-se para que todas as características representativas do plasma estejam presentes, a faixa de temperatura entre $5.000^{\circ} \mathrm{C}$ e $50.000^{\circ} \mathrm{C}$, e $15.000^{\circ} \mathrm{C}$ seja a temperatura padrão de operação desta tecnologia (FEAM, 2010). 
O uso de plasma para a decomposição de resíduos é também conhecido como pirolise a plasma ou queima a plasma, a qual ocorre através de queimadores semelhantes aos utilizados em fornos, com a diferença que neste processo é aplicado um arco voltaico entre um anôdo (polo de carga negativa) e um catodo (polo de carga positiva) com a passagem do gás entres estes polos. A diferença de potencial elétrico entre estes polos cria uma descarga de alta intensidade conhecida como arco. A alimentação destes polos pode ser gerada por corrente alternada (AC) ou corrente continua (DC) (FEAM, 2010).

Sun et at (2013) descrevem o processo ocorrido no reator de plasma ao decompor resíduos como um bombardeamento de elétrons e íons gerados no plasma que são capazes de desestruturar as ligações químicas dos produtos inseridos. Desta forma, as ligações das substancias mais complexas são desfeitas, originando desta forma compostos gasosos mais simples, escória vitrificada, metais entre outros.

Com a projeção deste plasma sobre os resíduos, tem-se as chamadas tochas, as quais podem determinar o tipo de viés tecnológico empregado. Há as tochas de arco transferido e as tochas de arco não transferido. No caso das tochas de arco não transferido, os eletrodos (polos positivo e negativo) estão no interior do dispositivo, dentro do compartimento de onde é projetada a tocha. Nas tochas de arco transferido, um eletrodo fica no interior da tocha de plasma, enquanto o outro fica fora ou esta interligado ao material sob aquecimento. Neste viés tecnológico, a corrente elétrica é contínua. A eficiência de conversão energética é de cerca de $85 \%$ a 90\% (FEAM, 2010). 


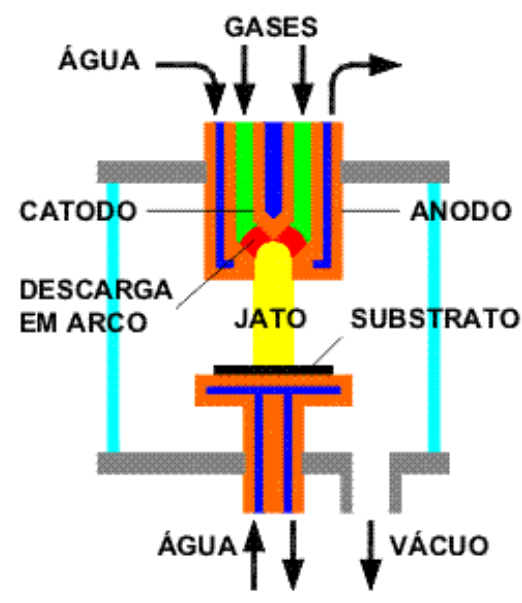

Figura 14 - Fonte: http://www.plasma.inpe.br/LAP_Portal/LAP_Sitio/Texto/Processos_a_Plasma.htm

Nesta tecnologia para tratamento de resíduos, os resíduos sólidos urbanos são introduzidos no sistema através de câmaras estanques chamadas "lock hopper", onde o ar aquecido, que pode ou não conter oxigênio, é introduzido para favorecer a combustão destes resíduos. Após a queima, os resíduos são convertidos em gás combustível e este gás é tratado pela chama de plasma sendo decomposto numa fornalha vertical conhecida como "Shaft". Como produto final, há a produção de hidrogênio e monóxido de carbono e a vitrificação dos compostos inorgânicos (FEAM, 2010).

Como vantagens desta tecnologia, são enumerados o consumo completo da matéria orgânica, a estabilização de compostos inorgânicos de modo semelhante a minerais de alta dureza e a redução do volume dos resíduos em quantidades superiores a 99\% em relação ao original. Já como desvantagens, tem-se o alto custo de investimento, bem como a necessidade de tratamento dos gases gerados. Não há dados consistentes que comprovem e justifiquem seu uso para a remoção de dioxinas e furanos (FEAM, 2010).

Sun et at (2013) relatam e reforçam o uso de plasma para tratamento de resíduos sólidos, principalmente para a destruição de pneus e resíduos plásticos. Corroboram com esta ideia BYUN, Y. et al.(2010) e ISMAIL E ANI (2015). Isso ocorre ao expor os resíduos no reator de plasma (câmara de exposição ao plasma que queima a temperaturas que alcançam 3 milhões de graus), que são convertidos em gás de síntese (a matéria orgânica) o qual pode ser usado para 
a produção de biocombustíveis e escoria vitrificada (substâncias inorgânicas), podendo estes últimos servir de matéria prima na produção de vidro. Consideram ainda que após este tratamento, o nível de emissões atmosféricas é zero. Derivados de enxofre e metais pesados são fixados nas escórias que podem ser recolhidas após o processo. O custo de implantação e o consumo de energia elétrica são as desvantagens deste tratamento.

Segundo o autor (Jonathan Strickland, 2008 apud FEAM, 2010) há duas usinas de queima a plasma, situadas no Japão. Uma no parque industrial de Mihama-Mikata, que trata 24 toneladas de resíduos por dia. A outra, situada na cidade de Utashinai, trata cerca de 300 toneladas de resíduos por dia. Esta tecnologia tem sido utilizada para estabilizar compostos, fundir metais, e recuperação de alguns metais (tal como o Zinco). Já Dodge (2008) relata a queima de 750 toneladas por dia de RSU.

\subsection{OS TRATAMENTOS DE RSU E OS RISCOS À SAÚDE COLETIVA}

Conforma apresentam Siqueira e Moraes (2009) o conceito de saúde coletiva expande e incorpora ao conceito de saúde ambiental a qualidade de vida, o território, e aspectos culturais das populações. Desta maneira, considerar fatores causadores de impactos ambientais numa percepção mais ampla, é um fator determinante a todos os atores envolvidos em cada empreendimento, ação ou desdobramento das necessidades locais. O tratamento de resíduos sólidos urbanos é um fator de relevância às cidades, pois como já visto, aumenta de modo diretamente proporcional ao consumo e ao crescimento populacional, aumentando a pressão no ambiente bem como a demanda por áreas cada vez maiores para a disposição final dos rejeitos.

As tecnologias de tratamento de resíduos sólidos urbanos, trazem consequências ambientais, que se desdobram problemas de saúde coletiva. Os tratamentos de resíduos sólidos urbanos geram emissões atmosféricas, rejeitos 
sólidos e efluentes que demandam atenção por parte dos tomadores de decisão.

O tratamento de resíduos sólidos urbanos por incineração gera em suas emissões atmosféricas dioxinas e furanos. São ricos os relatos na literatura a respeito da geração de Dibenzo-p-dioxinas (PCDD's - polychlorinated Dibenzenodioxin) e Dibenzofuranos policlorados (PCDF's - polychlorinated dibenzofurans) a partir da combustão de RSU. Estas são, segundo Lopes et al (2015), Olie et al (1977) substâncias recalcitrantes. São compostos sabidamente cancerígenos (Gouveia, 2012), (Buekens e Huang, 1998) formados a partir de compostos clorados. Em especial destaque para o composto 2,3,7,8tetraclorodibenzo-p-dioxina (TCDD), que dos 210 tipos de variações de furanos e dioxinas, há 17 tipos que possuem alta toxicidade, e este supra citado, é relacionado como membro mais toxico da família (FEAM, 2012).

Em analises iniciais, Olie et al (1977) notaram grande quantidade de organoclorados retidos no precipitador eletrostáticos dos incineradores de RSU. Buekens e Huang, (1998) confirmam esta análise. McKay (2002) descreve as dioxinas e furanos como os compostos mais tóxicos conhecidos. Possuindo uma natureza apolar, estes compostos são hidrofóbicos, tendo especial afinidade com gorduras e óleos (lipofílicos) e por superfícies lisas. Tais características explicam, segundo o autor, sua presença no solo e em sedimentos. Substâncias de natureza lipídica tendem a fixar e estabilizas estes compostos mesmo em corpos d’água. Sua solubilidade em gorduras aumenta de modo diretamente proporcional ao aumento das concentrações de cloro.

O processo de tratamento de resíduos sólidos urbanos por pirolise pode apresentar riscos a saúde ambiental devido à geração de compostos aromáticos. Tal fato ocorreu a partir do estudo de caso de Lago et al. (2017) ao processar pneus e borrachas. Mesmo que o produto tenha propriedades diferentes, não se pode descartar a composição dos RSU, que possui composição gravimétrica heterogênea. Desta maneira, trata-se de um fator relevante a geração de compostos conhecidos como BTEX (benzeno, tolueno, etilbenzeno e xileno), os quais estão relacionados a efeitos de vão desde enjoos, náuseas, 
vômitos a diarreias, desmaios. E nos casos do benzeno, câncer. Tais características já foram mencionadas por Canellas et al. (2000) ao relatar a presença de compostos aromáticos bem como ácidos graxos ao submeter elementos húmicos oriundos de compostagem à pirolise.

Como resultados da gaseificação, segundo Goulart et al. (1999), de modo similar à pirolise, ocorrem emissões atmosféricas principalmente dos gases $\mathrm{CO}_{2}$ e $\mathrm{N}_{2}$ (maior predominância deste com uma média de 75,6\%) de acordo com os ensaios apresentados. O liquor obtido possui vários compostos aromáticos de grande potencial carcinogênico. As cinzas apresentam concentrações de ZnS (sulfeto de zinco). Embora os tratamentos destes subprodutos sejam viáveis segundo o autor, requerem manutenção e monitoramento constantes.

A queima a plasma dos RSU apresenta a necessidade de lavagem dos gases gerados devido a presença de metais volatilizados como mercúrio e gases ácidos, de acordo com Souza (2014).

Quanto a compostagem, Lima Junior et al. (2017) apresentam como consequência emissão predominante de $\mathrm{CO}_{2}$, com presença discreta de $\mathrm{CH}_{4}$ (quantidade máxima de 2,6\% da composição das emissões) além de alguma presença de moscas. 


\section{RESULTADOS E DISCUSSÃO}

A escolha do método AHP para a elaboração deste trabalho foi baseada na necessidade de elencar, dentre as possibilidades de tratamento de resíduos sólidos urbanos, a mais adequada dentro das alternativas tecnológicas existentes. Além disso, considerando que o método utiliza elementos subjetivos, algumas considerações devem ser feitas a fim de elucidar e minimizar avaliações tendenciosas.

Há várias ferramentas que podem ser aplicadas ao processo decisório. A análise AHP, análise Fuzzy, softwares como os da família PROMETHEE. E escolha da análise AHP se deu baseada tanto na ampla utilização na literatura (Costa, 2002; Paiva e Bueno, S.D.; Perelles, Medeiros e Garcez, 2013; Pereira e Bianchini, 2013; MARCHEZETTI, KAVISKI e BRAGA, 2011; Marins et al, 2012), quanto na possibilidade de se consultar especialistas colaboradores com o fito de obter olhares diversos sobre a mesma situação.

Saaty (2008) apresenta várias aplicações possíveis para esta metodologia: na administração publica realocação de recursos financeiros, realocação de pessoas, em questões industriais e tecnológicas, situações estratégicas e em pesquisa. Como as avaliações são baseadas em comparações, e esta ferramenta é pautada pelos princípios da álgebra linear e cartesiana (DUTRA e FOGLIATTO, 2007; MARINS; SOUZA; BARROS, 2009).

Portanto, inconsistências são constantes, pois refletem a capacidade humana de realizar julgamentos. Saaty (2008) afirma que uma avaliação consistente ou inconsistente é necessariamente resultado de um julgamento, e todo julgamento, mesmo sob um critério, ou pautado por uma escala é necessariamente subjetivo.

Saaty (1990) relaciona o método a um sistema de associação de fatos e valores, a semiótica, onde signos ou significantes (fatos) estão relacionados 
aos significados (valores). Neste contexto, os colaboradores fazem seus julgamentos paritários.

Contudo, a lógica clássica não é capaz de abranger as múltiplas características que são contempladas nas alternativas que eventualmente possam ser consideradas num dado processo decisório, pois é baseada em um sistema binário (verdadeiro ou falso). Menezes (2015) sugere que a metodologia AHP seja tratada dentro de um contexto lógico que aceite tais inconsistências, chamado lógica Paraconsistente. Esta forma de organizar um pensamento está pautada por uma forma de estruturação de pensamento onde as alternativas não neguem as demais, ou melhor dizendo, pelo principio da Não Contradição. $\mathrm{Na}$ realização deste trabalho, a metodologia AHP foi aplicada conforme orientações de Saaty (1990).

Assim, o processo hierárquico de análise (Analytic Hierarchic Process, $\mathrm{AHP}$ ), tem como principais vantagens à definição de prioridades em relação às possibilidades avaliadas no processo decisório. Neste trabalho, a escolha de tecnologias para tratamento de RSU ofereceu duas rotas tecnológicas de duas naturezas diferentes: tratamentos biológicos e tratamentos térmicos.

Como já mencionado, para a aplicação deste método de análise, foi realizada consulta a especialistas nas áreas de tratamento de RSU, e a partir de seus conhecimentos, experiências e sensibilidades, suas ponderações foram obtidas através do preenchimento de formulários (apêndice II), nas quais foram comparadas as tecnologias conforme a natureza do tratamento. Saaty (2008) afirma que, a metodologia pode agregar grupos de avaliação. Todavia, devido a subjetividade e experiência de cada avaliador, há a necessidade de traçar-se uma média entre os valores obtidos. Não importando o numero de avaliadores especialistas consultados, a média geométrica dos resultados finais deve ser calculada, mesmo para o caso dos critérios possuírem pesos diferentes para cada avaliador.

Outro fator que contribuiu para a escolha da ferramenta foi a disponibilidade imediata para a sua aplicação. Este trabalho de revisão utilizou-a a partir 
do software de planilhas eletrônicas EXCEL 2010, bastando apenas estruturar as planilhas e inserir os valores gerados a partir dos formulários preenchidos pelos colaboradores especialistas.

Como já apresentado, metodologia AHP descrita por Saaty (1990) necessita que as avaliações paritárias sejam realizadas a partir de consulta a especialistas que estejam familiarizados com as questões apresentadas. Neste caso, foram consultados especialistas na área de tratamento de resíduos sólidos urbanos que atuaram como colaboradores da pesquisa.

Como esta metodologia leva em consideração a percepção do usuário quanto a hierarquia de prioridades ao se tomar uma decisão, uma determinada alternativa pode ter sub-níveis de importância (SAATY, 1977; 2008). Neste trabalho, por exemplo, foram considerados critérios de avaliação focados no custo. Como reconhecido nesta metodologia, a capacidade humana de percepção e avaliação é subjetiva, ou melhor dizendo, não há um critério puramente matemático na avaliação, o que pode gerar distorções nos julgamentos. Esta condição é reconhecida como inconsistência. Tal condição pode sugerir análises tendenciosas, ou até mesmo, avaliações equivocadas, superestimadas ou subestimadas (ocorre quando não há uma relação proporcional entre suas avaliações). Isso se evidencia na atribuição de pesos em relação a importância de algum fatores ou elementos que influenciem a avaliação. Valores superestimados ou subestimados geram inconsistências ao final. Esta é uma desvantagem desta ferramenta. Todavia, isso pode ser corrigido com a consulta de mais de um especialista e através da análise de consistência que a própria ferramenta apresenta.

Como as avaliações são baseadas em comparações, e esta ferramenta é pautada pelos princípios da álgebra linear e cartesiana (Dutra e Fogliatto, 2007; MARINS; SOUZA; BARROS, 2009). Portanto, inconsistências são constantes, pois refletem a capacidade humana de realizar julgamentos. Saaty (2008) afirma que uma avaliação consistente ou inconsistente é necessariamente resultado de um julgamento, e todo julgamento, mesmo sob um critério, ou pautado por uma escala é necessariamente subjetivo. 
Saaty (1997) define consistência como a representação de um problema real dentro de uma escala. Portanto, uma avaliação consistente está relacionada com uma condição real numa proporção representativa. E desta forma, uma inconsistência é uma situação que não tem aderência à realidade. Assim, uma relação linear onde uma alternativa $A$ é 2 vezes melhor que $B$, e $B$ é 3 vezes melhor que $C$, então $A$, necessariamente, deve ser 6 melhor que $C$ (Menezes, 2015). Isso pode ser considerada uma avaliação consistente dentro desta metodologia. Como a ferramenta AHP considera a inconsistência humana no processo de avaliação, ela se submete a um sistema lógico.

Assim, com os formulários (Apêndice II), a consulta foi realizada. Foram agrupadas as tecnologias de tratamento de resíduos sólidos municipais ou urbanos conforme sua natureza: tratamento térmico e tratamento biológico.

Como os resíduos sólidos gerados nas cidades possuem uma composição gravimétrica variada, tendo em sua composição substâncias orgânicas putrescíveis e materiais inorgânicos e orgânicos não putrescíveis, a opção de tratamento biológico necessariamente está associada ao tratamento térmico, posto que o primeiro grupo de tecnologias não afeta as substâncias não putrescíveis.

Já o tratamento térmico, por possuir alternativas tecnológicas que permitam o tratamento de ambas as substâncias, i.e., orgânicos e inorgânicos, pode ser considerada a sua utilização de modo combinado com outras tecnologias ou de modo independente.Uma questão preponderante para a aplicação desta metodologia é a determinação de uma escala de importância entre os critérios. A determinação da importância dos critérios também é realizada de modo paritário. Contudo, de modo a evitar que as avaliações pudessem ser tendenciosas, inclinadas conforme a área de formação do colaborador, determinou-se que a importância de ambos os critérios tivessem o mesmo peso, i.e., iguais.

Saaty (2008) estabelece 4 etapas para o processo decisório em sua metodologia AHP, que podem ser compreendidos como 1- definição do problema 
e definição das possibilidades de resolução; 2 - determinar a hierárquica tendo como nível mais alto a resolução do problema definido; 3 - construção das matrizes alimentadas pelas comparações paritárias e 4 - aplicação dos pesos atribuídos a cada uma das alternativas e a determinação das prioridades como resultado de cada nível hierárquico.

De modo similar, MARCHEZETTI, KAVISKI e BRAGA (2011) aplicaram esta metodologia para hierarquizar as formas de tratamento de RSU. Organizam a aplicação da metodologia em 4 etapas: $1^{\text {a }}$ Etapa: identificação das alternativas tecnológicas disponíveis para o tratamento dos resíduos sólidos; $2^{\mathrm{a}}$ Etapa: estabelecimento de critérios para a hierarquização. $3^{\mathrm{a}}$ Etapa: aferir pesos aos critérios propostos para cada alternativa tecnológica disponível para o tratamento dos resíduos sólidos domiciliares; e 4⿳亠丷厂 Etapa: definição da escala hierárquica para as alternativas tecnológicas disponíveis para o tratamento dos resíduos sólidos.

Assim, temos a $1^{\underline{a}}$ e a $2^{\underline{a}}$ etapas definidas na figura 16.

QUAL MELHOR TECNOLOGIA PARA TRATAMENTO DE RESÍDUOS SÓLIDOS?

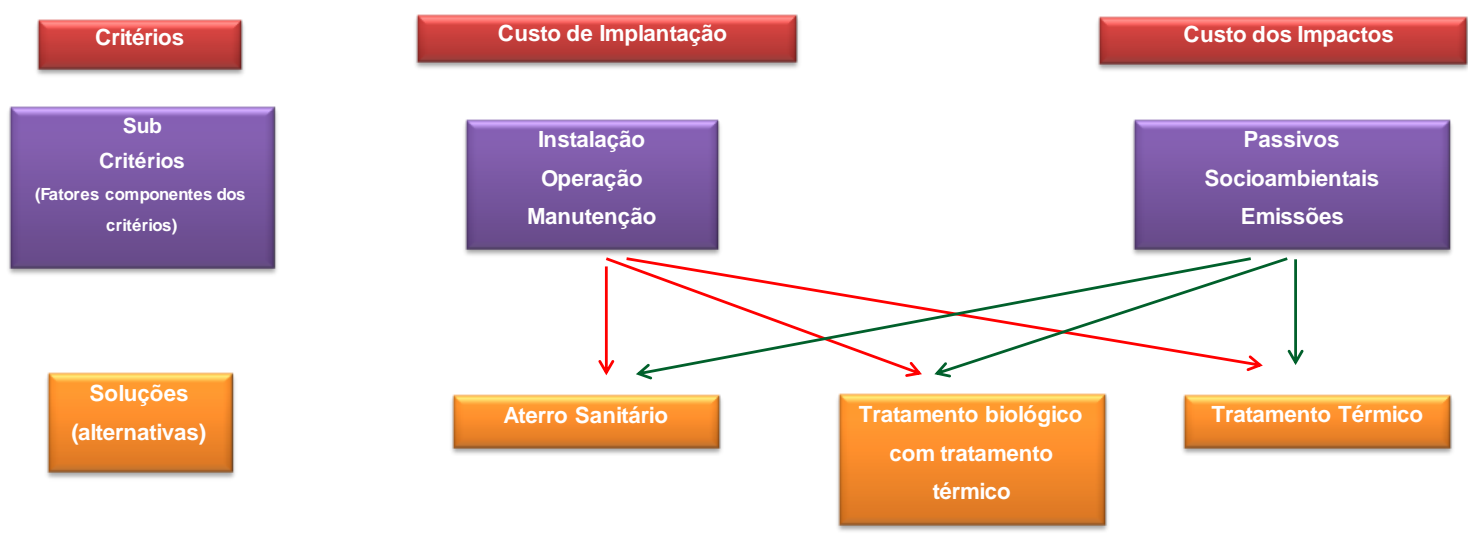

Figura 15 - Hierarquia da escolha.

De modo a evitar muitas variáveis que pudessem impactar nos custos, que seriam causados pelo aumento de sub-níveis, os subcritérios que comporiam os Custos Internos e dos impactos foram considerados, mas aglutinados na interpretação. Um número muito grande de variáveis afeta a qualidade das ava- 
liações por parte dos colaboradores, posto que, realizar muitas comparações pareadas demanda muito esforço dos colaboradores, podendo causar equívocos devido a fadiga. Desta forma, a racionalização das opções é uma consequência necessária a fim de evitar erros (DUTRA e FOGLIATTO, 2007).

Assim, o método AHP pode ser otimizado de modo a facilitar a tomada de decisão. Como definido por Menezes (2015), para tomar uma decisão requer a identificação do problema, estabelecer critérios e ordenar as alternativas que possam satisfazer as necessidades e avaliar a eficácia da decisão.

O custo de logística foi considerado na avaliação, contudo já é um elemento presente na atualidade. A segregação dos resíduos em sua origem é fator determinante para que as alternativas tecnológicas sejam aplicadas com sucesso, como evidenciado por Silva e Silva (2012), Khalid et al (2011) Ebner et al (2016) no uso de biodigestores e Bidone (2001), Oviedo et al (2015), Pan, Dam e Sen (2011) no uso de compostagem onde em ambos, somente a materia orgânica é afetada por estes processos.

Logo, o Custo de Logística foi considerado a partir da segregação na origem do resíduo, o que resultaria na possibilidade aplicação dos tratamentos expostos neste trabalho ou com a não segregação na origem, o terminaria impactando negativamente (e de modo geral, inviabilizando) nas possibilidades de tratamento apresentadas, limitando-as a poucas alternativas.

Assim, a análise das alternativas tecnológicas sob a ótica dos Custos Internos (custos relativos a implantação, operação e manutenção dos empreendimentos) e Custo Externos (Custos Externos relativos aos tratamentos, incluindo os custos dos impactos sociais, ambientais, das emissões e dos passivos) considerados como critérios centrais desta avaliação, dentro da análise AHP.

De modo geral, o custo pode ser determinado a partir de vários fatores, tais como custo energético, custo de transporte, custo de armazenamento, cus- 
to de ações mitigadoras. Neste trabalho, os custos foram considerados a partir da experiência dos colaboradores.

Para comparação destes critérios, foram atribuídos valores, que foram utilizados pelos colaboradores a fim de realizar a $3^{\underline{a}}$ etapa proposta por Saaty (2008) conforme a sensibilidade dos colaboradores. Esta escala é apresentada na tabela 8.

\begin{tabular}{|l|c|}
\hline Absolutamente superior & 9 \\
\hline Expressivamente Superior & 7 \\
\hline Moderadamente superior & 5 \\
\hline Levemente Superior & 3 \\
\hline Equivalente & 1 \\
\hline \multicolumn{2}{|l|}{ Tabela 8 - Valores dos AHP (SAATY, 2008) }
\end{tabular}

Por se tratar de uma avaliação de custos, fica evidenciado que valores maiores definem custos maiores quando comparadas as vias tecnológicas (Tratamento Biológico e Tratamento Térmico) e o uso atual dos Aterros Sanitários.

Para a determinação das importâncias, ou melhor dizendo, qual dos critérios tem maior relevância (maior peso) nesta avaliação, foram atribuídos igual importância ao custo de implantação e custo dos impactos socioambientais, de forma a verificar, de acordo com a percepção dos colaboradores, qual via tecnológica se destaca como sendo a de menor custo geral. Portanto, foi atribuído peso 1 para cada um dos critérios (SAATY, 2008). Os resultados obtidos pela metodologia revelam a $4^{\mathrm{a}}$ etapa.

\begin{tabular}{|l|c|c|}
\hline \multicolumn{3}{|c|}{ IMPORTÂNCIA DOS CRITÉRIOS À } \\
LUZ FOCO PRINCIPAL \\
\hline & $\begin{array}{c}\text { Custos de } \\
\text { Implantação }\end{array}$ & $\begin{array}{c}\text { Custos dos } \\
\text { Impactos }\end{array}$ \\
\hline Custos de Implantação & 1 & 1 \\
\hline Custos dos Impactos & 1 & 1 \\
\hline
\end{tabular}

Tabela 9 - Importância AHP (SAATY, 2008). 


\subsection{RESULTADOS}

Após o recebimento dos formulários preenchidos (tabela 10), os dados foram transcritos conforme o método AHP exige. Assim, foram montadas matrizes para os critérios CUSTO DE IMPLANTAÇÃO e CUSTOS DOS IMPACTOS SOCIOAMBIENTAIS, avaliando aos pares cada uma das alternativas apresentadas como soluções viáveis para tratar os resíduos sólidos urbanos, que foram agrupadas como Aterro Sanitário (AS), Tratamento Biológico e Tratamento Térmico com segregação de resíduos (TB+TT) e Tratamento Térmico sem segregação de resíduos (TT).

Dos formulários preenchidos a partir da consulta aos especialistas colaboradores, num total de 7 (sete), foram obtidos os julgamentos conforme tabela 10.

\begin{tabular}{|c|c|c|c|c|c|c|c|c|c|}
\hline \multicolumn{5}{|c|}{ Custos de Implantação } & \multicolumn{5}{|c|}{ Custos dos Impactos } \\
\hline & & Aterro Sanitário & $\begin{array}{c}\text { Tratamento } \\
\text { Biológico + } \\
\text { Tratamento } \\
\text { Térmico } \\
\end{array}$ & $\begin{array}{c}\text { Tratamento } \\
\text { Térmico }\end{array}$ & & & Aterro Sanitário & $\begin{array}{c}\text { Tratamento } \\
\text { Biológico + } \\
\text { Tratamento } \\
\text { Térmico } \\
\end{array}$ & $\begin{array}{c}\text { Tratamento } \\
\text { Térmico }\end{array}$ \\
\hline Especialista 1 & \multirow{7}{*}{ Aterro Sanitário } & 1 & 7 & 9 & Especialista 1 & \multirow{7}{*}{ Aterro Sanitário } & 1 & $1 / 5$ & 7 \\
\hline Especialista 2 & & 1 & $1 / 7$ & $1 / 7$ & Especialista 2 & & 1 & 7 & $1 / 7$ \\
\hline Especialista 3 & & 1 & 5 & 7 & Especialista 3 & & 1 & $1 / 3$ & 1 \\
\hline Especialista 4 & & 1 & $1 / 7$ & $1 / 7$ & Especialista 4 & & 1 & 9 & 9 \\
\hline Especialista 5 & & 1 & $1 / 7$ & $1 / 9$ & Especialista 5 & & 1 & 3 & 3 \\
\hline Especialista 6 & & 1 & $1 / 5$ & $1 / 3$ & Especialista 6 & & 1 & $1 / 7$ & $1 / 5$ \\
\hline Especialista 7 & & 1 & 5 & $1 / 3$ & Especialista 7 & & 1 & 9 & 5 \\
\hline Especialista 1 & \multirow{7}{*}{$\begin{array}{c}\text { Tratamento } \\
\text { Biológico + } \\
\text { Tratamento } \\
\text { Térmico }\end{array}$} & $1 / 7$ & 1 & 7 & Especialista 1 & \multirow{7}{*}{$\begin{array}{c}\text { Tratamento } \\
\text { Biológico + } \\
\text { Tratamento } \\
\text { Térmico }\end{array}$} & 5 & 1 & $1 / 5$ \\
\hline Especialista 2 & & 7 & 1 & $1 / 7$ & Especialista 2 & & $1 / 7$ & 1 & $1 / 7$ \\
\hline Especialista 3 & & $1 / 5$ & 1 & 3 & Especialista 3 & & 3 & 1 & 5 \\
\hline Especialista 4 & & 7 & 1 & 7 & Especialista 4 & & $1 / 9$ & 1 & $1 / 5$ \\
\hline Especialista 5 & & 7 & 1 & $1 / 7$ & Especialista 5 & & $1 / 3$ & 1 & $1 / 3$ \\
\hline Especialista 6 & & 5 & 1 & 5 & Especialista 6 & & 7 & 1 & 7 \\
\hline Especialista 7 & & $1 / 5$ & 1 & $1 / 7$ & Especialista 7 & & $1 / 9$ & 1 & $1 / 5$ \\
\hline Especialista 1 & \multirow{7}{*}{$\begin{array}{l}\text { Tratamento } \\
\text { Térmico }\end{array}$} & $1 / 9$ & $1 / 7$ & 1 & Especialista 1 & \multirow{7}{*}{$\begin{array}{c}\text { Tratamento } \\
\text { Térmico }\end{array}$} & $1 / 7$ & 5 & 1 \\
\hline Especialista 2 & & 7 & 7 & 1 & Especialista 2 & & 7 & 7 & 1 \\
\hline Especialista 3 & & $1 / 7$ & $1 / 3$ & 1 & Especialista 3 & & 1 & $1 / 5$ & 1 \\
\hline Especialista 4 & & 7 & $1 / 7$ & 1 & Especialista 4 & & $1 / 9$ & 5 & 1 \\
\hline Especialista 5 & & 9 & 7 & 1 & Especialista 5 & & $1 / 3$ & 3 & 1 \\
\hline Especialista 6 & & 3 & $1 / 5$ & 1 & Especialista 6 & & 5 & $1 / 7$ & 1 \\
\hline Especialista 7 & & 3 & 7 & 1 & Especialista 7 & & $1 / 5$ & 5 & 1 \\
\hline
\end{tabular}

Tabela 10 - Resultado da avaliação (Apêndice III).

Como exemplo, tem-se uma matriz formada a partir do formulário preenchido por um dos colaboradores (colaborador especialista 3), conforme apresentado na tabela 11. 


\begin{tabular}{|c|c|c|c|c|c|c|c|}
\hline \multicolumn{4}{|c|}{ Custos de Implantação } & \multicolumn{4}{|c|}{ Custos dos Impactos } \\
\hline & $\begin{array}{c}\text { Aterro } \\
\text { Sanitário }\end{array}$ & $\begin{array}{c}\text { Tratamento } \\
\text { Biológico + } \\
\text { Tratamento } \\
\text { Térmico }\end{array}$ & $\begin{array}{c}\text { Tratamento } \\
\text { Térmico }\end{array}$ & & $\begin{array}{c}\text { Aterro } \\
\text { Sanitário }\end{array}$ & $\begin{array}{c}\text { Tratamento } \\
\text { Biológico + } \\
\text { Tratamento } \\
\text { Térmico }\end{array}$ & $\begin{array}{c}\text { Tratamento } \\
\text { Térmico }\end{array}$ \\
\hline $\begin{array}{c}\text { Aterro } \\
\text { Sanitário }\end{array}$ & 1 & 5 & 7 & $\begin{array}{c}\text { Aterro } \\
\text { Sanitário }\end{array}$ & 1 & $1 / 3$ & 1 \\
\hline $\begin{array}{c}\text { Tratamento } \\
\text { Biológico + } \\
\text { Tratamento } \\
\text { Térmico }\end{array}$ & $1 / 5$ & 1 & 3 & $\begin{array}{c}\text { Tratamento } \\
\text { Biológico + } \\
\text { Tratamento } \\
\text { Térmico }\end{array}$ & 3 & 1 & 5 \\
\hline $\begin{array}{c}\text { Tratamento } \\
\text { Térmico }\end{array}$ & $1 / 7$ & $1 / 3$ & 1 & $\begin{array}{c}\text { Tratamento } \\
\text { Térmico }\end{array}$ & 1 & $1 / 5$ & 1 \\
\hline
\end{tabular}

Tabela 11 - Matriz formada a partir de formulário preenchido (colaborador especialista 3).

Após esta etapa, cada coluna teve seus respectivos elementos somados, para que cada um destes tivesse seu resultado dividido pelo valor da soma de sua coluna, a fim de homogeneizar os valores num processo conhecido como normalização (Tabela 12) (SAATY,1977; 2008; Costa, 2002; MARCHEZETTI, KAVISKI e BRAGA, 2011) .

\begin{tabular}{|c|c|c|c|}
\hline \multicolumn{4}{|c|}{ Custos de Implantação } \\
\hline & $\begin{array}{c}\text { Aterro } \\
\text { Sanitário }\end{array}$ & $\begin{array}{c}\text { Tratamento } \\
\text { Biológico + } \\
\text { Tratamento } \\
\text { Térmico }\end{array}$ & $\begin{array}{c}\text { Tratamento } \\
\text { Térmico }\end{array}$ \\
\hline $\begin{array}{c}\text { Aterro } \\
\text { Sanitário }\end{array}$ & 0,745 & 0,789 & 0,636 \\
\hline $\begin{array}{c}\text { Tratamento } \\
\text { Biológico + } \\
\text { Tratamento } \\
\text { Térmico }\end{array}$ & 0,149 & 0,158 & 0,273 \\
\hline $\begin{array}{c}\text { Tratamento } \\
\text { Térmico }\end{array}$ & 0,106 & 0,053 & 0,091 \\
\hline
\end{tabular}

\begin{tabular}{|c|c|c|c|}
\hline \multicolumn{4}{|c|}{ Custos dos Impactos } \\
\hline & $\begin{array}{c}\text { Aterro } \\
\text { Sanitário }\end{array}$ & $\begin{array}{c}\text { Tratamento } \\
\text { Biológico }+ \\
\text { Tratamento } \\
\text { Térmico }\end{array}$ & $\begin{array}{c}\text { Tratamento } \\
\text { Térmico }\end{array}$ \\
\hline $\begin{array}{c}\text { Aterro } \\
\text { Sanitário }\end{array}$ & 0,200 & 0,217 & 0,143 \\
\hline $\begin{array}{c}\text { Tratamento } \\
\text { Biológico + } \\
\text { Tratamento } \\
\text { Térmico }\end{array}$ & 0,600 & 0,652 & 0,714 \\
\hline $\begin{array}{c}\text { Tratamento } \\
\text { Térmico }\end{array}$ & 0,200 & 0,130 & 0,143 \\
\hline
\end{tabular}

Tabela 12 - Matrizes normalizadas.

Com este procedimento, pode-se calcular a chamada Prioridade Média Local para cada uma das alternativas (soluções ou vias tecnológicas possíveis). Para tanto, deve-se calcular as médias de cada linha. Logo, as prioridades médias locais para este formulário estão apresentados na tabela 13. 


\begin{tabular}{|c|c|}
\hline $\begin{array}{c}\text { Prioridade Média Local } \\
\text { Custo de Implantação }\end{array}$ & $\begin{array}{c}\text { Prioridade Média Local } \\
\text { Custo dos Impactos } \\
\text { Socioambientais }\end{array}$ \\
\hline 0,724 & 0,187 \\
\hline 0,193 & 0,655 \\
\hline 0,083 & 0,158 \\
\hline
\end{tabular}

Tabela 13 - Prioridade Média Local para cada alternativa segundo cada critério utilizado (SAATY, 2008).

É imprescindível fazer o mesmo procedimento para a matriz construída a partir da Importância dos Critérios à luz do Foco Principal, que para este trabaIho foi atribuída igual importância ou relevância tanto para os Custos de Implantação das soluções tecnológicas (foco econômico) quanto para os Custos Socioambientais, conforme apresentado na tabela 14 .

\begin{tabular}{|c|c|c|}
\hline \multicolumn{3}{|c|}{$\begin{array}{c}\text { IMPORTÂNCIA DOS CRITÉRIOS À } \\
\text { LUZ FOCO PRINCIPAL }\end{array}$} \\
\hline & $\begin{array}{l}\text { Custos de } \\
\text { Implantação }\end{array}$ & $\begin{array}{l}\text { Custos dos } \\
\text { Impactos Socio- } \\
\text { ambientais }\end{array}$ \\
\hline Custos de Implantação & 1 & 1 \\
\hline Custos dos Impactos & 1 & 1 \\
\hline
\end{tabular}

A Prioridade Média Local da Importância dos Critérios à luz do Foco Principal foi de 0,5 para ambos os critérios (tabela 15).

\begin{tabular}{|c|c|c|}
\hline \multicolumn{3}{|c|}{$\begin{array}{c}\text { IMPORTÂNCIA DOS CRITÉRIOS À } \\
\text { LUZ FOCO PRINCIPAL }\end{array}$} \\
\hline & $\begin{array}{c}\text { Custos de } \\
\text { Implantação }\end{array}$ & $\begin{array}{c}\text { Custos dos } \\
\text { Impactos Socio- } \\
\text { ambientais }\end{array}$ \\
\hline Custos de Implantação & 0,500 & 0,500 \\
\hline Custos dos Impactos & 0,500 & 0,500 \\
\hline
\end{tabular}

Tabela 15 - Valores normalizados. 
Por fim, para calcular a chamada Prioridade Média Global, é necessário que sejam somados os produtos das Prioridades Médias Locais de cada alternativa (solução) com o valor das Prioridades Médias Locais da matriz de Importância dos Critérios à luz do Foco Principal, conforme descrito abaixo na tabela 16.

\begin{tabular}{|c|c|c|c|c|}
\hline & $\begin{array}{c}\text { Prioridade Média } \\
\text { Local } \\
\text { Custo de Implanta- } \\
\text { ção }\end{array}$ & $\begin{array}{c}\text { Prioridade Média } \\
\text { Local } \\
\text { Custo dos Impactos } \\
\text { Socioambientais }\end{array}$ & $\begin{array}{c}\text { Importância Dos } \\
\text { Critérios À } \\
\text { Luz Foco Principal }\end{array}$ & $\begin{array}{c}\text { Prioridade Média } \\
\text { Global }\end{array}$ \\
\hline Aterro Sanitário & 0,724 & 0,187 & 0,5 & 0,455 \\
\hline $\begin{array}{c}\text { Tratamento Biológico }+ \\
\text { Tratamento Térmico }\end{array}$ & 0,193 & 0,655 & 0,5 & 0,424 \\
\hline Tratamento Térmico & 0,083 & 0,158 & 0,121 \\
\hline
\end{tabular}

Tabela 16 - Resultados da avaliação de um especialista conforma a metodologia, onde o valor menor indica a alternativa de menor custo.

De forma Resumida, pode-se compreender de modo geral, a escolha que trará o menor custo seria a de menor valor. Pode-se compreender então, que a partir das consultas aos especialistas, suas experiências e opiniões técnicas apontam para soluções de menor custo.

Para considerar as avaliações dentro desta metodologia, deve-se calcular o nível de consistência da avaliação (SAATY, 2008). Para tanto, é necessário determinar o chamado Índice de Consistência (IC), que é descrito a partir da fórmula abaixo:

$$
\frac{\lambda m a ́ x-n}{n-1}
$$

Onde o $\lambda$ máx é calculado a partir das prioridades médias locais, onde seus valores respectivos às alternativas são multiplicados pela soma de cada coluna da matriz de critérios. E o valor de $\boldsymbol{n}$ é a quantidade de alternativas avaliadas.

Neste caso, multiplicaram-se os valores de Prioridade Média Local sob a ótica dos custos de Implantação de cada alternativa $(\mathrm{AS}=0,724$, TB+TT $=$ 0,193 e TT $=0,083$ ) pela soma de cada coluna da Matriz de Custos de Implantação $(1,343 ; 6,333$ e 11) da seguinte forma: 


$$
\lambda \text { máx }=\left(0,724^{*} 1,343\right)+\left(0,193^{*} 6,333\right)+\left(0,083^{*} 11\right) \text {. }
$$

Obtendo-se o $\lambda$ máx $=3,107$. Assim, aplicando-se a formula, tem-se:

$$
\mathrm{IC}=\frac{3,107-3}{3-1}=0,05 \text {. }
$$

A literatura referente ao método AHP se refere ao chamado Índice Randômico de Consistência (IR) (tabela 17) que está relacionado a quantidade de variáveis (alternativas) utilizadas na avaliação (SAATY, 1997; 2008; Costa, 2002; AYAG, 2005; Braga, 2011). Assim, tem-se a seguinte relação:

\begin{tabular}{|c|c|c|c|c|c|c|c|c|c|}
\hline $\boldsymbol{n}$ & 1 & 2 & 3 & 4 & 5 & 6 & 7 & 8 & 9 \\
\hline IR & 0,00 & 0,00 & 0,58 & 0,90 & 1,12 & 1,24 & 1,32 & 1,41 & 1,45 \\
\hline \multicolumn{7}{|c|}{ Tabela 17 - İndice Randômico de Consistência (IR). }
\end{tabular}

Para obter-se o nível de consistência da avaliação, deve ser calculada a Razão de Consistência (RC) através da formula:

$$
R C=\frac{I C}{I R}
$$

O resultado necessariamente deve ser inferior a 0,1 ou $10 \%$. Caso seja superior, a metodologia orienta a refazer a avaliação ou descartá-la. Neste caso, o RC= 0,09 ou $9 \%$. Portanto, trata-se de uma avaliação consistente.

A partir dos formulários recebidos, chegou-se aos resultados apresentados no gráfico 1. 


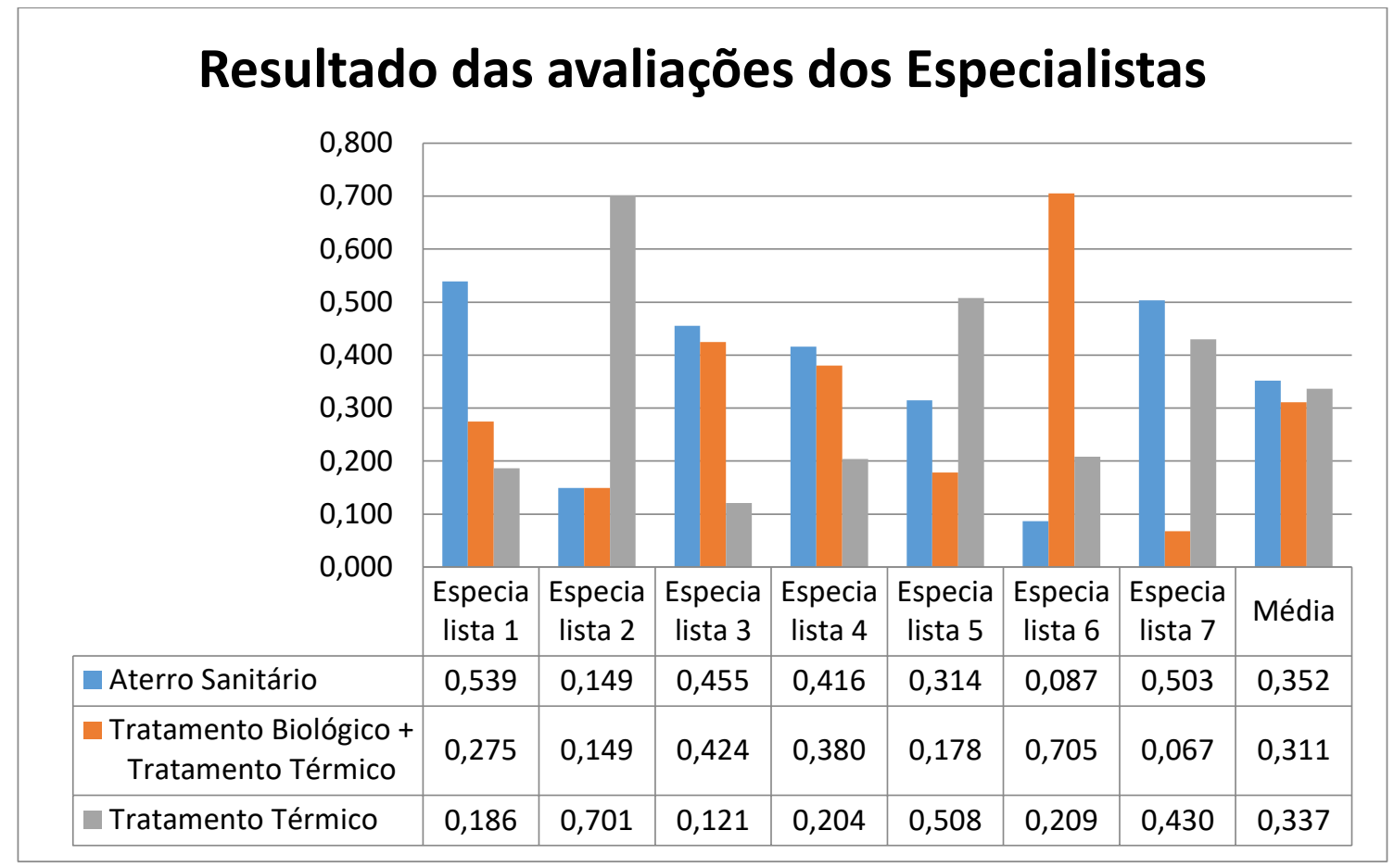

Gráfico 1 - Consolidação das avaliações.

Todavia, após a aplicação dos testes de consistência a partir das avaliações dos colaboradores, apenas duas se mantiveram consistentes, conforme 0 gráfico 2.

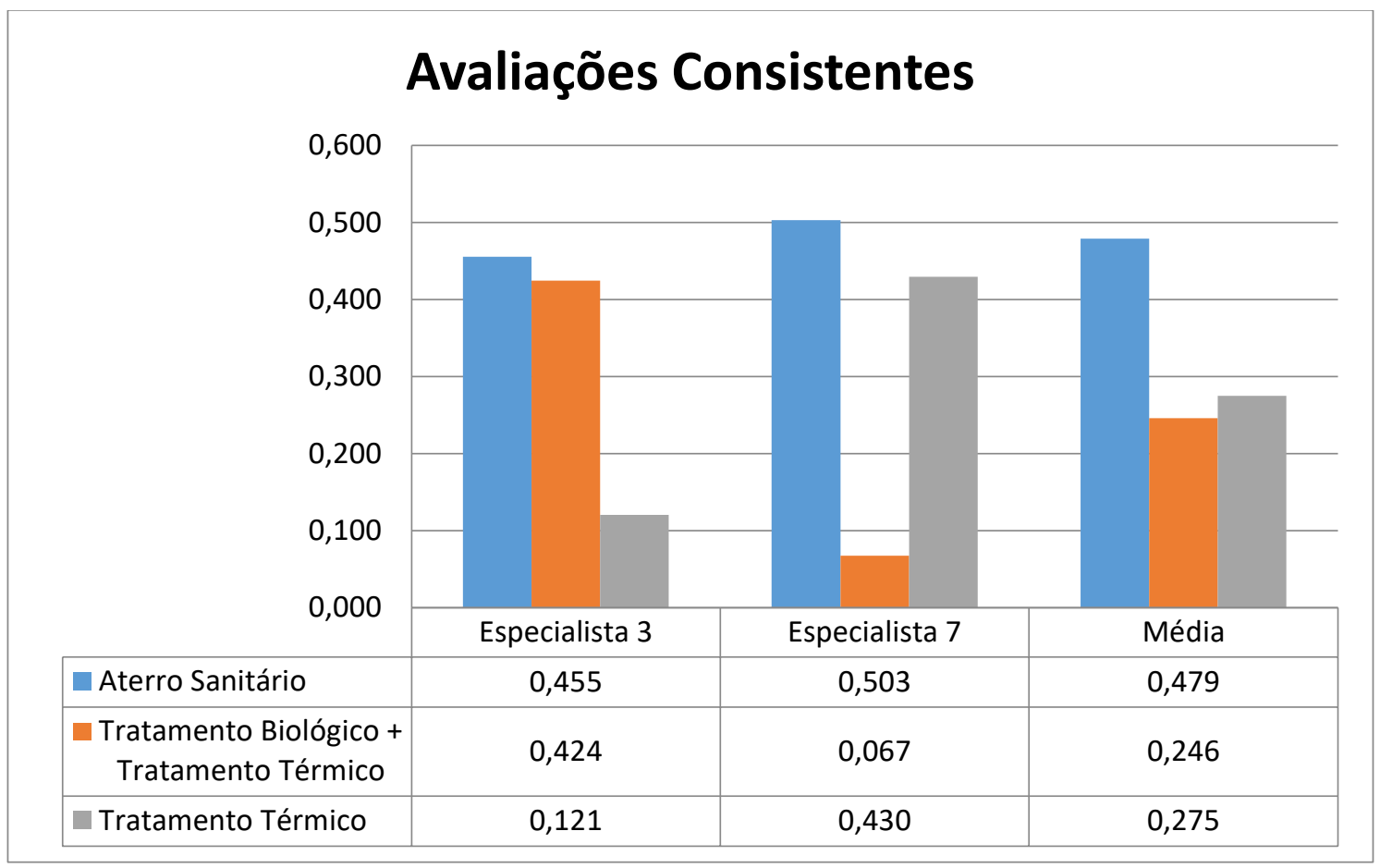

Gráfico 2 - Avaliações validadas pela metodologia. 
O gráfico 1, apresenta os resultados das avaliações dos colaboradores, sem excluir as avaliações inconsistentes. Assim, chegou-se aos resultados médios quanto ao custo geral (custo de logística, custo de implantação da tecnologia e custos socioambientais) praticamente idêntico entre o Aterro Sanitário $(35,2 \%)$, Tratamento Biológico associado ao Tratamento térmico $(31,1 \%)$ e Tratamento Térmico sem a segregação de RSU $(33,7 \%)$. Ou seja, de acordo com as avaliações dos especialistas, em termos de custo geral, todas as alternativas apresentadas tem igual relevância.

Ao passo que, quando consideradas apenas as avaliações consistentes, conforme disposto nos gráfico 2, o Aterro Sanitário apresenta maior custo geral (47,9\%). O Tratamento Biológico associado ao Tratamento Térmico de RSU $(24,6 \%)$ e Tratamento Térmico sem segregação de RSU (27,5\%) apresentam custos praticamente iguais.

Faz-se mister ressaltar que para efeito desta metodologia, a inconsistência é calculada através de testes matemáticos. Contudo, as avaliações, mesmo que inconsistentes devem ser analisadas. Não para serem incluídas nesta metodologia, mas para fornecerem uma visão holística dos elementos envolvidos na decisão.

Isto se justifica devido a sensibilidade, percepção, experiência dos colaboradores que, apesar de seus formulários porventura apresentarem dados inconsistentes, estão carregados de toda a expertise de cada um deles. Testes matemáticos embora precisos, não são capazes de contemplar toda sensibilidade e percepção humanas. E como toda ferramenta, sua existência se justifica a fim de auxiliar em uma determinada atividade.

Como neste estudo foram atribuídas às importâncias de cada critério pesos iguais, os resultados praticamente não sugerem uma via tecnológica mais adequada ao Tratamento de RSU. Visando extrair da metodologia um maior aproveitamento da experiência dos colaboradores, optou-se por avaliar cenários onde ora a importância dos custos de implantação fosse expressivamente 
superior (peso 7, conforme tabela 8), ora assim fosse a importância dos custos socioambientais. No primeiro cenário, foram atribuídas relevâncias mais significativas para os Custos de Implantação (importância a luz do foco principal, com peso 7 para este critério) dos empreendimentos necessários ao tratamento de RSU; no segundo cenário, atribuiu-se uma relevância maior para os Custos dos Impactos Socioambientais (importância a luz do foco principal).

Desta maneira, tem-se o resultado conforme o gráfico 3 apresenta:

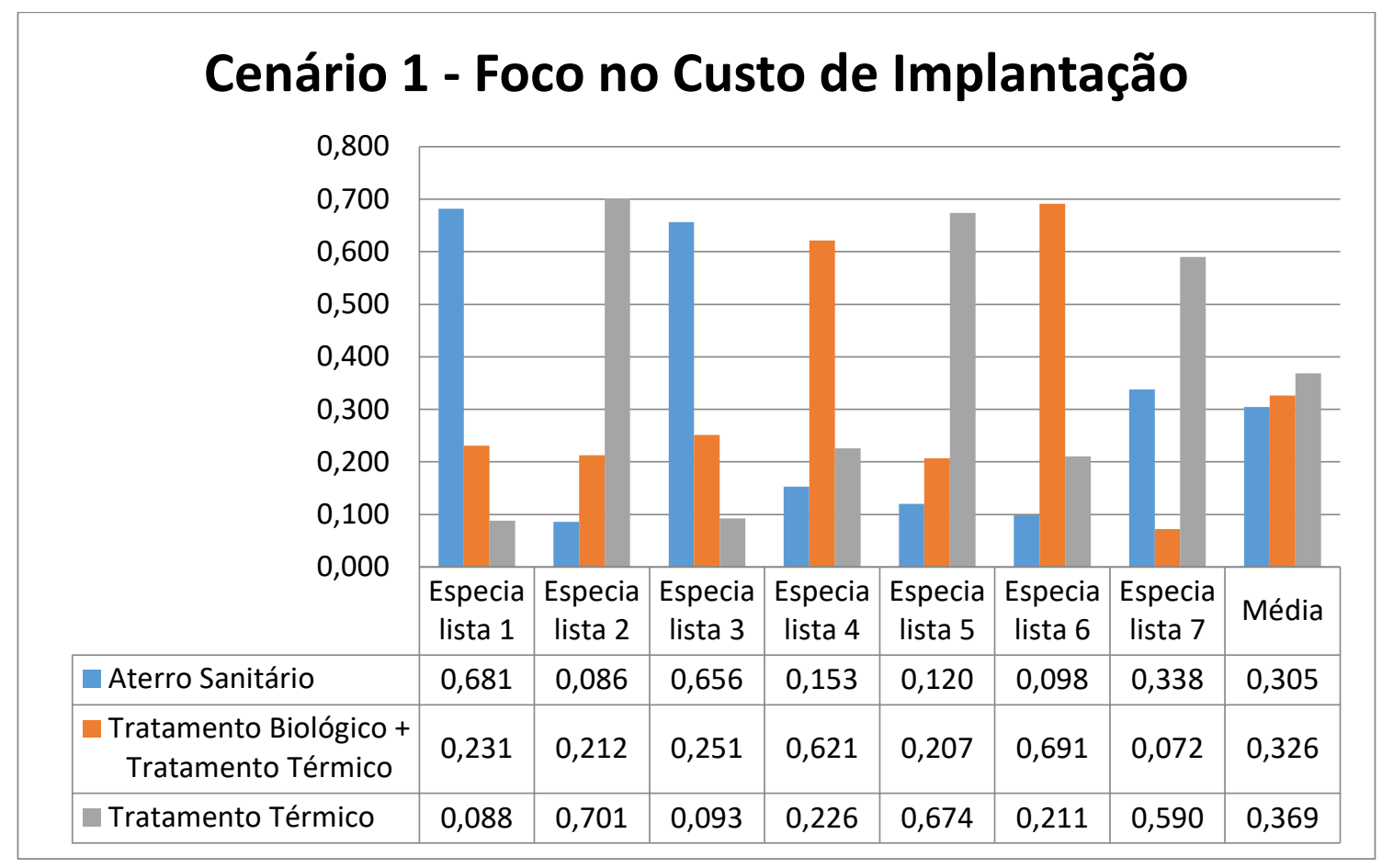

Gráfico 3 - Cenário 1 - considerado o custo mais elevado para a implantação dos empreendimentos para tratamento de RSU.

Novamente, ao se observar os resultados consolidados (gráfico 3), considerando todas as avaliações e tendo o custo da implantação dos empreendimentos envolvidos para o tratamento dos RSU como expressivamente mais relevante, os resultados apontam de modo semelhante todas as possibilidades consideradas com praticamente o mesmo resultado, sendo o Aterro Sanitário $30,5 \%$ mais adequado (menor custo), o Tratamento Biológico associado ao Tratamento Térmico 32,6\% e o Tratamento Térmico sem segregação de RSU com $36,9 \%$ (maior custo). 


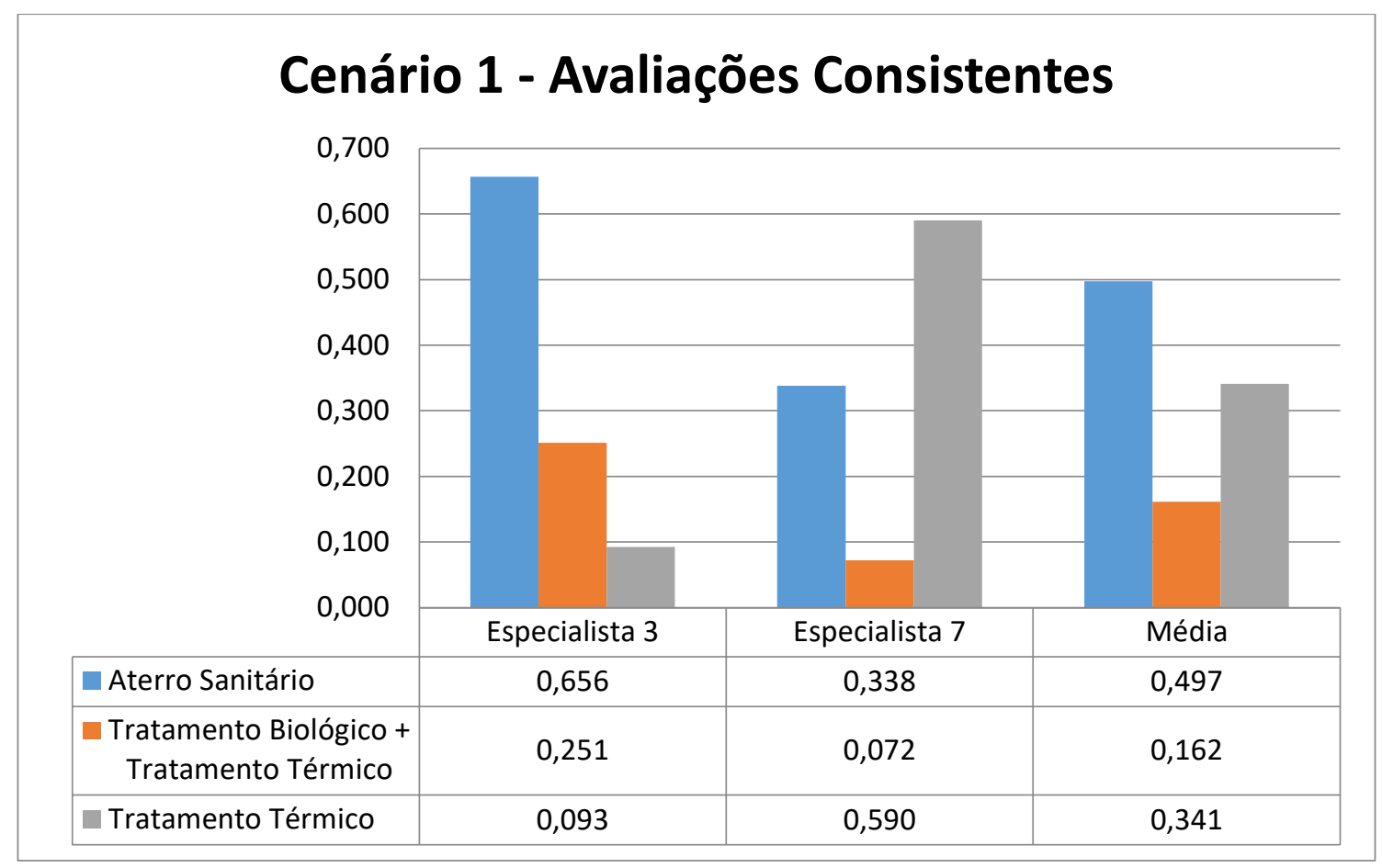

Gráfico 4 - Validação do cenário 1 pela metodologia AHP.

A partir da leitura do gráfico 4, considerando apenas as avaliações consistentes, obteve-se como resultado de menor custo geral (considerando o custo de implantação expressivamente superior aos custos socioambientais) o Tratamento Biológico associado ao Tratamento Térmico com 16,2\%. Sendo o Tratamento Térmico sem segregação de RSU com 34,1\% e o Aterro sanitário com $49,7 \%$ as alternativas de custo geral maior.

Para o segundo cenário, foi realizado um ensaio dentro desta metodologia, com uma maior valorização dos impactos socioambientais em relação aos custos implantação e operação dos empreendimentos de tratamento de RSU. Assim, ao atribuir-se um peso maior a este critério (peso 7), construiu-se o gráfico 5 . 


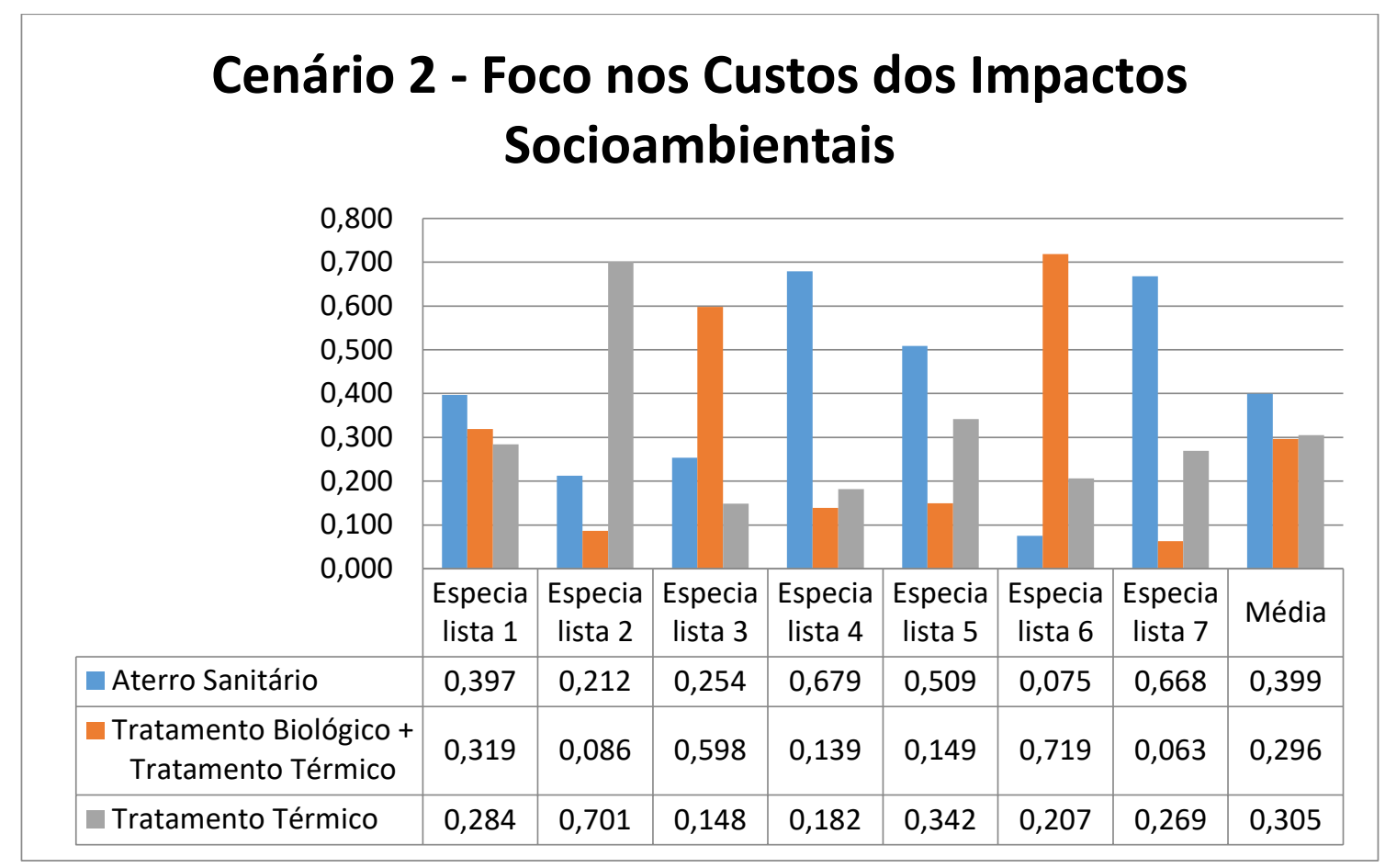

Gráfico 5 - Cenário 2 com todas as avaliações.

O gráfico 5 apresenta o cenário 2 cuja importância dos custos socioambientais foi compreendida como expressivamente superior (peso 7) aos custos de implantação. Desta forma, segundo estas condições, as avaliações dos especialistas apontam como o Tratamento Biológico associado ao Tratamento térmico como forma mais adequada com $29,6 \%$ de custo geral, acompanhado do Tratamento Térmico sem segregação de RSU com $30,5 \%$ dos custos gerais e por fim o Aterro Sanitário com $39,9 \%$.

Assumindo esta realidade, o gráfico 5 apresenta valores praticamente idênticos para o Tratamento Biológico associado com Tratamento Térmico e o tratamento Térmico indiferenciado dos RSU.

Contudo, como a metodologia exige que as inconsistências sejam testadas, o gráfico 6 trabalha apenas com as avaliações consideradas consistentes. 


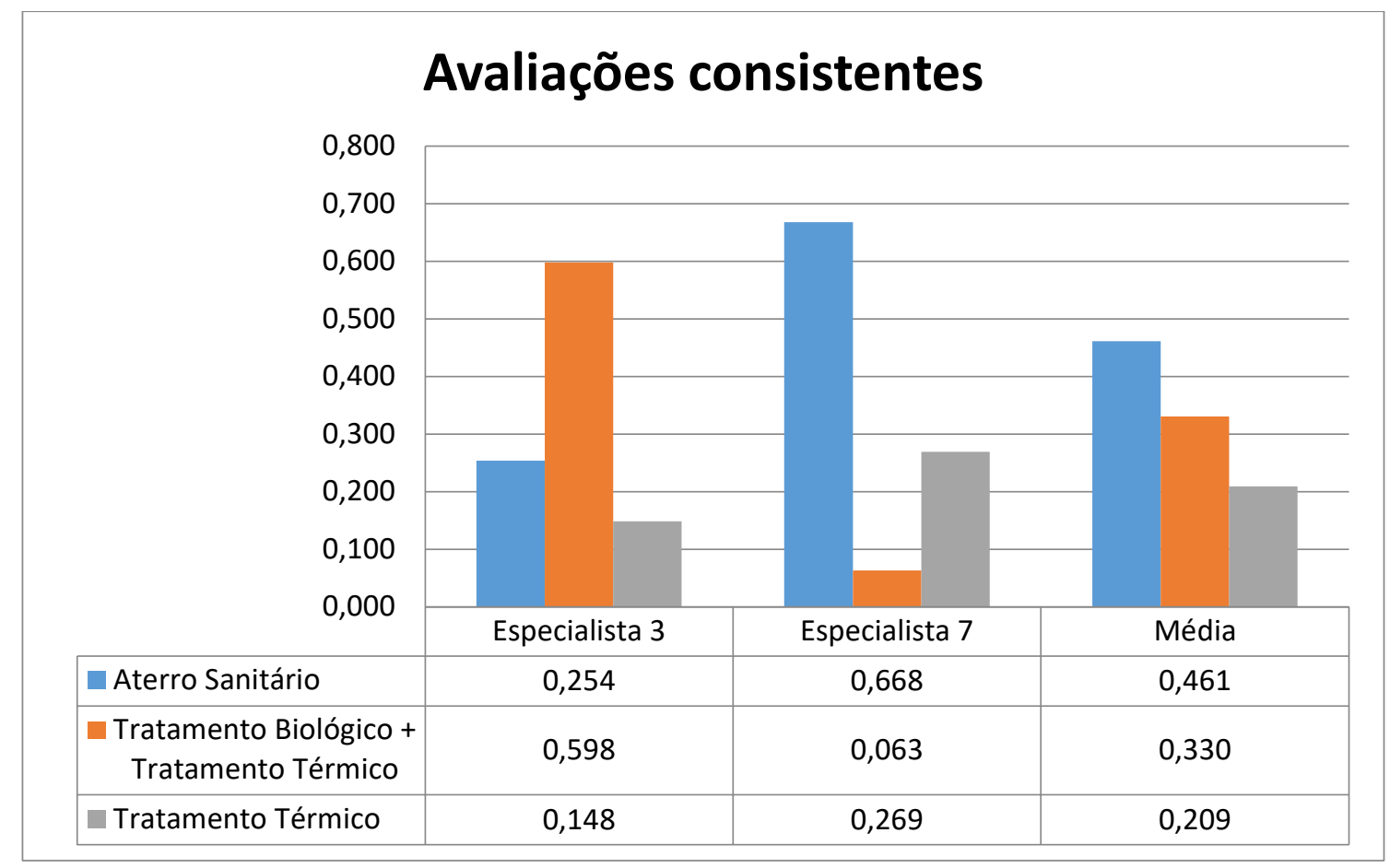

Gráfico 6 - Resultados a partir dos formulários consistentes para o cenário 2.

Nesta situação, após a consolidação dos dados, a metodologia aponta como solução mais viável O Tratamento Térmico sem segregação dos RSU com o custo geral de 20,9\%; e em segundo lugar, o Tratamento biológico associado ao Tratamento Térmico com 33\% ao considerar o custo geral. A alternativa com custos gerais maiores, segundo os colaboradores, dentro desta realidade cujos impactos socioambientais pesem mais que os custos de implantação, aparece o Aterro sanitário com 46,1\%.

De forma geral, utilizando-se das avaliações e nas 3 realidades, pode-se observar que as 3 alternativas são praticamente idênticas em se tratando de custos de implantação e custos socioambientais.

Paralelamente a aplicação da análise AHP, foi solicitado a cada especialista que atribuísse uma nota numa escala de 1 a 10, onde a nota 1 significaria um custo elevadíssimo e 10 um custo baixíssimo. Sendo os critérios inquiridos os custos de Coleta, onde as possibilidades avaliadas são o custo da Coleta COM segregação dos RSU e o custo da Coleta SEM a segregação dos RSU; os custos de Implantação da tecnologia, onde se avaliou o custo individual do 
aterro sanitário, do incinerador e do biodigestor anaeróbio. E por fim o custo dos impactos socioambientais para as mesmas variáveis anteriores.

Como os valores são inversamente proporcionais, valores maiores apresentam custos menores. A partir dos formulários preenchidos pelos especialistas colaboradores (Apêndice II) construiu-se o gráfico 7 .

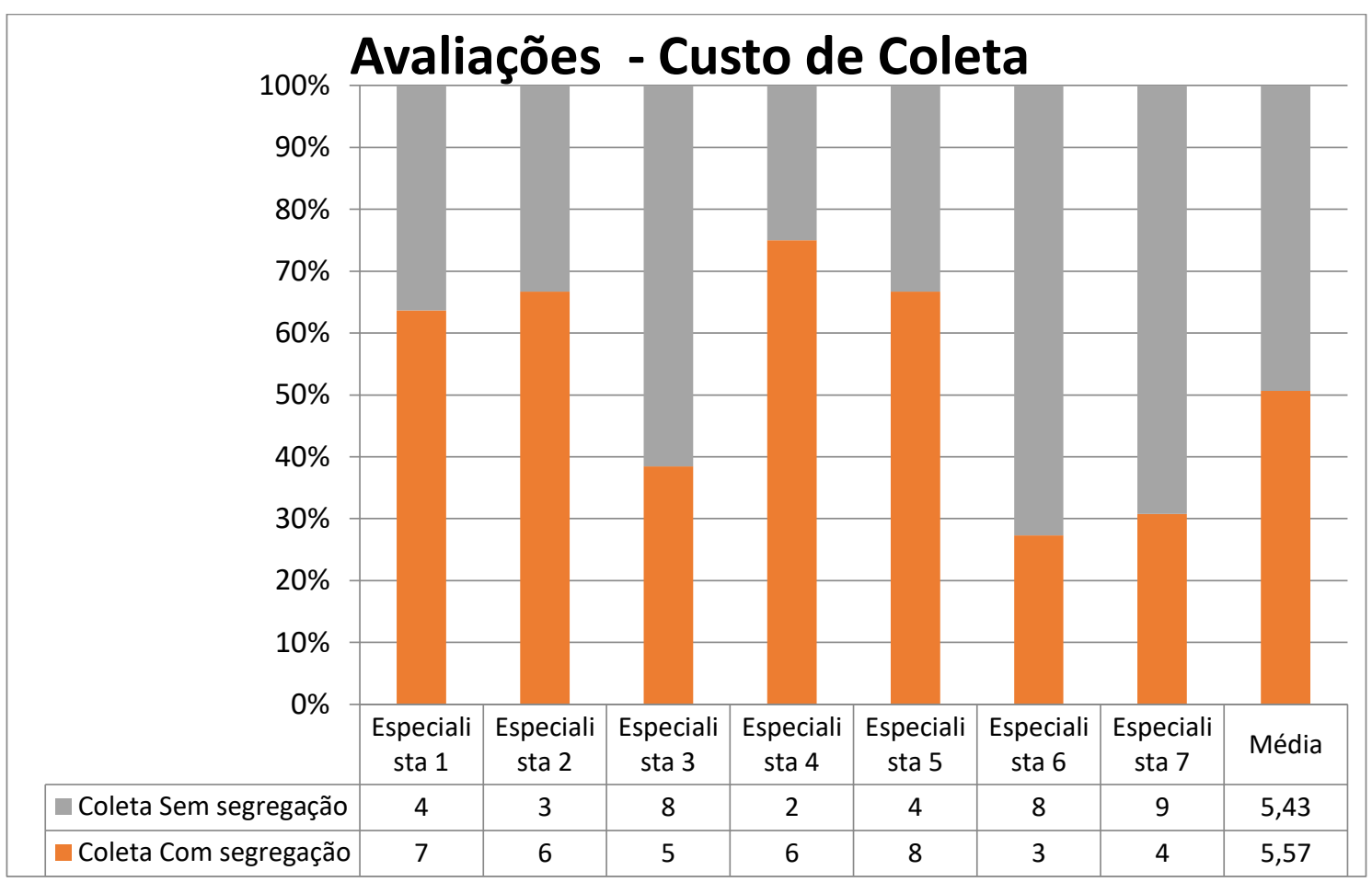

Gráfico 7 - Custo de Logística a partir das notas dos especialistas.

No gráfico 7 , ao se observar os valores médios para os custos da Coleta de RSU sem segregação e para os custos da Coleta com segregação de RSU, tem-se 5,43 pontos para a primeira condição e 5,57 pontos para a segunda opção. Os valores médios apontam para custos praticamente iguais.

O segundo critério avaliado foi o Custo da Implantação das Tecnologias, especificamente para Aterro Sanitário, Incinerador e Biodigestor Anaeróbio. Cabe ressaltar que nesta avaliação, apenas a incineração foi considerada, devido o fato desta tecnologia poder tratar os RSU com ou sem segregação, conforme descrito por Feam (2010). O biodigestor foi escolhido pelo fato de ser 
indicado para grandes volumes de RSU, conforme afirmam Li, Park e Zhu (2011), Scano et al. (2014), Jin et al. (2015).

Assim, seguindo o mesmo critério de pontuação, as avaliações dos especialistas foram consolidadas e podem ser vistas no gráfico 8 .

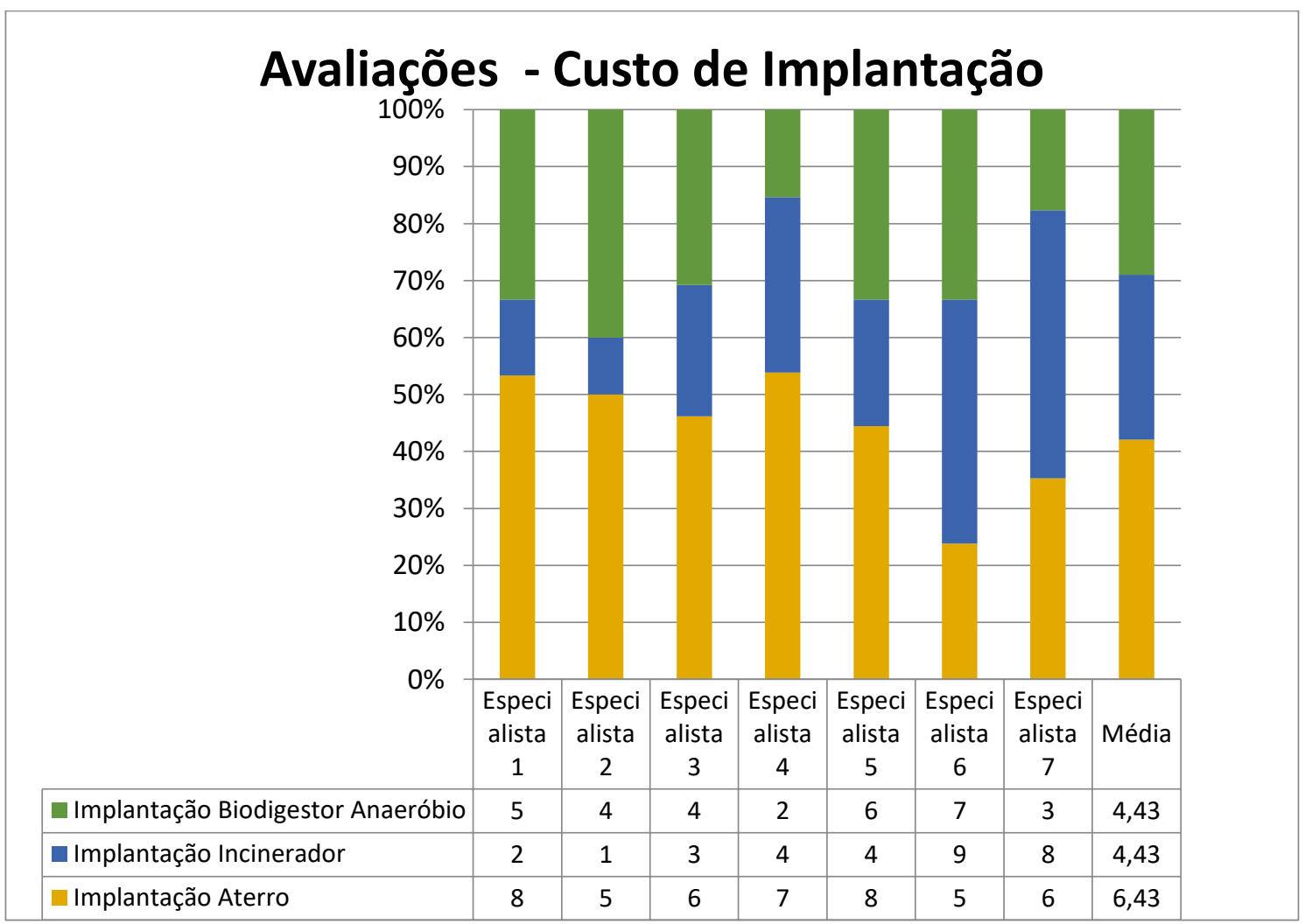

Gráfico 8 - Custo de Implantação de tecnologias de tratamento a partir das avaliações dos especialistas.

No gráfico 8 , segundo as avaliações dos colaboradores, os custos de implantação do incinerador e do biodigestor anaeróbio são iguais, com 4,43 pontos cada. E o custo de implantação do aterro sanitário atingiu 6,43 pontos, resultando em 2 pontos a mais que a média das alternativas. Cabe ressaltar que valores mais baixos representam custos maiores. Seguindo essa lógica, o aterro sanitário possui custo menor para a sua implantação. 
Por fim, tem-se o gráfico 9 que apresenta valores consolidados a partir das avaliações dos especialistas colaboradores para os Custos dos Impactos Socioambientais.

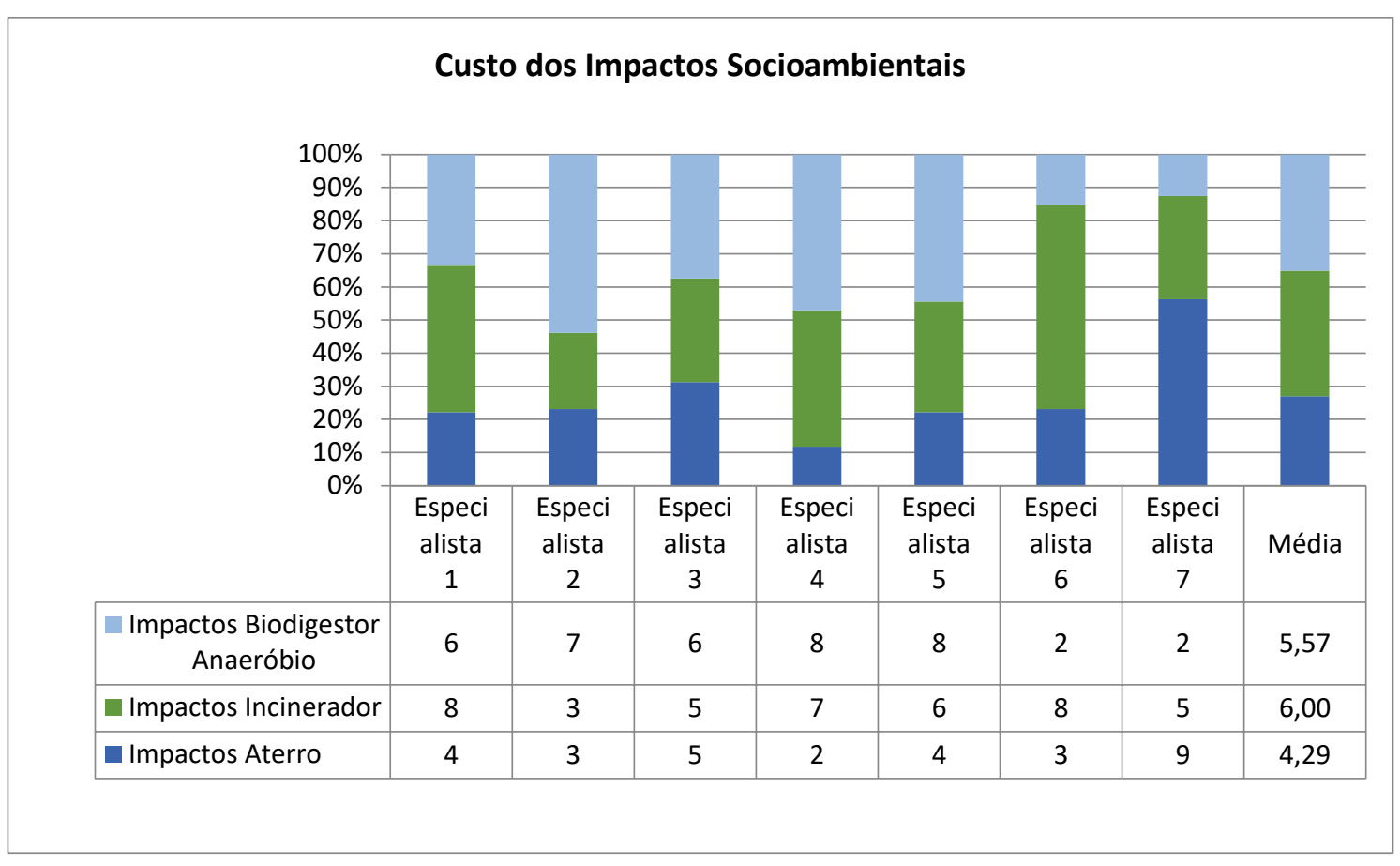

Gráfico 9 - Custo dos Impactos socioambientais a partir das notas dos especialistas.

O gráfico 9 apresenta média de 6 pontos para os custos dos impactos socioambientais da utilização de incineradores para tratamento de RSU, 5,57 pontos para os impactos do biodigestor anaeróbio e 4,29 pontos para os custos de impactos socioambientais causados pelos aterros sanitários.

Numa comparação entre as avaliações realizadas por cada colaborador, pode-se consolidar a tabela 18, onde alguns colaboradores apresentam posicionamentos contraditórios quanto a critérios iguais. 


\begin{tabular}{|c|c|c|c|c|}
\hline & \multicolumn{2}{|c|}{ AHP } & \multicolumn{2}{|c|}{ Notas } \\
\hline & $\begin{array}{l}\text { Coleta de resíduos sem } \\
\text { segregação (coleta de } \\
\text { resíduos indiferenciados) }\end{array}$ & $\begin{array}{l}\text { Coleta de resíduos com } \\
\text { segregação (coleta de } \\
\text { resíduos diferenciados) }\end{array}$ & $\begin{array}{l}\text { Coleta de resíduos } \\
\text { sem segregação } \\
\text { (coleta de resíduos } \\
\text { indiferenciados) }\end{array}$ & $\begin{array}{l}\text { Coleta de resíduos } \\
\text { com segregação } \\
\text { (coleta de resíduos } \\
\text { diferenciados) }\end{array}$ \\
\hline 1 & 5 & & 7 & 4 \\
\hline 2 & & 5 & 6 & 3 \\
\hline 3 & 7 & & 5 & 8 \\
\hline 4 & & 7 & 6 & 2 \\
\hline 5 & & 7 & 8 & 4 \\
\hline 6 & & 9 & 3 & 8 \\
\hline \multirow[t]{2}{*}{7} & & 7 & 4 & 9 \\
\hline & \multicolumn{2}{|c|}{ Maior valor = maior custo } & \multicolumn{2}{|c|}{ Maior valor $=$ menor custo } \\
\hline Especialista 1 & \multirow{2}{*}{\multicolumn{4}{|c|}{ Pela analise AHP, o custo de coleta sem segregação de RSU é alto. Pela avaliação direta avalia o oposto. }} \\
\hline \multicolumn{2}{|l|}{ Especialista 2} & & & \\
\hline \multicolumn{5}{|l|}{ Especialista 3} \\
\hline \multicolumn{5}{|l|}{ Especialista 4} \\
\hline \multicolumn{5}{|l|}{ Especialista 5} \\
\hline Especialista 6 & \multicolumn{4}{|c|}{ Pela analise AHP, o custo de coleta sem segregação de RSU é alto. Pela avaliação direta avalia o oposto. } \\
\hline Especialista 7 & \multicolumn{4}{|c|}{ Pela analise AHP, o custo de coleta sem segregação de RSU é alto. Pela avaliação direta avalia o oposto. } \\
\hline
\end{tabular}

Tabela 18 - Comparativo consolidado a partir da avaliação pela metodologia AHP e avaliação direta, por cada colaborador.

\subsubsection{Consolidação das avaliações}

A análise AHP é pautada pela seleção de alternativas variadas dispostas em níveis hierárquicos, que são julgadas conforme comparações realizadas sempre aos pares, e dispostas sob critérios previamente estabelecidos. Tais condições são dispostas em matrizes que permitem ao tomador de decisão (usuário da metodologia) escolher a melhor opção.

Neste trabalho, foram consultados 7 colaboradores especialistas na área de Resíduos Sólidos, os quais contribuíram para que fosse escolhida a melhor forma de tratar resíduos sólidos urbanos (um tratamento ou combinação de tecnologias).

Os avaliadores foram consultados sem que o pesquisador soubesse suas respectivas formações e identidades.

Os colaboradores foram consultados através de formulários (anexo II) que segundo a metodologia, foram apresentadas combinações de tecnologias de tratamento de resíduos sólidos, de modo que fossem comparadas 3 situa- 
ções possíveis: atual de disposição final (Aterro Sanitário), Tratamento biológico combinado com tratamento térmico (com segregação de RSU) e Tratamento Térmico (sem segregação de RSU). Quanto aos critérios considerados, o Custo de Logística (que consistia na percepção de custos envolvidos na coleta, segregação e destinação final dos RSU), Custos Internos (que consistia na percepção dos custos envolvidos no negócio, desde a sua construção, quanto a operação, manutenção, troca de equipamentos e insumos necessário ao funcionamento do negócio) e Custos externos (que consistia nos custos relativos aos impactos ambientais, sociais, ações preventivas e mitigadoras necessárias a operação e descomissionamento ao fim do negócio).

Além desta avaliação, foi solicitado a cada colaborador que fizesse uma avaliação direta para o Custo de Coleta de RSU sem segregação e com segregação; Custo Interno de Aterro Sanitário, de Incinerador e de Biodigestor Anaeróbio; além do Custo Externo de Aterro Sanitário, de Incinerador e de Biodigestor Anaeróbio.

O objetivo desta segunda avaliação foi permitir uma comparação entre a metodologia e a percepção de cada colaborador. Como a metodologia da avaliação AHP está associada a consistência logica na avaliação, a percepção dos colaboradores poderia ser utilizada a fim de observar a aderência de suas experiências tanto a metodologia quanto a avaliação das opções apresentadas.

Das 7 avaliações, após a avaliação de consistência, apenas 2 foram consideradas conforme a metodologia AHP exige (teste de consistência). Os especialistas de numero 3 e de numero 7 .

Ao se observar os resultados válidos, segundo a metodologia AHP sugere, a opção que apresentou maiores custos foi o Aterro Sanitário, que é a resposta atual como disposição final dos RSU. As alternativas apresentadas como soluções para o tratamentos destes RSU aparecem praticamente empatadas, sendo a solução combinada de tratamento biológico com tratamento térmico com $24,6 \%$ e o tratamento térmico sem segregação de resíduos com $27,5 \%$. 
Todavia, para efeito de comparação das avaliações segundo a metodologia AHP e as avaliações diretas, as avaliações consideradas inconsistentes (resultados dos avaliadores 1, 2, 4, 5 e 6) foram apresentadas no gráfico 1.

Pode-se observar neste gráfico que não houve consenso entre os avaliadores, pois os resultados apontavam para um empate entre todas as opções, se fossem consideradas pela metodologia.

Como a segregação de resíduos é determinante para que uma das alternativas seja adotada (tratamento biológico associado ao tratamento térmico), considerou-se o Custo de Logística como inerente às alternativas. Assim, a análise AHP prosseguiu com os critérios de Custos Internos e Externos.

Neste contexto, para que os Custos Internos e Externos fossem avaliados numa perspectiva não tendenciosa, atribuiu-se o mesmo peso para ambos os critérios. Cabe ressaltar que neste contexto, custos gerais menores representam impactos menores.

Após a avaliação, foi realizada uma simulação a partir dos dados obtidos buscando perceber quais resultados poderiam ser observados se variassem os pesos dos critérios adotados. Os critérios adotados neste trabalho, como já mencionado, foram os custos de logística, Custos Internos e Custos Externos.

Num primeiro cenário, os custos Internos receberam um peso maior (peso 7 - o segundo maior valor segundo a tabela apresentada pelo autor da metodologia). Neste cenário, a opção de menor custo foi a combinação de tratamento biológico com tratamento térmico (incluindo os custos de segregação de RSU) com 16,2\%; o Tratamento Térmico sem segregação de RSU apresentou $34,1 \%$ e o Aterro Sanitário com 49,7\% (gráfico 4) quando consideradas as avaliações válidas pela metodologia AHP. Embora, se observadas as avaliações inconsistentes e consistentes, os resultados apontam para resultados empatados, ou melhor, dizendo, inconclusivos por não apresentar nenhum resultado preferencial. 
No segundo cenário, foi adotado o mesmo peso para o critério de Custos Externos (peso 7). Então, os resultados considerados válidos nesta metodologia apontaram para o Tratamento Térmico sem segregação de RSU. Em segundo lugar, a solução associada de Tratamento Biológico com Tratamento Térmico (com segregação de RSU) e por fim o Aterro Sanitário. Quando observados todos os resultados, houve uma preferencia para a opção de Tratamento Biológico associado ao Tratamento Térmico (com segregação de RSU) com 29,6\% dos custos gerais, seguida de Tratamento Térmico sem segregação de RSU com 30,5\% dos custos gerais e o Aterro Sanitário com 39,9\% dos custos gerais.

Paralelamente a isso, observou-se os resultados das avaliações diretas dos colaboradores e como média de suas avaliações, obteve-se 5,43 para coleta sem segregação e 5,57 para coleta com segregação de resíduos (gráfico 7).

Contudo, ao analisar-se as avaliações, observou-se os colaboradores especialistas de numero 1, 2,4 e 5 atribuíram uma importância acima dos valores médios apresentados para a coleta de RSU com Segregação, já os colaboradores de numero 3, 6 e 7, consideraram mais importante a coleta sem segregação de RSU. O que explica os valores médios são os valores individuais atribuídos por cada colaborador.

Quando analisado o critério do Custo Interno, as médias alcançadas pelas avaliações dos colaboradores foram de 6,43 pontos para o Aterro Sanitário e de exatos 4,43 pontos para as demais alternativas (tratamento Biológico associado ao Tratamento Térmico - uso de Biodigestores Anaeróbios e Tratamento Térmico sem segregação de RSU - uso de Incineradores), sugerindo que a opção preferencial para os RSU seja o Aterro sanitário (gráfico 8).

Pontualmente, cada colaborador teve uma preferencia dentre as opções. Pode-se agrupar os colaboradores conforme suas preferencias considerando $o$ custo Interno acima da média geral, da seguinte forma: 
- Biodigestor Anaeróbio - colaborador especialista 6;

- Incinerador - colaboradores especialistas 6 e 7;

- Aterro Sanitário - colaboradores especialistas 1, 3, 4 e 5.

O colaborador especialista de numero 1 o uso de aterros sanitários o mais indicado para a disposição final de RSU (8 pontos). O uso de biodigestor anaeróbio levemente superior a media (5 pontos para uma média de 4,43 ).

O colaborador de numero 2 ao avaliar as alternativas atribuiu importâncias inferiores a ambas as medias (biodigestor anaeróbio com 4 pontos numa média de 4,43; incinerador como a alternativa de menor importância com 1 ponto para uma média de 4,43; e o uso de aterros sanitários com 5 pontos para uma média de 6,43). Cabe ressaltar que dentre suas avaliações, optou como solução mais indicada o uso de aterros sanitários.

O colaborador de numero 3 de modo semelhante ao colaborador anterior, também avaliou as alternativas com valores abaixo de suas respectivas médias, com o destaque para o aterro sanitário como opção mais indicada.

O colaborador de numero 4 atribuiu o uso de aterros sanitários como alternativa preferencial (7 pontos), com as demais alternativas com valores abaixo de suas respectivas médias.

O colaborador de numero 5 considerou o uso de aterros sanitários preferencial (8 pontos) para a disposição final dos RSU. Ainda considerou o uso de biodigestores anaeróbios ( 6 pontos) superior ao uso de incineradores (4 pontos).

O colaborador especialista de numero 6 atribuiu valores preferencias para o biodigestor anaeróbio ( avaliou com 7 pontos de importância numa escala de 10) e para o incinerador uma importância ainda maior ( avaliou com 9 pontos de importância numa escala de 10). 
O colaborador de numero 7 considerou a alternativa mais indicada o uso de incinerador (8 pontos). Para o uso de aterros sanitários, o mesmo colaborador atribuiu uma importância levemente inferior a média (6 pontos) e como alternativa menos indicada o uso de biodigestores anaeróbios (3 pontos).

Ainda segundo esta avaliação direta, para os Custos Externos, a media das avaliações apontou para o uso de incineradores com 6 pontos preferenciais, acompanhada de 5,57 pontos preferenciais para 0 uso de biodigestores anaeróbios e 4,29 pontos preferenciais para o uso de aterros sanitários (gráfico 9).

De modo similar, pode-se agrupar pontualmente, conforma a avaliação individual de cada colaborador conforme suas preferencias segundo o critério de custos externos acima da média geral, da seguinte forma:

- Biodigestor Anaeróbio - colaboradores especialistas 1, 2, 3, 4 e 5;

- Incinerador - colaboradores especialistas 1, 4, 5 e 6;

- Aterro Sanitário - colaboradores especialistas 3 e 7.

O colaborador especialista de numero 1 considerou o uso de incinerador para tratar os RSU preferencial (8 pontos numa escala de 10), seguido pelo uso de biodigestores anaeróbios ( 6 pontos na mesma escala). $O$ uso de aterros sanitários foi considerado por este colaborador como levemente inferior a media (4 pontos para uma média de 4,29).

O colaborador de numero 2 considera o uso de biodigestores anaeróbios preferencial ( 7 pontos) às demais alternativas ( 3 pontos cada).

O colaborador de numero 3 considera o uso do biodigestor anaeróbio levemente ( 6 pontos) superior às demais alternativas ( 5 pontos cada).

O colaborador de numero 4 considera o uso de biodigestores anaeróbios (8 pontos) e incineradores (7 pontos) muito mais indicados ao uso de aterros sanitários (2 pontos). 
O colaborador de numero 5 considera o uso de biodigestores anaeróbios preferenciais ( 8 pontos) em relação ao incinerador (6 pontos, que neste caso é o valor médio das avaliações) e o uso de aterros sanitários (4 pontos).

O colaborador de numero 6 considerou o uso de incinerador (8 pontos) o mais indicado para tratamento de RSU. Para o uso de Aterros sanitários, considerou como quase tão impactante ao ambiente e a sociedade (3 pontos) quanto ao uso de biodigestores anaeróbios (2 pontos).

O colaborador de número 7 considerou o uso de aterros sanitário o mais indicado (9 pontos) para a disposição final dos RSU. O mesmo avaliador atribuiu uma avaliação inferior a média para o uso de incineradores ( 5 pontos para uma média de 6) e considerou como a alternativa mais impactante ao ambiente e a sociedade o uso de biodigestores anaeróbios (2 pontos).

Ao realizar-se o cruzamento das informações, conforme descrito na tabela 18, pode-se destacar algumas avaliações contraditórias. De acordo com os formulários (anexo II), para a análise AHP, as avaliações comparavam os custos de modo paritário. Assim, custos menores seriam preferenciais. Já para as avaliações diretas, valores mais altos seriam preferencias.

Desta forma, os colaboradores especialistas de numero 1, 6 e 7, através da analise AHP avaliam que o custo da coleta sem segregação de RSU é alto, ao passo que nas respectivas avaliações diretas, avaliam este custo como inferior ao custo de coleta com segregação.

Observando ainda as avaliações de cada colaborador, retornando ao gráfico 1, nota-se que ao final da analise AHP as avaliações se mostram contraditórias. Isso fica evidenciado quando se analisa caso a caso os resultados obtidos por cada colaborador.

O colaborador de numero 1 avaliou como solução de menos custo geral o tratamento térmico sem segregação de RSU $(18,6 \%)$, seguida por tratamento 
biológico associado com tratamento térmico $(27,5)$ e o aterro sanitário como solução de maior gasto total $(53,9 \%)$.

O colaborador de numero 2 avalia aterro sanitário e tratamento biológico associado com tratamento térmico como soluções preferenciais com igual intensidade (14,9\% para ambas as alternativas) em relação ao tratamento térmico sem segregação de RSU (70,1\%), o qual teria custos gerais maiores.

O colaborador de numero 3 considera o tratamento térmico indiferenciado dos RSU (12,1\%) como solução preferencial, ao passo que tratamento biológico associado ao tratamento térmico e aterro sanitário aparecem praticamente empatado ( $42,4 \%$ e $45,5 \%$ respectivamente) como soluções com maiores custos gerais.

O colaborador de numero 4 avalia o tratamento térmico sem segregação de RSU como solução mais viável, isto é, com menores custos gerais (20,4\%) segundo sua avaliação. Com tratamento biológico associado ao tratamento térmico em segundo (38\%) e aterro sanitário como solução mais onerosa $(41,6 \%)$.

O colaborador de numero 5 avalia o tratamento biológico associado ao tratamento térmico como solução mais viável (17,8\%). Sendo o que considera o uso de aterro sanitário como segunda solução mais viável $(31,4 \%)$ em relação ao tratamento térmico sem segregação de RSU $(50,8 \%)$.

O colaborador de numero 6 avalia o uso de aterros sanitários como solução mais viável $(8,7 \%)$. Ainda considera o tratamento térmico sem segregação de RSU $(20,9 \%)$ como alternativa quando comparados ao tratamento biológico associado ao tratamento térmico (70,5\% dos custos gerais).

O colaborador de numero 7 contrasta com o colaborador anterior por avaliar o tratamento biológico associado ao tratamento térmico como solução preferencial $(6,7 \%)$, quando comparado com o tratamento térmico sem segregação de RSU (43\%) e aterros sanitários (50,3\%). 
Como a análise AHP avalia a consistência das avaliações, neste contexto a metodologia considerou apenas os colaboradores de numero 3 e 7 . Os resultados do primeiro colaborador apontam o tratamento térmico sem segregação de RSU como solução mais viável quando comparado com as demais alternativas (aterro sanitário e tratamento biológico associado com tratamento térmico). Já o segundo colaborador aponta para tratamento biológico associado ao tratamento térmico como solução de menor custo geral. Em relação ao uso de aterro e tratamento térmico sem segregação de RSU com pequenas diferenças como soluções. 


\subsection{DISCUSSÃO}

A metodologia de análise multicritério AHP, estabelece prioridades. Tais prioridades são definidas a partir da sensibilidade do seu usuário e após a estruturação da hierarquias, e das comparações paritárias, ocorre o o julgamento que tornam a escolha (primeiro nível da hierarquia) (SAATY, 1977). Cabe ao usuário estruturar de forma adequada esta hierarquia para que o processo seja utilizado corretamente (Costa, 2002; Paiva e Bueno, SD).

Pereira e Bianchini (2013) atribuem à análise AHP a capacidade de identificar a melhor opção dentre uma variedade e ranquear as mesmas alternativas segundo critérios pré-definidos. Ainda citam as possibilidades de utilizar valores qualitativos (pesos atribuídos) e quantitativos (notas a partir das comparações); pode ser adotado em grupos decisórios ou individualmente; além da facilidade de referencias na literatura e de poder contar com um olhar subjetivo a partir das avaliações.

Contudo, esta identificação da melhor opção dentre varias, está associada a critérios subjetivos Schmidt e Barbosa (2016), fato que pode ser combatido com a participação de opiniões de colaboradores (Grandazol; 2005). Tal subjetividade é inerente à condição humana, e deve ser considerada (SAATY, 2008). E a metodologia não só as considera como também é capaz de avalialas através do teste de consistência.

Como a ferramenta AHP é uma ferramenta gerencial, está sujeita à lógica técnico-econômico, pois se baseia na consulta de especialistas para julgarem alternativas conforme seus respectivos conhecimentos, a fim de auxiliar aos tomadores de decisão quanto a melhor escolha dentro de uma dada realidade. 
É preciso se questionar se uma ferramenta de apoio a decisão, onde apenas alguns interessados, que seguem tal logica tecnocrática, de forma que as decisões seguem de modo vertical serve para auxiliar a tomada de decisão onde há varias possibilidades em que pros e contras não apresentam superioridade aparente e exigem uma consulta mais apurada, ou justificar uma decisão já tomada de forma a convencer aos demais atores que tem menor peso político-econômico.

Somando-se a isso, pode-se considerar esta ferramenta como reducionista, pois ao se relacionar valores às possibilidades, aos cenários considerados, muitas informações podem ser descartadas. Tal situação pode negligenciar muitas variáveis. Desta forma, ao se considerar a aplicação desta ferramenta para resolver situações complexas como o tratamento de resíduos sólidos urbanos, pode-se questionar se o resultado é o mais adequado, ou se o resultado da alcançado condiz com a realidade.

Pode-se compreender o resultado de reducionismo como aproximações. Tais aproxi-mações acabam por descartar informações que podem ser relevantes num contexto maior, impactando no processo decisório. Wynne (1992) ressalta tal condição quando avalia questões ambientais, onde a complexidade de fatores envolvidos geram variáveis muitas vezes incomensuráveis. O autor chama de incerteza quando as probabilidades de um evento ocorrer são desconhecidas. Assim, o autor defende que para questões de analises ambientais, por possuir uma maior complexidade, não são completamente contempladas pela abordagem metodológica cientifica tradicional e aponta para a abordagem cientifica pós-normal. Porto e Freitas (2003) defendem o uso de uma abordagem dentro da lógica da ciência pós-normal em ambientes em que as incertezas são relevantes em processos de to-mada de decisão.

Outra questão precisa ser considerada ao se analisar se apenas a visão gerencial pode ser considerada. A participação de todos os atores envolvidos pode trazer uma maior precisão quanto a escolha mais indicada (neste caso, a melhor combinação de tecnologias para o tratamento de resíduos sólidos urbanos). Autores como Funtowicz at Ravetz (1997), Porto e Freitas (2003) afir- 
mam que a ciência aplicada puramente não é capaz de resolver sistemas complexos como as consequências ambientais resultantes das atividades humanas. Assim, apontam formas de possibilitar escolhas mais precisas quanto às reais necessidades socioambientais. Os autores ainda ressaltam que a exclusão social nos processos de tomada de decisão é um fator determinante para a manutenção do atual modelo de resolução de conflitos ou de solução de problemas.

Funtowicz at Ravetz (1997) apontam a Ciência Pós-Normal como um conceito que aproxima avaliações, pois trabalha de modo aplicado com elementos interdisciplinares. Desta maneira, a participação de vários atores é considerada, onde vários olhares se complementam. A isso, os autores se referem como "comunidades ampliadas de pares". Jacobi (2000) reforça esta ideia ao constatar que os atores envolvidos nos processos de tomada de decisão (a população consultada na cidade de São Paulo) tem uma percepção real dos desdobramentos ambientais a partir do uso de tecnologia de incineração de resíduos sólidos urbanos.

Nota-se que em países em desenvolvimento, a logica técnico-econômica e político-econômica são dominantes face às necessidades socioambientais, como afirmam Porto e Freitas (2003). Dentro deste contexto, pode-se considerar que as vulnerabilidades estão concentradas nesta esfera, e os problemas se desdobram a partir da falta de investimentos em serviços urbanos, ações ambientais, saneamento ambiental, educação, entre outros.

Neste estudo, foram consultados 7 especialistas da área, cujas identidades não foram de conhecimento dos pesquisador com o objetivo de aplicar a metodologia sem qualquer influencia a partir da formação do colaborador. Num universo de 7 avaliações realizadas, apenas duas foram consideradas consistentes de acordo com a metodologia, o que corresponde a cerca de $28,5 \%$ do total de colaboradores especialistas. Foram os especialistas de número 3 e 0 de numero 7. 
De modo geral, as avaliações consideradas consistentes pela metodologia apontam para o Aterro sanitário como a alternativa de maior custo geral, alcançando $47,9 \%$, para $27,5 \%$ de custo geral alcançado pelo tratamento térmico indissociado de RSU e $24,6 \%$ de custo geral para tratamento biológico associado ao tratamento térmico, sendo esta ultima a alternativa preferível em relação às outras. (gráfico 2).

Ao se observar as avaliações, sem desconsiderar consideradas inconsistentes (gráfico 1), para fim de considerar as experiências e tentar compreender o panorama geral exposto, destacam-se os especialista "2" com valores iguais para custo geral do uso de aterros sanitários e para o tratamento biológico associado ao tratamento térmico, com 14,9\% para cada e 70,1\% dos custos gerais apontando para tratamento térmico indiferenciado dos RSU. Uma leitura que se pode fazer é que, segundo este colaborador, é indiferente tratar os resíduos ou lança-los no aterro conforma a situação atual.

Analisando a avaliação do especialista 3 , os valores alcançados para custo geral do aterro sanitário é de $45,5 \%$ e o custo geral de tratamento com biodigestor anaeróbio associado ao tratamento térmico atingem o valor de $42,4 \%$ e por fim o custo geral do tratamento térmico indiferenciado de RSU, num total de $12,1 \%$. Já a avaliação do especialista 7 alcançou valores para custo geral 50,3\% para aterro sanitário, $43 \%$ para tratamento térmico indiferenciado e para tratamento biológico associado ao tratamento térmico de RSU o valor de 6,7\%. (gráfico 2)

Uma outra avaliação é a do especialista "6", que alcançou valores para custo geral o uso de aterro sanitário de $8,7 \%$, para custos de tratamento térmico indiferenciado o custo geral de 20,9\% e para tratamento biológico associado ao tratamento térmico o valor de $70,5 \%$. Estes dados apontam para questões como a manutenção do atual status dos aterros sanitários, ou a inviabilidade geral da associação entre tratamentos biológicos e térmicos para os RSU. (gráficos 1 e 2) 
Um outro destaque é o especialista de numero "5", que embora sua avaliação tenha sido considerado inconsistente pela metodologia, aponta para a solução de menor custo a associação entre tratamentos biológicos e térmicos para os RSU.

O especialista "1" avaliou, segundo a metodologia, o custo geral de tratamento térmico indiferenciado dos RSU como sendo a alternativa de menor valor com 18,6\%, seguido pela associação entre tratamento biológico e térmico com 27,5\%.(gráficos 1 e 2)

Ao se avaliar os resultados de todos os especialistas, sem excluir as avaliações inconsistentes (como já visto) nota-se valores idênticos.

Seguindo esta lógica, estas avaliações foram submetidas a dois cenários diferentes. O primeiro cenário, com uma valorização maior dos custos de implantação. No segundo caso, a valorização foi dos custos dos impactos socioambientais.

Assim, pode-se observar entre as avaliações (sem excluir as inconsistentes), no cenário de valorização dos custos de implantação, os custos gerais de tratamento biológico associado ao tratamento térmico os valores $23,1 \%$, $21,2 \%, 25,1 \%, 20,7 \%$ e $7,2 \%$ segundo os especialistas 1, 2, 3, 5 e 7 . Tais avaliações apontam a viabilidade desta solução. Contudo, ainda neste cenário, os especialistas 2 e 6 apontam o aterro sanitário, como alternativa de menores custos gerais (gráfico 3).

Agora no cenário de valorização dos impactos socioambientais (gráfico 5), as avaliações dos especialistas 2, 5 e 7, os custos gerais para o tratamento biológico associado ao tratamento térmico são respectivamente 8,6\%, 14,9\% e $6,3 \%$. Os especialistas 1 e 3 apontam para o tratamento térmico os custos gerais de $28,4 \%$ e $14,8 \%$. E como alternativa de menor custo geral o aterro sanitário o especialista 6 com valor $7,5 \%$. 
Assim, para efeito de comparação dos 3 cenários (gráficos 1, 3 e 5) que os resultados se mantem semelhantes em relação aos custos gerais para as alternativas apresentadas por este trabalho. Todavia, para os cenários com apenas as avaliações consistentes, nota-se no gráfico 2 (cenário avaliado) que as alternativas de tratamento biológico e o tratamento térmico indissociado dos RSU estão próximas dentro dos valores de custo geral médio, com $24,6 \%$ e $27,5 \%$ respectivamente.

Para o cenário cujo custo de implantação foi expressivamente superior (gráfico 4), a tendência de escolha o tratamento biológico associado ao tratamento térmico a solução mais adequada com menor custo geral, alcançando $16,2 \%$ e com $34,1 \%$ o tratamento térmico indissociado de RSU (mais que o dobro). E para o cenário de valorização dos custos de impactos socioambientais (gráfico 6), o tratamento térmico indissociado dos RSU são a opção de menor custo geral, com 20,9\% e o tratamento biológico associado ao tratamento térmico com $33 \%$. Cabe destacar que nestes 2 cenários hipotéticos, o aterro sanitário foi a alternativa de maior custo geral.

Como a avaliação é voltada ao custo, valores maiores representam custos elevados, ou utilizando a nomenclatura dos formulário (Apêndice II), custos superiores. Assim, segundo este especialista, o uso de aterros sanitário teria um custo quase igual à utilização de tratamento biológico e tratamento térmico dos RSU.

Como opção de tratamento biológico, há o biodigestor, a compostagem e a vermicompostagem (como um processo de melhoramento da compostagem). No primeiro caso, o biodigestor quando misturados insumos oriundos de RSU são indicados para tratar grandes volumes (Li, Park e Zhu; 2011; Anitha et al.; 2015), Scano et al. (2014), Jin et al. (2015). Podendo inclusive ser associado ao tratamento de esgotos (MASSOTI, 2002). Os custos de implantação e dos impactos socioambientais podem ser amenizados com a recuperação energética a partir da geração e da queima do biogás (ALVES et al., 2014), bem como, a partir da utilização do fertilizante gerado ao fim do processo KU- 
ROKI (2008). Corroborando com este panorama, há a facilidade de encontrar materiais para a construção de biodigestores, que consistem em materiais de alvenaria, onde o único elemento que pode encarecer este tratamento são as mantas de PVC (TORRES; PEDROSA; MOURA, 2012).

Para a compostagem, a parte orgânica putrescível dos RSU também pode ser tratada através desta tecnologia (Oviedo-Ocaña et al; 2015), (Pan, Dam e Sem; 2011). Ressaltando a necessidade da segregação dos resíduos na fonte geradora. Há a possibilidade desta tecnologia se tornar menos custosa com subsídios públicos (Ince et al; 2016). Há casos de sucesso na utilização desta tecnologia no tratamento de RSU, como o caso do Canadá (HÉNAULTETHIER et al.; 2016) e em São Paulo (Siqueira e Assad; 2016) se aplicada de modo descentralizado, culminando na redução expressiva dos custos. O uso de minhocas pode aperfeiçoar este processo (Bidone e Povinelli; 2010; HÉNAULT-ETHIER et al; 2016), com a destruição de patógenos que porventura estejam presentes nos RSU. Contudo, o uso de minhocas possa trazer uma necessidade de manutenção maior e de investimento de recursos financeiros para a aquisição das mesmas.

Assim, o especialista 7 esta de acordo com estes autores, pois os tratamentos biológicos de um modo geral tem custos bem menores quando comparados às demais alternativas deste trabalho. Contrariando o especialista 3 , que aponta o tratamento térmico como o menos custoso de modo geral.

O tratamento térmico, na realidade deste trabalho, pode ser compreendido como a via tecnológica que inclui a incineração, a pirólise, a queima a plasma e o beneficiamento de resíduos com alto poder calorifico, os chamados CDR (combustível derivado de resíduos) (Barros; 2013; Calijuri e Cunha; 2013).

Quando comparados aos tratamentos biológicos, a incineração é um processo expressivamente mais rápido (durando minutos quando os processos biológicos demoram dias) (Morgado e Teixeira; 2006) com redução do volume total dos RSU (Juca et al; 2013). O processo conhecido como mass burning 
está associado à queima de RSU de modo indiferenciado com baixa recuperação energética (FEAM, 2010).

Embora tecnologicamente viável, tem um alto custo de instalação, de manutenção e trazer pouco retorno na recuperação energética, além de geração de dioxinas e furanos (Olie et al; 1977; Buekens e Huang; 1998; McKay; 2002), segundo os autores citados.

Tal condição reforça a necessidade de segregarem-se os RSU na origem, pois, além de reduzir o custo do tratamento, possibilitam que o tratamento seja mais eficiente quanto ao aspecto da recuperação energética. $O$ uso de material com alto poder calorifico (combustível derivado de Resíduos ou CDR) pode ser beneficiado ao ser seco, triturado e compactado para ser estocado e transportado para queima futura, com recuperação energética (Juca et al; 2013).

Outra forma de recuperação energética são os processos térmicos de Gaseificação, com a geração do gás de síntese ou Syngas (FEAM, 2013) e da pirólise (Younan et al; 2016).

Por fim, o processo de tratamento térmico que melhor estabiliza os RSU transformando-os em escoria vitrificada e gases simples é a queima a plasma (Sun et at , 2013). Contudo, é o tratamento mais caro e que mais consome energia.

A partir dessas condições, pode-se constatar que o tratamento térmico acaba por encarecer o processo. Como os tratamentos biológicos são mais baratos, e a matéria orgânica putrescível compondo cerca de 51,4\% dos RSU (Abrelpe, 2015a), uma menor carga destes resíduos com uma melhor recuperação energética concorrem para a redução dos custos gerais das tecnologias de tratamento apresentadas.

Quanto às notas solicitadas fornecidas pelos especialistas colaboradores através do mesmo formulário (Apêndice II) para o custo de coleta, numa avali- 
ação direta, onde se foram avaliados os custos de coleta com segregação de RSU e a coleta sem a segregação, o gráfico 7 apresenta média de 5,43 pontos para coleta sem segregação e 5,57 pontos para coleta com segregação. Cabe ressaltar que notas menores refletem custos maiores, e notas maiores refletem custos menores.

Custo de Coleta

\begin{tabular}{|c|c|c|c|c|c|c|c|}
\cline { 2 - 8 } \multicolumn{1}{c|}{} & Esp. 1 & Esp. 2 & Esp. 3 & Esp. 4 & Esp. 5 & Esp. 6 & Esp. 7 \\
\hline $\begin{array}{c}\text { Coleta sem segre- } \\
\text { gação de RSU }\end{array}$ & 4 & 3 & 8 & 2 & 4 & 8 & 9 \\
\hline $\begin{array}{c}\text { Coleta com segre- } \\
\text { gação de RSU }\end{array}$ & 7 & 6 & 5 & 6 & 8 & 3 & 4 \\
\hline
\end{tabular}

\begin{tabular}{|c|c|c|c|c|c|}
\hline & \multirow[b]{2}{*}{ Moda } & \multirow[b]{2}{*}{ Média } & \multirow[b]{2}{*}{ Desv. Padrão } & \multicolumn{2}{|c|}{ Intervalo de variação } \\
\hline & & & & + & - \\
\hline $\begin{array}{c}\text { Coleta sem segregação } \\
\text { de RSU }\end{array}$ & 4 & 5,43 & 2,82 & 8,25 & 2,61 \\
\hline $\begin{array}{c}\text { Coleta com segregação } \\
\text { de RSU }\end{array}$ & 6 & 5,57 & 1,72 & 7,29 & 3,85 \\
\hline
\end{tabular}

Tabela 19 - Consolidado do gráfico 7 com testes de Moda e desvio Padrão.

Desta forma, como já observado, pode-se compreender como praticamente idênticas em termos de custo para coleta com segregação de Resíduos e sem a mesma segregação. Contudo, ao se observar as avaliações, pode estar sugerido que as notas estariam mais homogêneas quanto ao custo da coleta com segregação, posto que numa avaliação de MODA, o especialista 2 e o especialista 4 atribuem o mesmo custo para coleta com segregação, 6 pontos (tabela 19). Para o custo de coleta sem segregação, no mesmo teste de MODA, surgem as avaliações dos especialistas 1 e 5, com 4 pontos e as notas dos especialistas 3 e 6 com 8 pontos. Ainda neste contexto, os especialistas 2 com 3 pontos e o especialista 7 com 9 pontos, podem sugerir que não exista um consenso entre os especialistas sobre o custo de coleta sem segregação de RSU. (testes realizados no software de planilhas eletrônicas Excel 2010). Ideia 
reforçada a partir do calculo do desvio padrão, apontando para uma variação de 2,82 pontos para custo de coleta sem segregação, e de 1,72 para o custo de coleta com segregação de RSU.

A partir da consolidação das avaliações para o custo de implantação, o gráfico 8 apresenta novamente valores idênticos. Neste caso, o custo médio da implantação de um incinerador é igual ao custo de implantação de um biodigestor anaeróbio, com 4,43 pontos, com 2 pontos a menos na media do que a implantação de um aterro sanitário, com 6,43 pontos.

Custo de Implantação

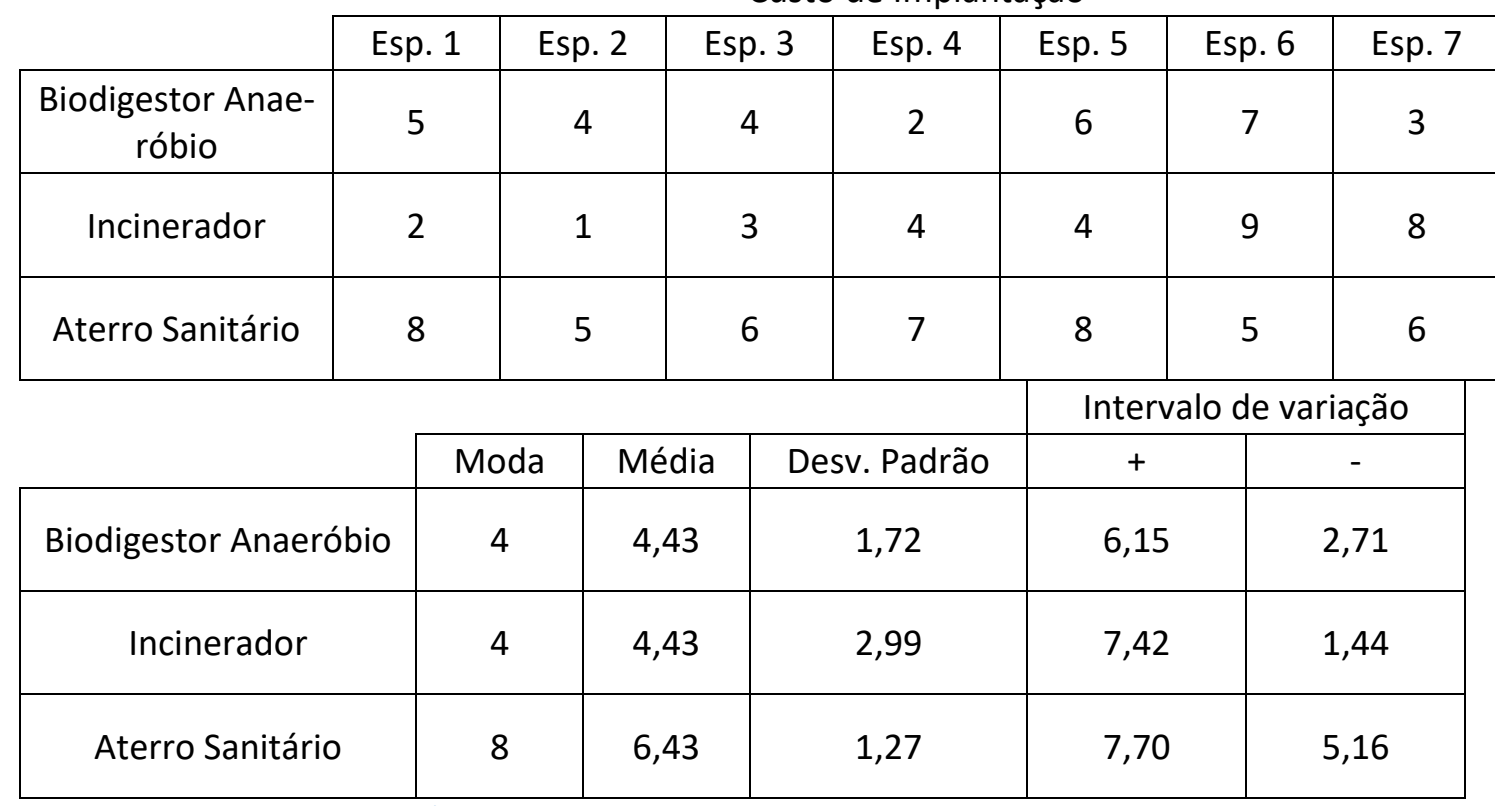

Tabela 20 - Consolidado do gráfico 8 com testes de Moda e desvio Padrão.

Todavia, após um teste de MODA entre as avaliações, surgem as notas 4 como as mais frequentes para o custo de implantação das tecnologias de tratamento, e nota 8 como nota mais frequente para custo de implantação de aterros sanitários. Além deste teste, foi calculado o desvio padrão, a fim de perceber as variações na pontuação. Desta forma, a avaliação de maior desvio foi no custo de implantação de incinerador, com quase 3 pontos $(2,99)$.

Pode-se observar que, segundo a avaliação dos especialistas, o custo da implantação de um incinerador pode variar de 7,42 a 1,44. O custo de implantação de um biodigestor anaeróbio pode variar de 6,15 a 2,71, com um 
desvio padrão de 1,72 pontos. E para a implantação de um aterro sanitário, a variação de notas ficou em 1,27 pontos. De forma geral, na avaliação dos especialistas o custo de implantação de aterro sanitário varia entre 7,7 e 5,16. Isso aponta para alto custo, sendo que o menor valor se encontra acima de 5 pontos. Esta avaliação pode dialogar com Vital et al (2014), que considera a disposição inadequada dos RSU, já que o encaminhamento destes resíduos para aterro sanitário sem tratamento, aumentam o gasto com monitoramento e tratamento de percolado e captação de gases. Corroborando com isso está MANNARINO et al (2016).

Por fim, a consolidação das avaliações dos especialistas para os custos dos impactos socioambientais apontam para uma média de 6 pontos como resultado da operação de incineradores. Já os impactos causados pela operação de biodigestores anaeróbios alcançaram 5,57 pontos. E o aterro sanitário aparece como a alternativa com menores impactos socioambientais, com 4,29 pontos.

Custo dos Impactos socioambientais

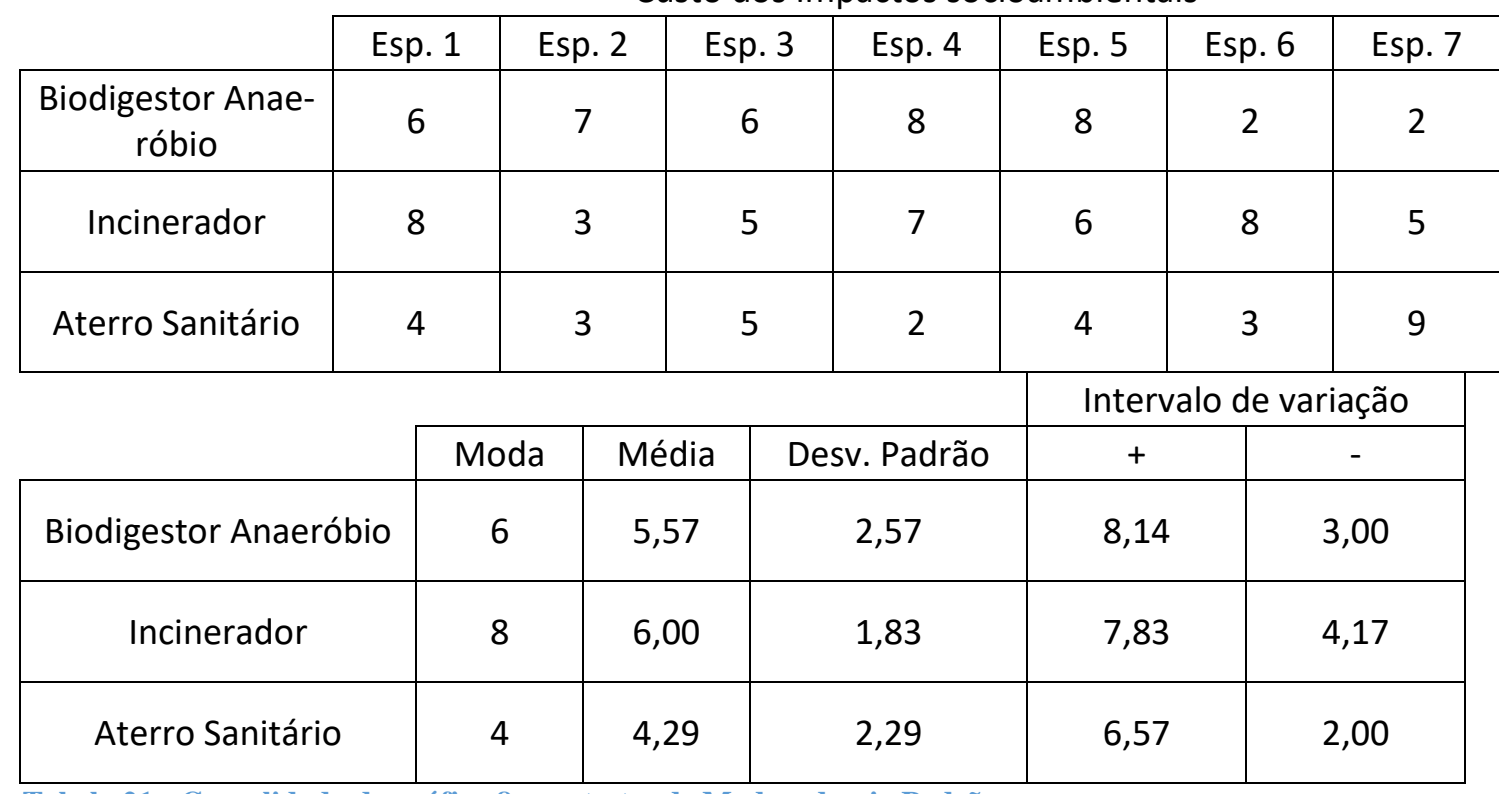

Tabela 21 - Consolidado do gráfico 8 com testes de Moda e desvio Padrão.

A partir desta avaliação, foi aplicado o teste de MODA para cada uma das alternativas. Foram alcançados como valores mais frequentes para o custo dos impactos socioambientais do biodigestor anaeróbio a nota 6 , para o incine- 
rador a nota 8 e para o aterro sanitário a nota 4 . Tais valores sugerem que 0 incinerador, segundo os avaliadores, é uma tecnologia que causa mais impactos socioambientais, o que dialoga com a literatura (Olie et al; 1977; Buens e Huang; 1998; Gouveia; 2012; FEAM; 2012; Lopes et al; 2015). O desvio padrão aponta para uma variação menor no entendimento dos especialistas para o incinerador. $\mathrm{O}$ aterro e $\mathrm{o}$ biodigestor trazem variações maiores $(2,29$ e 2,57 respectivamente). 


\section{CONSIDERAÇÕES FINAIS}

A Política Nacional de Resíduos Sólidos ainda não esta sendo respeitada. Muitas de suas exigências e parâmetros não são aplicados. Todavia, é absolutamente necessário que o poder público, em sua obrigação de zelar pelo ordenamento jurídico e pelo bem comum, tome providencias de modo a responsabilizar os envolvidos nos processos produtivos que são os grandes geradores de resíduos, de modo a participarem ativamente dos tratamentos de RSU que os mesmos contribuem ativamente a gerar.

Uma crítica precisa ser feita a respeito da atualização dos dados a partir de fontes consultadas, considerando que o Diagnóstico dos Resíduos Sólidos Urbanos realizado pelo IPEA (Instituto de Pesquisa Econômica Aplicada) (IPEA, 2016) tem sua publicação no ano de 2012, utilizando como base, dados do IBGE de 2008 (Pesquisa Nacional de Saneamento Básico) (IBGE, 2010), publicada em 2010.

Já o Sistema Nacional de Informações sobre Saneamento (SNIS), que é vinculado ao Ministério das Cidades, é apresentado como o "...maior e mais importante sistema de informações do setor de saneamento brasileiro." É alimentado pelos prestadores de serviço oficiais. Sua publicação mais recente é Diagnóstico do Manejo de Resíduos Sólidos Urbanos de 2015, cuja data de divulgação e disponibilização foi dia 03/04/2017 (SNIS, 2017).

Um sistema de gerenciamento deve (e precisa ser) integrado, atualizado e robusto a fim de auxiliar aos gestores em suas ações de modo a tratar com situações reais e concretas. Ações baseadas em condições e diagnósticos desatualizados podem comprometer os resultados de modo negativo, potencializando problemas e consumindo recursos desnecessariamente.

Isto posto, a PNRS faz referencias claras ao uso de aterros, onde somente seriam dispostos neste os rejeitos, i.e., os resíduos que após esgotadas 
todas as possibilidades de tratamento deveriam ser nele lançados. Desta for$\mathrm{ma}$, a reciclagem é um procedimento anterior aos aterros. Bem como a recuperação energética a partir dos resíduos. Os tratamentos devem ser realizados de modo que os resíduos tratáveis que não cheguem aos aterros.

Como norteador, pode-se utilizar a Diretiva de Aterros Sanitários 1999/31/CE, criada e aplicada pela Comissão Europeia, que estipula metas para os países membros, os quais devem reduzir em até 50\% a disposição final de resíduos putrescíveis em seus aterros sanitários. Embora ainda seja uma realidade distante da brasileira, posto a existência de lixões reconhecidos pelo poder público, além dos clandestinos.

Cerca de $50 \%$ dos RSU é formado por matéria orgânica, a qual está confinada em aterros, sendo a responsável pela geração descontrolada de metano e pela geração de percolado contaminante, causando maiores gastos com monitoramento, ações de controle e mitigação, além do aumento dos custos e diminuição da vida útil do mesmo. Se a mesma matéria orgânica não for disposta em aterros, o problema do chorume e da emissão de gases de efeito estufa estará resolvida.

A combinação de tecnologias para tratamento da porção orgânica dos RSU é demasiado importante para que não seja difundida e aplicada em todas as suas formas. A segregação dos resíduos na fonte geradora, a recuperação energética dos resíduos através da incineração pode auxiliar o pais a combater as variações na demanda energética nacional, promovendo o crescimento do próprio setor produtivo.

O custo dos empreendimentos não deve ser um argumento contrário a aplicação das tecnologias disponíveis, pois há a responsabilidade objetiva dos envolvidos e o consumidor final não pode responder individualmente na geração dos RSU, considerando todo o contexto em que estão inseridos. Há tecnologias de baixo custo que podem ser associadas ao gerenciamento dos RSU. Os formulários encaminhados aos especialistas se referiam a cidades com cerca de 200 mil habitantes, sendo que, para efeito deste trabalho, foram conside- 
radas cidades em três tamanho: até 100 mil habitantes, de 100 mil a 500 mil habitantes e acima de 500 mil habitante. Portanto, já apontava para possíveis soluções consorciadas, considerando que $95,5 \%$ dos municípios brasileiros possuem até 100 mil habitantes (IBGE, 2008).

É relevante avaliar a logística presente na coleta dos resíduos sólidos urbanos, onde os resíduos coletados possuem cerca de 50\% de matéria orgânica putrescível. Esta condição gera o chamado chorume, que pode ser observado cotidianamente durante a coleta publica. Este chorume, resultado da fermentação desta matéria por ação de bactérias ali presentes, cai nas vias publicas. Além do mau cheiro, estes resíduos cai nos sistema de drenagem da cidade. Devido ao fato do Brasil adotar o sistema separador absoluto, a drenagem de águas pluviais conduz tais substancias para rios, córregos, e no caso da zonal sul da cidade, desemboca nas praias. Tal condição é uma das causas das chamadas línguas negras verificadas nas praias cariocas, que são intensificadas nos períodos chuvosos.

De modo escalonado, podem-se programar etapas para a resolução destes problemas. A citar: A) Extinção de lixões e conversão de aterros controlados em aterros Sanitários. B) Estabelecer a segregação de resíduos na fonte geradora como prioridade das ações do governo - através de ações educativas ou fomentadoras, ou ambas. C) Associação entre governos e pessoas jurídicas através de parcerias público-privadas ou soluções consorciadas para a construção, operação e manutenção dos equipamentos de tratamento e transparência publica em todos os níveis do empreendimento. D) Utilização de soluções combinadas de tratamento para resíduos sólidos orgânicos putrescíveis (biodigestor aeróbio e compostagem de modo atomizado sempre que possível e incineração com recuperação energética para os demais). E) Valorização dos resíduos através de fomentos públicos.

É fator de extrema relevância que ainda existam lixões e aterros controlados em funcionamento. Nestes ambientes, ocorrem de modo agravado o mesmo fenômeno observado durante a coleta. Todavia, o liquido resultante do processo de fermentação nestes ambientes é chamado de lixiviado. Tal sub- 
produto contamina o solo e as águas subterrâneas. Como resultado desta contaminação há diarreias, infecções cutâneas, aparecimento de vetores (moscas e ratos). Os lixões e aterros controlados ainda acabam por ser focos de doenças epidemiológicas como por exemplo dente, chikungunia, zika.

Já entre os rejeitos sólidos, pode-se observar os rejeitos eletrônicos que vão desde baterias até circuitos integrados. Vários componentes que não possuem tratamento viável sob a ótica econômica, e desta forma são acumulados. Carcaças de automóveis, bens de consumo, embalagens ao fim de sua vida útil se tornam inservíveis. Plásticos que não possuem valor comercial, entre outros resíduos acabam por não ser reciclados pelo fato da coleta seletiva ainda ser uma ação incipiente no país.

Sobre a metodologia, a análise multicritério AHP se mostra um valoroso instrumento de auxílio a tomada de decisão. Contudo, não pode ser considerada como absolutamente determinante pois, segundo este trabalho, apresenta limitações que podem desconsiderar tendências sutis inerentes às escolhas dos colaboradores, pois devido a validação da consistência de cada avaliação, a sensibilidade do especialista, que não é um critério lógico necessariamente, pode ser descartada e com isso, sua experiência ao avaliar uma dada situação, não terá relevância.

Quanto a aplicação neste trabalho, a metodologia de análise AHP, se mostrou pratica mas pouco efetiva, pois se estruturou a partir da consulta de 7 especialistas. Todavia, após a avaliação de consistência, 5 foram descartadas, sendo apenas 2 consideradas. Duas avaliações não representam a maioria das avaliações aqui utilizadas, e ainda assim, não houve consenso entre eles quanto aos custos gerais (coleta, implantação e dos impactos socioambientais).

Desta maneira, a aplicação da metodologia não foi conclusiva, pois fica evidenciado que não houve consenso entre os avaliadores a partir dos resultados dos formulários. Tal condição pode ter sido causada por interpretações equivocadas dos formulários; a não compreensão do próprio método; pela 
forma de apresentação do questionário (tabela 18). Como sugestão, pode ser realizado um pré-teste com o acompanhamento do pesquisador.

Assim, trata-se de uma ferramenta poderosa, mas exige de seu usuário um olhar atento, e mesmo aplicando a metodologia conforme sua descrição exige, não pode ser a única responsável pela escolha. $O$ olhar atendo e critico do seu usuário é o elemento determinante para o resultado. Além disso, pode ser recomendado uma adaptação desta metodologia à necessidade de incluir outros atores que possam estar envolvidos no processo de decisão.

Quanto a questão efetiva dos tratamentos de RSU, os tratamentos térmicos, que neste trabalho compreendem as tecnologias de incineração, gaseificação, pirólise, queima a plasma e combustível derivado de resíduos, geram emissões atmosféricas. Gás carbônico é o principal componente ao se considerar o processo de queima funcionando plenamente, em condições ideais (excetuando-se a queima a plasma que emite oxigênio, hidrogênio e vapor d'água, além de metais pesados e gases ácidos). Todavia, outras substâncias podem estar presentes, como compostos a base de enxofre, monóxido de carbono e oxido nítrico, entre outras. Tal condição deve ser considerada soba perspectiva de mau funcionamento, falta de manutenção ou precariedade da mesma, pois não é uma condição atípica verificada em países em processo de industrialização.

A incineração como tratamento térmico se associada com a separação com valorização dos resíduos, o potencial de geração de energia se torna mais eficiente, seguindo a tendência internacional da visão waste-to-energy, ou reciclagem energética de resíduos. Cabe salientar que a incineração, embora não seja o processo mais eficiente, é o que apresenta a melhor relação volume $X$ custo para tratamento.

O tratamento a plasma seria o mais eficiente em relação aos impactos ambientais, pois gera subprodutos estáveis e inertes a um custo maior. A gasificação seria uma alternativa que demandaria maior controle e regulação nos 
resíduos utilizados além de uma maior capacitação das equipes de funcionários envolvidos.

A pirólise pode ser um tratamento que apresenta maiores opções no que diz respeito aos subprodutos do tratamento.

A incineração é um caminho, que tal como realizado na Europa, é capaz de reduzir significativamente o volume de resíduos nos aterros, além de atender o que diz a legislação, como disposto na PNRS em seu art. $3^{\circ}$, itens VII, VIII e XV, desde que os procedimentos de controle de emissões e ações preventivas sejam rigorosamente adotados e monitorados.

Os tratamentos biológicos, que neste trabalho compreendem a compostagem, vermicompostagem e o biodigestor, também emitem $\mathrm{CO}_{2}$, metano e gases a base de enxofre (estes dois de modo mais relevante nos biodigestores). Embora o metano possa ser utilizado para fins de recuperação energética, é necessário que sejam consideradas as mesmas condições de mau funcionamento em decorrência das mesmas causas. Cabe ressaltar que tanto o gás carbônico quanto o metano são gases de efeito estufa e contribuem para a poluição atmosférica.

Todavia, pode-se considerar a possibilidade de residências que possam dispor de áreas como quintais ou espaços amplos poderiam adotar a compostagem ou a vermicompostagem como tratamentos que podem traz um benefício duplo: segregação na fonte (reduzindo assim a parcela contaminante de matéria orgânica putrescível) e tratamento local dos RSU de modo a reduzir o custo com a logística de coleta e transporte dos mesmos. E a utilização de biodigestores ter um aporte de investimentos tanto em pesquisa quanto em utilização para grandes volumes de RSU, considerando a redução do volume de matéria orgânica putrescível.

É importante ressaltar que o princípio que rege a PNRS é o principio do poluidor pagador. Desta forma, todos os participantes envolvidos desde a produção ao consumo são solidários na responsabilidade junto ao ambiente no 
que tange a geração de resíduos. Todavia, como torna-se impossível em muito casos devolver ou ate mesmo identificar o produtor ou fabricante dos produtos de consumo, a inevitável cobrança recai sobre o consumidor final de destinar corretamente os resíduos segregando-os em seu ponto de consumo (residências em grande parte dos casos).

Como os setores produtivos são os grandes motivadores do consumo para que se aumentem as vendas e, portanto a produção, são também os provocadores da sociedade, que através de propaganda e estratégias de marketing, fomentam o consumo, e, por conseguinte a geração de resíduos numa escala que tende a aumentar.

Desta forma, ante a legislação, reforçada pelos princípios da sustentabilidade, seria lógico e aceitável atribuir a responsabilidade pela coleta, tratamento e disposição final dos rejeitos também aos produtores. Uma saída aos municípios seria a parceria publico privada para a instalação de estruturas capazes de tratar os resíduos conforme a natureza do gerador.

Melhor dizendo, ao setor da agroindústria caberiam ações e investimentos relacionados à reciclagem de resíduos sólidos orgânicos. Podendo participar do retorno com o respectivo aproveitamento energético ou com insumos para quem eles mesmos possam utilizar (fertilizantes). O mesmo pode ser proposto para os demais setores industriais. Principio da logística reversa conforme descrito na PNRS, em seu art. $3^{\circ}$, item XII.

Além destes recursos, as soluções consorciadas entre municípios e demais entes públicos poderiam continuar vigentes. Seriam mais alternativas a serem disponibilizadas. 


\section{REFERÊNCIAS}

ABIKO, Alex Kenya; ALMEIDA, Marco Antonio Plácido de; BARREIROS, Mário António Ferreira. Urbanismo: história e desenvolvimento. São Paulo: EPUSP, 1995. Disponível em: http://reverbe.net/cidades/wpcontent/uploads/2011/08/urbanismo-historiaedesenvolvimento.pdf

ABRELPE - Associação Brasileira de Empresas de Limpeza Pública e Resíduos Especiais (Sp). Estimativas dos Custos Para Viabilizar A Universalização da Destinação Adequada de Resíduos Sólidos no Brasil. São Paulo: Abrelpe, 2015a. 48 p. Disponível em: http://www.abrelpe.org.br/arquivos/pub estudofinal 2015.pdf

ABRELPE - Associação Brasileira de Empresas de Limpeza Pública e Resíduos Especiais (São Paulo). Panorama dos Resíduos Sólidos no Brasil 2015. Sp: Abrelpe, 2015b. 92 p.

AFONSO, C. et al. Avaliação e Otimização de Biodigestor. [s.d.].

ANITHA, M. et al. Determination of bio-methanol as intermediate product of anaerobic co-digestion in animal and agriculture wastes. International Journal Of Hydrogen Energy, [s.I.], v. 40, n. 35, p.11791-11799, set. 2015. Elsevier BV. http://dx.doi.org/10.1016/j.jihydene.2015.06.072.

ALENCAR JÚNIOR, Nehemias Rodrigues; GABAÍ, Isaac. Incineração e dioxinas: análise do aporte teórico disponível. 2001. Disponível em: http://www.abepro.org.br/biblioteca/ENEGEP2001 TR104 0410.pdf

AlVARENGA, R. A. M. et al. Arranjo Produtivo Local E Desenvolvimento Sustentável: Uma Relação Sinérgica No Município De Marco. Revista de Adminis- 
tração Mackenzie (RAM), v. 14, n. 5, p. 15-43, 2013. Disponível em: http://editorarevistas.mackenzie.br/index.php/RAM/article/viewFile/5088/4488

ALVES, Marceluci de Oliveira et al. Biodigestores: Fonte Renovável de Energia. In: MOSTRA INTERNA de TRABALHOS de INICIAÇÃO CIENTÍFICA, 2014, Maringá - Pr. Anais Eletrônicos. Maringá - Pr: Cesumar, 2014. v. 7, p. 1 - 5. Disponível

em: http://www.cesumar.br/prppge/pesquisa/epcc2013/oit mostra/Marceluci de Oli veira Alves.pdf. Acesso em: 25 mar. 2016.

AMARAL, G. et al. Compostagem Para Gestão de Resíduos Sólidos Orgânicos: p. $\quad 1-5, \quad 2015.2$ Disponível em: http://www.ibeas.org.br/congresso/Trabalhos2015/l-014.pdf

ANDRADE, R. V. Gaseificação de Biomassa: Uma Análise Teórica e Experimental. Universidade Federal De Itajubá Instituto De Engenharia Mecânica Programa De Pós-Graduação Em Engenharia Mecânica, p. 227, 2007. Disponível em: http://saturno.unifei.edu.br/bim/0032784.pdf

ANTAS JR., R. M. O consumo contemporâneo no território brasileiro. In: ANTAS JR., R. M. et al. (Org.). Desafios do consumo. Petrópolis, RJ: Vozes, 2007, p. 91-102.

ARAÚJO, J. C. A. Histopatologia da interação Alternaria solani e tomateiros resistente e suscetível. Fitopatol. Bras., v. 29, n. 92, p. 268-275, 2004. ITO, M. A. Patogenicidade de Fusarium oxysporum f. sp. phaseoli, adubação nitrogenada e produtividade de feijão. p. 61, 2004. Disponível em: http://www.scielo.br/pdf/fb/v29n3/20360.pdf

ABNT - ASSOCIAÇÃO BRASILEIRA DE NORMAS TÉCNICAS. NBR 13.896: Aterros de Resíduos não Perigosos - Critérios para Projeto, Implantação E Operação. Rio de Janeiro: Abnt, 1997. 12 p. Disponível em: http://licenciadorambiental.com.br/wp-content/uploads/2015/01/NBR-13.896- 
ABNT - ASSOCIAÇÃO BRASILEIRA DE NORMAS TÉCNICAS. NBR 8.419: Apresentação de Projetos de Aterros Sanitários de Resíduos Sólidos Urbanos. Rio de Janeiro: Abnt, 1996. 7 p. Disponível em: https://www.observatorioderesiduos.unb.br/painel/assets/uploads/files/996denbr-8.419-nb-843-apresentacao-de-projetos-de-aterros-sanitarios-rsu.pdf

ASTM - American Society for Testing and Materials - Combustível ASTM E85683 (1998), Definições Padrão De Termos E Abreviaturas Relativas Às Características Físicas E Químicas Dos Resíduos Derivado, ASTM International, West Conshohocken, PA, 2006, www.astm.org. Disponivel em: https://www.astm.org/DATABASE.CART/HISTORICAL/E856-83R98.htm

AYAG, Z. A Fuzzy AHP-based Simulation Approach to Concept Evaluation in a NPD Environ- ment, IIE Transactions, v. 37, pp. 827-842, 2005. Disponível em: http://xa.yimg.com/kg/groups/21453266/606960682/name/A+fuzzy+AHP-

$\underline{\mathrm{ba}-}$

$\underline{\text { sed+simulation+approach+to+concept+evaluation+in+a+NPD+environment.pdf }}$

AZEREDO, J.S.; Paula Junior, G.G.; SANTOS, R.B.O.; BARRETO, D.N.S. \& GONÇALVES, T.J.M. Utilização Do Método De Análise Hierárquica (AHP) Para A Seleção De Um Sistema Integrado De Gestão (ERP). XXIX Encontro Nacional de Engenharia da Produção. Salvador $(\mathrm{BH}), 2009$. Disponível em: https://www.researchgate.net/profile/Tiago Goncalves/publication/224874577 Utiliza-

cao do Metodo de Analise Hierarquica AHP para a Selecao de um Siste ma Integrado de Gestao ERP/links/0fcfd4fa13a5166d17000000/Utilizacaodo-Metodo-de-Analise-Hierarquica-AHP-para-a-Selecao-de-um-SistemaIntegrado-de-Gestao-ERP.pdf

BARCELOS, Beatriz Rodrigues de. Avaliação De Diferentes Inóculos Na Digestão Anaeróbia Da Fração Orgânica De Resíduos Sólidos Domésticos. 2009. 89 f. Dissertação (Mestrado) - Curso de Tecnologia Ambiental e Recursos Hídricos, Engenharia Civil e Ambiental, Universidade de Brasília, DF, 2009. Dispo- 
nível

em:

http://repositorio.unb.br/bitstream/10482/4619/1/2009 BeatrizRodriguesBarcelo s.pdf. Acesso em: 24 mar. 2016.

BARROS, Regina Mambeli. Tratado sobre Resíduos Sólidos: Gestão, uso e sustentabilidade. Rio de Janeiro: Editora Interciência Ltda, 2013. 374 p.

BARROS, Renata Tp; Costa, Tatiana Dr. Avaliação da compostagem de carcaças de frango pelos métodos da composteira e de leiras estáticas aeradas Ed Carlo R. Paiva, Antonio T. De Matos 2, Mônica A. Azevedo 3. 2012. Disponível em: http://www.scielo.br/pdf/eagri/v32n5/15.pdf

BASTOS, Valeria Pereira; MAGALHÃES, Andrea Oliveira. Lixão de Gramacho: Impactos do encerrameto para os catadores. Temporalis, v. 16, n. 31, p. 379398, 2016. Disponível em: http://periodicos.ufes.br/temporalis/article/download/12351/10113

BERRÍOS, Manuel Rolando. Consumismo e geração de resíduos sólidos. GEOUSP: Espaço e Tempo (Online), São Paulo, n. 6, p. 17-28, aug. 2006. ISSN 2179-0892. Disponível em: $<$ http://www.revistas.usp.br/geousp/article/view/123360/119696>. Acesso em: 10 mar. $2017 . \quad$ doi:http://dx.doi.org/10.11606/issn.21790892.geousp.1999.123360.

BESTEIRO, A.M., et al. [S.D.]. A Utilização Do Método AHP Para Traçar, Como Ferramenta Para O Auxilio A Decisão De Um Candidato, A Escolha De Um Curso De Engenharia. Universidade Estadual Paulista - UNESP. Disponível em: http://let.aedb.br/seget/artigos09/226 Artigo - AHP Engenharia.pdf Acesso em: 04 jan. 2017

BRAGA, A. L. M. et al. Aplicação Do Método AHP Para A Hierarquização Das Alternativas De Tratamento De Resíduos Sólidos Domiciliares. Associação Nacional de Tecnologia do Ambiente Construído - ANTAC, v. 11, n. 2, p. 173-187, 2011. Disponivel em: http://www.scielo.br/pdf/ac/v11n2/a12v11n2.pdf 
BRASIL. Lei № 6.938, De 31 De Agosto De 1981. Dispõe Sobre A Política Nacional Do Meio Ambiente, Seus Fins E Mecanismos De Formulação E Aplicação, E Dá Outras Providências. Política Nacional do Meio Ambiente. Brasília, DF, $31 \quad$ ago. $1981 . \quad$ Disponível em: http://www.planalto.gov.br/ccivil 03/leis/L6938.htm. Acesso em: 05 ago. 2015.

BRASIL. Lei № 11.445, De 5 De Janeiro De 2007. Estabelece Diretrizes Nacionais Para O Saneamento Básico; Altera As Leis Nos 6.766, De 19 De Dezembro De 1979, 8.036, De 11 De Maio De 1990, 8.666, De 21 De Junho De 1993, 8.987, De 13 De Fevereiro De 1995; Revoga A Lei No 6.528, De 11 De Maio De 1978; E Dá Outras Providências. Lei № 11.445, de 5 de Janeiro de 2007. Brasília, BRASÍLIA, Disponível em: http://www.planalto.gov.br/ccivil 03/ ato2007-2010/2007/lei/111445.htm. Acesso em: 07 set. 2016.

BRASIL. Lei № 8.080, De 19 De Setembro De 1990. Dispõe Sobre As Condições Para A Promoção, Proteção E Recuperação Da Saúde, A Organização E O Funcionamento Dos Serviços Correspondentes E Dá Outras Providências.. Lei № 8.080, de 19 de Setembro de 1990. Brasília, DF, Disponível em: http://www.planalto.gov.br/ccivil 03/leis/L8080.htm. Acesso em: 05 ago. 2016.

BRASIL. Lei № 12.305, De 02 De Agosto De 2010. Institui A Política Nacional De Resíduos Sólidos; Altera A Lei No 9.605, De 12 De Fevereiro De 1998; E Dá Outras Providências. Política Nacional de Resíduos Sólidos. Brasília , DF, 03 ago. 2010. Disponível em: http://www.planalto.gov.br/ccivil 03/ ato20072010/2010/lei/l12305.htm

BRASIL. Decreto № 7.404, De 23 De Dezembro De 2010. Regulamenta A Lei No 12.305, De 2 De Agosto De 2010, Que Institui A Política Nacional De Resíduos Sólidos, Cria O Comitê Interministerial Da Política Nacional De Resíduos Sólidos E O Comitê Orientador Para A Implantação Dos Sistemas De Logística Reversa, E Dá Outras Providências. Regulamentação da Política Nacional de Resíduos Sólidos. Disponível em: 
http://www.planalto.gov.br/ccivil 03/ ato2007-2010/2010/decreto/d7404.htm.

Acesso em: 05 out. 2016.

BRASIL. Ministério da Agricultura, Pecuária e Abastecimento. Plano Setorial De Mitigação E De Adaptação Às Mudanças Climáticas Para A Consolidação De Uma Economia De Baixa Emissão De Carbono Na Agricultura : Plano ABC (Agricultura De Baixa Emissão De Carbono) / Ministério da Agricultura, Pecuária e Abastecimento, Ministério do Desenvolvimento Agrário, coordenação da Casa Civil da Presidência da República. - Brasília : MAPA/ACS, 2012. 173 p. Disponível em: http://www.agricultura.gov.br/assuntos/sustentabilidade/planoabc/arquivo-publicacoes-plano-abc/download.pdf

BROWNSORT, P. A. Biomass Pyrolysis Processes: Review Of Scope, Control And Variability. Biomass, p. 38, 2009. Disponível em: https://www.biochar.ac.uk/download.php?id=14

BUEKENS, A.; HUANG, H. Comparative Evaluation Of Techniques For Controlling The Formation And Emission Of Chlorinated Dioxins/Furans In Municipal Waste Incineration. Journal of Hazardous Materials, v. 62, n. 1, p. 1-33, 1998. Disponível em: https://www.researchgate.net/profile/Alfons Buekens/publication/223841104 C omparati-

ve evaluation of techniques for controlling the formation and emission of chlorina-

te dioxinsfurans in municipal waste incineration/links/576cea9608aec1ce8e1 e90e1/Comparative-evaluation-of-techniques-for-controlling-the-formation-andemission-of-chlorinate-dioxins-furans-in-municipal-waste-incineration.pdf

BUNDHOO, Z. M. A.; MAUTHOOR, S.; MOHEE, R. Potential Of Biogas Production From Biomass And Waste Materials In The Small Island Developing State Of Mauritius. Renewable and Sustainable Energy Reviews, v. 56, p. 1087-1100, $2016 . \quad$ Disponível em: http://www.sciencedirect.com/science/article/pii/S1364032115014094 
BYUN, Y. et al. Demonstration Of Thermal Plasma Gasification/Vitrification For Municipal Solid Waste Treatment. Environmental science \& technology, v. 44, n. $17, \quad$ p. $6680-6684,2010$ Disponivel em: https://www.researchgate.net/publication/45459972 Demonstration of Thermal Plasma GasificationVitrification for Municipal Solid Waste Treatment

CAMPOS, Heliana Kátia Tavares. Renda E Evolução Da Geração Per Capita De Resíduos Sólidos No Brasil. Engenharia Sanitaria e Ambiental, [s.I.], v. 17, n. 2 , p.171-180, jun. 2012. FapUNIFESP (SciELO). http://dx.doi.org/10.1590/s1413-41522012000200006

CALIJURI, Maria do Carmo; CUNHA, Davi Gasparini Fernandes (Org.). Engenharia Ambiental: Conceitos, Tecnologia E Gestão. São Paulo: Elsevier Editora Ltda, 2013. 832 p.

CAMPOS, Luís Francisco. Desfluoretação Parcial Das Águas De Poços: Uma Aplicação Do Método De Análise Hierárquica (MAH). 2005. 116 f. Dissertação (Mestrado) - Curso de Mestrado em Saúde Pública, Programa de Pósgraduação da Escola Nacional de Saúde Pública da Fundação Oswaldo Cruz, Fundação Oswaldo Cruz, Rio de Janeiro - Rj, 2005. Disponível em: http://www.arca.fiocruz.br/handle/icict/5230. Acesso em: 17 maio 2016.

CANELLAS, L. P. et al. Avaliação de características dos ácidos húmicos de resíduos de origem urbana: II. métodos termodegradativos (pirólise acoplada à cromatografia gasosa / espectrometria de massa). Revista Brasileira de Ciência do Solo, [s.l.], v. 24, n. 4, p.751-757, dez. 2000. FapUNIFESP (SciELO). http://dx.doi.org/10.1590/s0100-06832000000400007

CASTANHO, Diego Solak; ARRUDA, Heder Jobbins de. Biodigestores. In: VI SEMANA DE TECNOLOGIA EM ALIMENTOS, 2008, Paraná. VI Semana de Tecnologia em Alimentos Resumo. Ponta Grossa: Universidade Tecnológica Federal do Paraná - Utfpr, 2008. p. 1 - 7. Disponível em: https://www.agencia.cnptia.embrapa.br/Repositorio/chines1 000g7gph0mm02w x5ok0wtedt3a5rn9mk.pdf. Acesso em: 24 mar. 2016. 
CENBIO - CENTRO NACIONAL DE REFERÊNCIA EM BIOMASSA. Comparação Entre Tecnologias De Gaseificação De Biomassa Existentes No Brasil E No Exterior E Formação De Recursos Humanos Na Região Norte: Estado Da Arte Da Gaseificação. 2002. Disponível em: http://cenbio.iee.usp.br/download/publicacoes/Estado da Arte.pdf. Acesso em: 18 abr.2011.

CHEN, Y. et al. Influence Of The Interaction On Nox Emission During CoCombustion Of Combustible Solid Waste Components. Journal of the Energy Institute, v. 89, n. 3, p. 313-324, 2015.

CONAMA. Resolução № 001, De 23 De Janeiro De 1986. Dispõe Sobre Critérios Básicos E Diretrizes Gerais Para A Avaliação De Impacto Ambiental. RESOLUÇÃO CONAMA № 001 . Disponível em: http://www.mma.gov.br/port/conama/legiabre.cfm?codlegi=23 . Acesso em: 05 ago. 2015.

CONAMA. Resolução № 316, De 29 De Outubro De 2002. Dispõe Sobre Procedimentos E Critérios Para O Funcionamento De Sistemas De Tratamento Térmico De Resíduos. RESOLUÇÃO CONAMA № 316. Disponível em: http://www.mma.gov.br/port/conama/legiabre.cfm?codlegi=338 . Acesso em: 05 ago. 2015.

CONAMA. Resolução № 382, De 26 De Dezembro De 2006. Estabelece Os Limites Máximos De Emissão De Poluentes Atmosféricos Para Fontes Fixas. RESOLUÇÃO CONAMA № 382 . Disponível em: http://www.mma.gov.br/port/conama/legiabre.cfm?codlegi=520 . Acesso em: 07 ago. 2015.

CONAMA. Resolução № 436, De 22 De Dezembro De 2011. Estabelece Os Limites Máximos De Emissão De Poluentes Atmosféricos Para Fontes Fixas Instaladas Ou Com Pedido De Licença De Instalação Anteriores A 02 De Janei- 
ro De 2007. Resolução Conama 436. Disponível em: http://www.mma.gov.br/port/conama/legiabre.cfm?codlegi=660

COSTA, Helder Gomes. Introdução Ao Método De Análise Hierárquica: Análise Multicritério No Auxílio À Decisão. Niterói: Uff, 2002. 122 p. Disponível em: http://www.din.uem.br/sbpo/sbpo2004/pdf/arq0279.pdf

COSTA, Helder Gomes; MOLL, Roberto Nunes. Employment Of The Analytic Hierarchy Process (AHP) In The Selection Of Sugar-Cane Varieties To Cultivate. Gestão \& Produção, v. 6, n. 3, p. 243-256, 1999.

DA SILVA, Andresa Lourenço. Breve Discussão Sobre O Conceito De Cidade Média. Geoingá: Revista do Programa de Pós-Graduação em Geografia, v. 5, n. 1, p. 58-76, 2013.

DETROIT STOKER COMPANY. Mass Burning. 2012. Disponível em: http://www.detroitstoker.com/main/detroit-stokers-reciprograte. Acesso em: 17 ago. 2016.

DODGE, Ed. Plasma-Gasification Of Waste. Cornel University, 2008. Disponível em: http://www.edwardtdodge.com/wp-content/uploads/2013/10/PlasmaGasification-of-Waste Dodge.pdf

DURIĆ, S. N. et al. Experimental Investigation Of Pyrolysis Process Of Agricultural Biomass Mixture. Periodica Polytechnica: Chemical Engineering, v. 58, n. 2, p. 141-147, 2014.

DUTRA, C. C.; FOGLIATTO, F. S. Operacionalização Do Processo Analítico Hierárquico Usando Matrizes Incompletas De Comparações Pareadas. In: Anais do XXXIX Simpósio Brasileiro de Pesquisa Operacional, Fortaleza. 2007. Disponível em: http://www.producao.ufrgs.br/arquivos/disciplinas/83 7 artigo operacionalizaca o do processo analitico hierarquico usando matrizes incompletas de comp aracoes pareadas.pdf 
EBNER, Jacqueline $\mathrm{H}$. et al. Anaerobic Co-Digestion Of Commercial Food Waste And Dairy Manure: Characterizing Biochemical Parameters And Synergistic Effects. Waste Management, [s.I.], v. 52, p.286-294, jun. 2016. Elsevier BV. http://dx.doi.org/10.1016/j.wasman.2016.03.046.

EIGENHEER, E. A História Do Lixo: A Limpeza Urbana Através Dos Tempos, Rio de Janeiro: Editora Campus, 2009. Disponível em: http://www.lixoeeducacao.uerj.br/imagens/pdf/ahistoriadolixo.pdf

EUROPEAN COMMITTEE FOR STANDARDIZATION. 15359: Solid Recovered Fuels - Specifications And Classes. Brussels: Cen, 2011. Disponível em: https://standards.cen.eu/dyn/www/f?p=204:110:0:.::FSP PROJECT,FSP ORG ID:28975,407430\&cs=11F595078DCD7B8535BD0EB30EBD4F625. Acesso em: 04 jan. 2017.

FEAM (MG). Fundação Estadual do Meio Ambiente (Org.). Estudo Do Estado Da Arte E Análise De Viabilidade Técnica, Econômica E Ambiental Da Implantação De Uma Usina De Tratamento Térmico De Resíduos Sólidos Urbanos Com Geração De Energia Elétrica No Estado De Minas Gerais. 2. ed. Belo Horizonte: Fundação Estadual do Meio Ambiente, 2010. P.174. Disponível em: http://www.feam.br/images/stories/fean/relatorio\%201\%20\%20estado\%20da\%2 0arte\%20do\%20tratamento\%20termico.pdf

FEAM (MG). Fundação Estadual do Meio Ambiente. Secretaria de Estado do Meio Ambiente e Desenvolvimento Sustentável. Aproveitamento Energético De Resíduos Sólidos Urbanos: Guia De Orientações Para Governos Municipais De Minas Gerais. Belo Horizonte: Secretaria de Estado do Meio Ambiente e Desenvolvimento Sustentável, 2012. 163 p. Disponível em: http://www.em.ufop.br/ceamb/petamb/cariboost files/aproveitamento 20 energ c3 a9tico.pdf. Acesso em: 17 ago. 2016. 
FUNASA (Brasilia - Df). Ministério da Saúde. Saneamento Para Promoção Da Saúde. Disponível em: http://www.funasa.gov.br/site/engenharia-de-saudepublica-2/saneamento-para-promocao-da-saude. Acesso em: 17 abr. 2017.

FUNASA (Brasilia - Df). Ministério da Saúde. Resíduos Sólidos. Disponível em: http://www.funasa.gov.br/site/engenharia-de-saude-publica-2/residuos-solidos. Acesso em: 17 abr. 2017.

FUNASA. Resíduos Sólidos e a Saúde da Comunidade: Informações Técnicas sobre a Interrelação Saúde, Meio Ambiente e Resíduos Sólidos. Brasília: Funasa, 2013. Disponível em: http://www.funasa.gov.br/site/wpcontent/files $\mathrm{mf} / \mathrm{cart}$ res sol 2.pdf. Acesso em: $12 \mathrm{dez} .2016$.

FUNTOWICZ, S. e RAVETZ, J.: 'Ciência pós-normal e comunidades ampliadas de pares face aos desafios ambientais'. História, Ciências, Saúde - Mangui$\begin{array}{llll}\text { nhos, } & \text { IV(2): } & \text { 219-230 jul.-out. } & \end{array}$ http://www.scielo.br/pdf/hcsm/v4n2/v4n2a01.pdf

GALLARDO, Antonio et al. Analysis Of Refuse-Derived Fuel From The Municipal Solid Waste Reject Fraction And Its Compliance With Quality Standards. Journal of Cleaner Production, v. 83, p. 118-125, 2014. Dicponivel em: http://repositori.uji.es/xmlui/bitstream/handle/10234/123186/JCP REPOSITORI \%20UJl gallardo carlos.pdf?sequence $=1$

GODECKE, Marcos Vinicius; NAIME, Roberto Harb; FIGUEIREDO, João Alcione Sganderla. O Consumismo E A Geração De Resíduos Sólidos Urbanos No Brasil. Electronic Journal of Management, Education and Environmental Technology (REGET), v. 8, n. 8, p. 1700-1712, 2013. Disponível em: http://webresol.org/textos/6380-33840-2-pb-2.pdf

GOULART, Eduardo A.; MARIOTONI, Carlos A. and SANCHEZ, Caio G.. A utilização da gaseificação de pneus usados em leito fluidizado para a produção de energéticos.Polímeros [online]. 1999, vol.9, n.4 [cited 2017-09-25], pp.123128. Available from: $<$ http://www.scielo.br/scielo.php?script=sci_arttext\&pid=S0104- 
$14281999000400021 \&$ lng=en\&nrm=iso >.

ISSN

0104-

1428. http://dx.doi.org/10.1590/S0104-14281999000400021.

GOUVEIA, N. Resíduos Sólidos Urbanos: Impactos Socioambientais E Perspectiva De Manejo Sustentável Com Inclusão Social. Ciência \& Saúde Coletiva, v. $17, \quad$ n. 6 , p. 1503-1510, 2012. Disponível em: http://www.scielo.br/pdf/csc/v17n6/v17n6a14.pdf

GRANDZOL, John R. Improving The Faculty Selection Process In Higher Education: A Case For The Analytic Hierarchy Process. Bloomsburg University of Pennsylvania. IR Applications Volume 6, August 24, 2005. Dispopnível em: http://files.eric.ed.gov/fulltext/ED504373.pdf

GRELHA DETROIT RECIPROGRATE® PARA QUEIMA DE LIXO. Disponível em: http://www.detroitstoker.com/. Acesso em: 13 ago. 2016.

GUG, J. I.; CACCIOLA, D.; SOBKOWICZ, M. J. Processing And Properties Of A Solid Energy Fuel From Municipal Solid Waste (MSW) And Recycled Plastics. Waste Management, v. 35, p. 283-292, 2015.

HÉNAULT-ETHIER, L. et al. Dynamics Of Physicochemical Variables And Cultivable Bacteria In Vermicompost During Steady Food Waste Addition And Upon Feed Interruption. Compost Science \& Utilization, v. 24, n. 2, p. 117-135, 2016.

HERCULANO, Selene; PORTO, Marcelo Firpo; FREITAS, Carlos Machado de (Org.). QUALIDADE DE VIDA E RISCOS AMBIENTAIS. Niterói - Rj: Eduff, 2000. $334 \mathrm{p}$.

IBGE - Instituto Brasileiro de Geografia e Estatística. Perfil Dos Municípios Brasileiros 2015: Gestão Ambiental. 2015. Disponível em: http://www.ibge.gov.br/home/estatistica/economia/perfilmunic/2015/default xls. shtm. Acesso em: 13 ago. 2016 
IBGE - Instituto Brasileiro de Geografia e Estatística. Pesquisa Nacional de Saneamento Básico - 2008. Rio de Janeiro - Rj: IBGE, 2010. 219 p. Disponível em: http://biblioteca.ibge.gov.br/visualizacao/livros/liv45351.pdf. Acesso em: 17 abr. 2017.

INCE, Orhan et al. Composting Practice For Sustainable Waste Management: A Case Study In Istanbul. Desalination and Water Treatment, v. 57, n. 31, p. 14473-14477, 2016.

Disponível em

https://www.researchgate.net/profile/Goezde Oezbayram/publication/27999512 3 Composting practice for sustainable waste management a case study i n Istanbul/links/55a232e608ae1c0e04641eaa/Composting-practice-forsustainable-waste-management-a-case-study-in-Istanbul.pdf

INGHELS, D.; DULLAERT, W.; BLOEMHOF, J. A Model For Improving Sustainable Green Waste Recovery. Resources, Conservation And Recycling, v. 110, p. 61-73, 2016.

IPEA - Instituto de Pesquisa Econômica Aplicada. CONSTANTINO CRONEMBERGER MENDES (Editor) (Brasil). Boletim Regional, Urbano E Ambiental. Brasília - DF: Editorar Multimídia, 2016. 134 p. (Jul.-dez. 2016). Disponível em:

http://www.ipea.gov.br/portal/images/stories/PDFs/boletim regional/160906 bru 15.pdf. Acesso em: 17 abr. 2017

ISMAIL, N.; ANI, F. N. A Review On Plasma Treatment For The Processing Of Solid Waste. Jurnal Teknologi, v. 72, n. 5, p. 41-49, 2015. Disponível em: http://www.jurnalteknologi.utm.my/index.php/jurnalteknologi/article/view/3938/28 $\underline{88}$

ITO, M. A. Patogenicidade De Fusarium Oxysporum F. Sp. Phaseoli, Adubação Nitrogenada E Produtividade De Feijão. p. 61, 2004. Disponivel em: http://www.teses.usp.br/teses/disponiveis/11/11136/tde-27042005141120/publico/marcio.pdf 
JACOBI, Pedro (Org.). Problemas Ambientais em São Paulo: Odesafio da coresponsabilidade e da gerência inovadora na crise. In: HERCULANO, Selene; PORTO, Marcelo Firpo; FREITAS, Carlos Machado de (Org.). Qualidade de Vida \& Riscos Ambientais. Niterói - Rj: Eduff, 2000. p. 247-264.

JIN, Y. et al. Life-Cycle Assessment Of Energy Consumption And Environmental Impact Of An Integrated Food Waste-Based Biogas Plant. Applied Energy, v. 151, n. July 2010, p. 227-236, 2015.

JUCÁ, José Fernando Thomé et al. Análise Das Diversas Tecnologias De Tratamento E Disposição Final De Resíduos Final Sólidos No Brasil, Europa, Estados Unidos E Japão. Recife: Ccs Gráfica e Editora, 2013. 188 p. - Jucá et al. (2013).

Disponível em:

http://www.abetre.org.br/biblioteca/publicacoes/publicacoesabetre/UFPEFADETecnologiasparaRSU2013.pdf

KHALID, Azeem et al. The Anaerobic Digestion Of Solid Organic Waste. Waste Management, [s.I.], v. 31, n. 8, p.1737-1744, ago. 2011. Elsevier BV. http://dx.doi.org/10.1016/j.wasman.2011.03.021.

KIGOZI, R.; ABOYADE, A. O.; MUZENDA, E. Technology Selection Of Biogas Digesters For OFMSW Via Multi-Criteria Decision Analysis. v. II, 2014.

KIGOZI, R.; ABOYADE, A.; MUZENDA, E.. Biogas Production Using The Organic Fraction Of Municipal Solid Waste. Journal Of Research In Chemical, Metallurgical And Civil Engg. Johannesburg, p. 107-114. mar. 2014. Disponível em: http://iieng.org/images/proceedings pdf/8652E1113563.pdf. Acesso em: 24 mar. 2016.

LAGO, Rochel Montero et al. Pirólise de resíduos de borrachas do setor de mineração para a produção de combustíveis: estudos em escala piloto. Polímeros, [s.l.], v. 27, n. , p.42-47, 2017. FapUNIFESP (SciELO). http://dx.doi.org/10.1590/0104-1428.2089. 
LANZA, Vera Cristina Vaz; CARVALHO, AL de. Orientações Básicas Para A Operação De Aterro Sanitário. Fundação Estadual do Meio Ambiente-Belo Horizonte, FEAM, 2006.2 Disponível em: http://www.feam.br/images/stories/arquivos/Cartilha\%20Aterro2.pdf

LAVELLE P, Martin A (1992) Small-Scale And Large-Scale Effects Of Endogeic Earthworms On Soil Organic Matter Dynamics In Soils Of The Humid Tropics. Soil Biol Biochem 12:1491-1498. Disponível em:

http://horizon.documentation.ird.fr/exldoc/pleins textes/pleins textes 6/b fdi 33-34/38608.pdf

LI, Y. et al. Land Application Of Compost And Other Wastes (By-Products) In Florida: Regulations, Characteristics, Benefits, And Concerns. HortTechnology, v. 20, n. 1, p. 41-51, 2010. Disponível em: https://www.sfwmd.gov/sites/default/files/documents/2008 bmp workshop land application compost.pdf

LI, Yebo; PARK, Stephen Y.; ZHU, Jiying. Solid-State Anaerobic Digestion For Methane Production From Organic Waste. Renewable And Sustainable Energy Reviews, [s.I.], v. 15, n. 1, p.821-826, jan. 2011. Elsevier BV. http://dx.doi.org/10.1016/j.rser.2010.07.042.

LIMA, J. D. DE et al. Uso De Modelos De Apoio A Decisão Para Analise De Alternativas Tecnológicas De Tratamento De Resíduos Sólidos Urbanos $\mathrm{Na}$ Região Sul Do Brasil. Engenharia Sanitaria e Ambiental, v. 19, n. 1, p. 33-42, 2014. Disponível em: http://www.scielo.br/pdf/esa/v19n1/1413-4152-esa-19-0100033.pdf

LIMA JUNIOR, Roberto Guião de Souza et al. Avaliação de novas práticas de compostagem em pequena escala com aproveitamento energético. Engenharia Sanitaria e Ambiental, [s.I.], v. 22, n. 2, p.361-370, abr. 2017. FapUNIFESP (SciELO). http://dx.doi.org/10.1590/s1413-41522016159687. 
LOPES, E. J.; OKAMURA, L. A.; YAMAMOTO, C. I. Formation Of Dioxins And Furans During Municipal Solid Waste Gasification. Brazilian Journal of Chemical Engineering, v. 32, n. 1, p. 87-97, 2015. Disponível em: http://www.scielo.br/pdf/bjce/v32n1/0104-6632-bjce-32-1-0087.pdf

LUNA, EJA., SILVA JR., JB. Doenças Transmissíveis, Endemias, Epidemias E Pandemias. In FUNDAÇÃO OSWALDO CRUZ. A saúde no Brasil em 2030 prospecção estratégica do sistema de saúde brasileiro: população e perfil sanitário. Disponível em: http://static.scielo.org/scielobooks/z9374/pdf/noronha9788581100180.pdf. Acesso em: 12 dez. 2016. Rio de Janeiro: Fiocruz/lpea/Ministério da Saúde/Secretaria de Assuntos Estratégicos da Presidência da República, 2013. Vol. 2. pp. 123-176. ISBN 978-85-8110-016-6.

MANNARINO, Camille Ferreira; FERREIRA, João Alberto; GANDOLLA, Mauro. Contribuições Para A Evolução Do Gerenciamento De Resíduos Sólidos Urbanos No Brasil Com Base Na Experiência Européia. Engenharia Sanitaria e Ambiental, [s.I.], v. 21, n. 2, p.379-385, jun. 2016. FapUNIFESP (SciELO). http://dx.doi.org/10.1590/s1413-41522016146475.

MARCHEZETTI, Ana Lúcia; KAVISKI, Eloy; BRAGA, Maria Cristina Borga. Aplicação Do Método AHP Para A Hierarquização Das Alternativas De Tratamento De Resíduos Sólidos Domiciliares. Revista da Associação Nacional de Tecnologia do Ambiente Construído, Porto Alegre - Rs, v. 11, n. 2, p.173-187, jun. $2011 . \quad$ Trimestral. Disponível em: http://www.scielo.br/pdf/ac/v11n2/a12v11n2.pdf. Acesso em: 19 maio 2016.

MARINS, Cristiano Souza; SOUZA, Daniela de Oliveira; BARROS, Magno da Silva. O Uso Do Método De Análise Hierárquica (Ahp) Na Tomada De Decisões Gerenciais: Um Estudo De Caso. In: Simpósio Brasileiro De Pesquisa Operacional, 2009, Ba. Pesquisa Operacional na Gestão do Conhecimento. Porto Seguro: UNIFACS, 2009. p. 1778 - 1788. Disponível em:

http://www2.ic.uff.br/ emitacc/AMD/Artigo\%204.pdf. . Acesso em: 12 jun. 2017. 
MENEZES, Paulo Cezar Freire. Sistemas Lógicos Paraconsistentes Aplicados aos Modelos Hierárquicos para Tomadas de Decisão: Estudo Realizado em Gestão de Projetos. 2015. 102 f. Dissertação (Mestrado) - Curso de Programa de Pós-graduação em Engenharia Mecânica Mestrado em Engenharia Mecânica, Engenharia, Universidade Santa Cecília, Santos/SP, 2015. Disponível em: https://unisanta.br/arquivos/mestrado/mecanica/dissertacoes/Dissertacao Paul o.pdf. Acesso em: 10 jul. 2017.

MCKAY, G. Dioxin Characterisation, Formation And Minimisation During Municipal Solid Waste (MSW) Incineration: Review. Chemical Engineering Journal, v. 86, n. 3, p. 343-368, 2002. Disponível em: http://www.sciencedirect.com/science/article/pii/S1385894701002285

MINISTÉRIO DA SAÚDE. Portaria № 2.446, De 13 De Novembro De 2014. Redefine A Política Nacional De Promoção Da Saúde (PNPS). Redefinição Da Política Nacional De Promoção Da Saúde. Disponível em: http://bvsms.saude.gov.br/bvs/saudelegis/gm/2014/prt2446 1111 2014.html. Acesso em: 05 abr. 2017.

MORGADO, T. C.; FERREIRA, O. M. Incineração De Resíduos Sólidos Urbanos, Aproveitamento Na Co-Geração De Energia: Estudo Para A Região Metropolitana De Goiânia. p. 1-18, 2006.

MUTER, O. et al. Potato Pulp As A Composting Substrate. Zemdirbyste, v. 101, n. 1, p. 57-66, 2014.

NITHIKUL, J. Potential Of Refuse Derived Fuel Production. Evaluation, v. Master of, n. December, p. 2005-2008, 2007.

OFICIAL, J. et al. Directiva 1999/31/CE. Jornal Oficial das Comunidades Europeias, v. 182, n. 10, p. 1-19, 1999. Disponível em: http://eurlex.europa.eu/legal-content/PT/TXT/PDF/?uri=CELEX:31999L0031\&from=EN 
OLIE, K.; VERMEULEN, P. L.; HUTZINGER, O. Chlorodibenzo-P-Dioxins And Chlorodibenzofurans Are Trace Components Of Fly Ash And Flue Gas Of Some Municipal Incinerators In The Netherlands. Chemosphere, v. 6, n. 8, p. 455459, 1977.

OLIVER, A. P. M.; et al. Manual De Treinamento Em Biodigestão. 2. ed. São Paulo: Winrock International Brasil, 2008. 23 p.

OLIVEIRA, Marcelo. Combustão e Combustíveis. 2015. Disponível em: http://pt.slideshare.net/HighProfileEngenharia/2-

quimicatecnologicaprodutosdacombustaeo. Acesso em: 13 ago. 2016.

OVIEDO-OCAÑA, R. et al. Effect Of Adding Bulking Materials Over The Composting Process Of Municipal Solid Biowastes. Chilean journal of agricultural research, v. 75, n. 4, p. 472-480, 2015.

PAIVA, Valeria, Andreia Mingroni Besteiro Giovani; BUENO, Miucciato Jomar. A Utilização Do Método AHP Para Traçar, Como Ferramenta Para O Auxilio A Decisão De Um Candidato, A Escolha De Um Curso De Engenharia. Disponivel em: http://let.aedb.br/seget/artigos09/226 Artigo - AHP Engenharia.pdf

PAN, leshita; DAM, Bomba; SEN, S. K.. Composting Of Common Organic Wastes Using Microbial Inoculants. 3 Biotech, [s.I.], v. 2, n. 2, p.127-134, 17 nov. 2011. Springer Nature. http://dx.doi.org/10.1007/s13205-011-0033-5.

PATHMA, J.; SAKTHIVEL, N. Microbial Diversity Of Vermicompost Bacteria That Exhibit Useful Agricultural Traits And Waste Management Potential. SpringerPlus, v. 1, n. 1, p. 26, 2012.

PEREIRA, Rodrigo Araújo; BIANCHINI, David. Aplicação do Método AHP na Tomada de Decisão Para a Redução dos Níveis de Ação Legal em Telecomunicações. Revista Brasileira de Marketing [en linea] 2013, 12 (OctubreDiciembre): Disponível em: http://www.redalyc.org/articulo.oa?id=471747654008. 
PERELLES, D. H.; MEDEIROS, M. F.; GARCEZ, M. R.. Aplicação Da Análise Hierárquica Como Ferramenta De Tomada De Decisão Para Escolha Do Compósito De Reforço Com Polímeros Reforçados Com Fibras. Revista Alconpat, [s.I.], v. 3, n. 3, p.164-176, 30 set. 2013. Revista ALCONPAT. http://dx.doi.org/10.21041/ra.v3i3.52.

PORTO, M.f. de Souza; FREITAS, C.m. de. Vulnerability and industrial hazards in industrializing countries: an integrative approach. Futures, [s.I.], v. 35, n. 7, p.717-736, set. 2003. Elsevier BV. http://dx.doi.org/10.1016/s00163287(03)00024-7.

PUYUELO, Belén et al. Comparison Of Compostable Bags And Aerated Bins With Conventional Storage Systems To Collect The Organic Fraction Of Municipal Solid Waste From Homes: A Catalonia Case Study. Waste Management, [s.l.], v. 33, n. 6, p.1381-1389, jun. 2013. Elsevier BV. http://dx.doi.org/10.1016/j.wasman.2013.02.015.

RADA, E. C.; RAGAZZI, M. RDF/SRF Evolution In The MSW Sector: Coexistence Of BMT And Selective Collection. International Journal of Sustainable Development and Planning, v. 10, n. 1, p. 109-119, 2015.

RAO, M. Bioenergy Conversion Studies Of Organic Fraction Of MSW: Kinetic Studies And Gas Yield - Organic Loading Relationships For Process Optimisation. Bioresource Technology, [s.I.], v. 95, n. 2, p.173-185, nov. 2004. Elsevier BV. http://dx.doi.org/10.1016/j.biortech.2004.02.013. Disponível em: http://api.elsevier.com/content/article/PII:S0960-8524(04)00053-

7?httpAccept=text/xml. Acesso em: 24 mar. 2016.

RIBEIRO, Deyvid da Silva. Determinação Das Dimensões De Um Biodigestor Em Função Da Proporção Gás/Fase Líquida. Holos, [s.I.], v. 1, p.49-56, 9 mar. 2011. Instituto Federal de Educação, Ciência e Tecnologia do Rio Grande do Norte (IFRN). http://dx.doi.org/10.15628/holos.2011.269. Disponível em: 
http://www2.ifrn.edu.br/ojs/index.php/HOLOS/article/view/269/418. Acesso em: 28 mar. 2016.

RICHARD, T. L. Municipal Solid Waste Composting: Physical Processing. Cornell University, p. 1-7, 1976.

RODRIGUES, André. O Papel Dos Microfungos Associados Aos Jardins Das Formigas Attini (Hymenoptera: Formicidae). 2009. 148 f. Tese (doutorado) Universidade Estadual Paulista, Instituto de Biociências de Rio Claro, 2009. Disponível em: http://hdl.handle.net/11449/103936.

RODRIGUES, Rodolfo; MARCILIO, Nilson Romeu; SECCHI, Argimiro Resende. Modelagem E Simulação De Um Gaseificador Em Leito Fixo Para O Tratamento Térmico De Resíduos Sólidos Da Indústria Calçadista. 2008. 171 f. Tese (Doutorado) - Curso de Engenharia, Programa de Pós-graduação em Engenharia Química, Universidade Federal do Rio Grande do Sul. Escola de Engenharia. Programa de Pós-graduação em Engenharia Química, Porto Alegre, Rs, 2008. Disponível em: http://hdl.handle.net/10183/15948. Acesso em: 13 ago. 2016.

ROLLINSON, A. N.; KARMAKAR, M. K. On The Reactivity Of Various Biomass Species With $\mathrm{CO}_{2}$ Using A Standardised Methodology For Fixed-Bed Gasification. Chemical Engineering Science, v. 128, n. x, p. 82-91, 2015.

SAATY, Thomas L. A Scaling Method For Priorities In Hierarchical Structures. Journal Of Mathematical Psychology, [s.I.], v. 15, n. 3, p.234-281, jun. 1977. Elsevier BV. http://dx.doi.org/10.1016/0022-2496(77)90033-5.

SAATY, Thomas L. Decision Making With The Analytic Hierarchy Process. International journal of services sciences, v. 1, n. 1, p. 83-98, 2008.

SALOMON, Valério P.; MONTEVECHI, José Arnaldo B.; PAMPLONA, Edson O. Justificativas Para Aplicação Do Método De Análise Hierárquica. In: Encontro Nacional De Engenharia De Produção, 19., 1999, RJ. Anais do Encontro 
Nacional de Engenharia de Produção ENEGEP e ICIEOM. Rio de Janeiro: ABEPRO, 1999. p. 1 - $17 . \quad$ Disponível em: http://www.abepro.org.br/biblioteca/ENEGEP1999 A0034.PDF.Acesso em: 10 out. 2016.

SAMSON, M.; AKINWALE, A.; EDISON, M. Process Simulation And Parametric Study Of A Biogas Upgrading Plant Using Gas Permeation Technique For Methane Enrichment. v. 19, n. 2, p. 18-31, 2014.

SCANO, Efisio Antonio et al. Biogas From Anaerobic Digestion Of Fruit And Vegetable Wastes: Experimental Results On Pilot-Scale And Preliminary Performance Evaluation Of A Full-Scale Power Plant. Energy Conversion And Management, [s.I.], v. 77, p.22-30, jan. 2014. Elsevier BV. http://dx.doi.org/10.1016/j.enconman.2013.09.004.

SCHMIDT, Marcio Augusto Reolon; BARBOSA, Gustavo Rodrigues. Uso De Redes Neurais Artificiais Na Ponderação Inicial Da Técnica Ahp Em Análises De Vulnerabilidade De Bacias Hidrográficas. Boletim de Ciências Geodésicas, [s.l.], v. 22, n. 3, p.511-525, set. 2016. FapUNIFESP (SciELO). http://dx.doi.org/10.1590/s1982-21702016000300029.

SENA, Lunardo Alves de. Uma Aplicação De Análise De Decisão Com O Método AHP Processo De Hierarquia Analítica: Um Estudo Sobre Adoção De Sistema Eletrônico De Cobrança No Transporte Público Urbano. 2007.

SILVA, Maria das Graças e; ARAÚJO, Nailsa Maria Souza; SANTOS, Josiane Soares. "Consumo Consciente": O Ecocapitalismo Como Ideologia. Revista Katálysis, [s.l.], v. 15, n. 1, p.95-111, jun. 2012. FapUNIFESP (SciELO). http://dx.doi.org/10.1590/s1414-49802012000100010.

SILVA, D. M. R. Aplicação Do Método AHP Para Avaliação De Projetos Industriais. Dissertação Mestrado Programa de PósGraduação em Engenharia Industrial da PUC-Rio, p. 128, 2007. Disponível em: 
https://www.maxwell.vrac.puc-

rio.br/Busca etds.php?strSecao=resultado\&nrSeq=10385@1

SILVA, Harley; BARBIERI, Alisson Flávio; MONTE-MÓR, Roberto L.. Demografia Do Consumo Urbano: Um Estudo Sobre A Geração De Resíduos Sólidos Domiciliares No Município De Belo Horizonte. Rev. Bras. Estud. Popul., [s.I.], v. 29, n. 2, p.421-449, dez. 2012. FapUNIFESP (SciELO). http://dx.doi.org/10.1590/s0102-30982012000200012.

SILVA, José Francisco Guimarães O. R.; SILVA, Maíra Ferraz de Oliveira. Utilização De Biodigestores Para A Produção De Energia Alternativa, Biofertilizantes E Tratamento De Resíduos: Alternativas Econômicas E De Menor Impacto Ambiental Para A Pecuária. 2012. 20 f. TCC (Graduação) - Curso de Ciências Econômicas, Universidade Federal do Sudoeste da Bahia, Vitória da Conquista Ba, 2012. Disponível em: http://www.uesb.br/eventos/semana economia/2012/anais/a03.pdf. Acesso em: 25 mar. 2016.

SIMON, G. A.; LAMBERT, E. D. S. Seleção De Clones De Batata Resistentes À Pinta Preta E Tolerantes Ao Calor. v. 56, n. 1, p. 31-37, 2009.

SIQUEIRA, T. M. Oliveira de; ASSAD, Maria Leonor Ribeiro Casimiro Lopes. Compostagem De Resíduos Sólidos Urbanos No Estado De São Paulo (Brasil). Ambiente \& Sociedade, v. 18, n. 4, p. 243-264, 2015.

SIQUEIRA, Mônica Maria; MORAES, Maria Silvia de, Saúde coletiva, resíduos sólidos urbanos e os catadores de lixoCiência \& Saúde Coletiva [en linea] 2009, 14 (Diciembre-Sin mes) : [Fecha de consulta: 25 de septiembre de 2017] Disponible en: $\leq$ http://www.redalyc.org/articulo.oa?id=63012431016>ISSN 1413-8123

SNIS - Sistema Nacional de Informações sobre Saneamento. BRASIL. Ministério das Cidades. Diagnóstico do Manejo de Resíduos Sólidos Urbanos - 2015. Brasília

DF, 2017.

Disponível em: 
http://www.snis.gov.br/downloads/diagnosticos/rs/2015/DiagRS2015.zip. Acesso em: 17 abr. 2017.

SOUSA, Ana Cristina A. de; COSTA, Nilson do Rosário. Política De Saneamento Básico No Brasil: Discussão De Uma Trajetória. História, Ciências, Saúdemanguinhos, [s.I.], v. 23, n. 3, p.615-634, set. 2016. FapUNIFESP (SciELO). http://dx.doi.org/10.1590/s0104-59702016000300002.

SOUZA, O. et al. Biodegradação De Resíduos Lignocelulósicos Gerados Na Bananicultura E Sua Valorização Para A Produção De Biogás. Revista Brasileira de Engenharia Agrícola e Ambiental, v. 14, n. 4, p. 438-443, 2010.

SOUZA, Mayra Ferrari de. Tratamento de Resíduos Sólidos Urbanos com recuperação Energética por Meio de Tecnologia de Plasma: Estudo de Caso para a Região de Taubaté - SP. 2014. 40 f. Monografia (Especialização) - Curso de Gestão Ambiental e Negócios, Setor Energético, Universidade de São Paulo, São Paulo - Sp, 2014. Disponível

em:

http://200.144.182.130/iee/sites/default/files/Mayra\%20Ferrari\%20de\%20Souza.pdf.

Acesso em: 13 ago. 2017.

STASSEN, H.E., 1995. Small-Scale Biomass Gasifiers For Heat And Power: A Global Review, World Bank Technical Paper no 296. The World Bank, Washington DC, pp. 1-88

SUN, L. Z. et al. Development Of Plasma Technology For The Treatment Of Environmental Wastes. Applied Mechanics and Materials, v. 295-298, p. 18461849, 2013.

THIRZA, A. et al. Revista Brasileira de Ciências da Amazônia. Aproveitamento Da Fração Orgânica Dos Resíduos Sólidos Urbanos Para Produção De Composto Orgânico. n. 1, p. 15-28, [s.d.].

TORRES, Aline; PEDROSA, João Felipe; MOURA, Johnson Pontes de. Fundamentos De Implantação De Biodigestores Em Propriedades Rurais. 2012. 
Disponível em: http://www.revistaea.org/artigo.php?idartigo=1248. Acesso em: 25 mar. 2016.

UFPE - Universidade Federal de Pernambuco. Análise Das Diversas Tecnologias De Tratamento E Disposição Final De Resíduos Sólidos Urbanos No Brasil, Europa, Estados Unidos E Japão. Pesquisa Científica, BNDES FEP n. 02/2010. Jaboatão dos Guararapes, PE: Grupo de Resíduos Sólidos - UFPE, 2014. 184 p. Disponível em:

http://www.abetre.org.br/biblioteca/publicacoes/publicacoesabetre/UFPEFADETecnologiasparaRSU2013.pdf

UNI - ENTE NAZIONALE ITALIANO DI UNIFICAZIONE. 9903: Combustibili Solidi Non Minerali Ricavati Da Rifiuti (RDF) - Classificazione E Caratteristiche. Milano: Uni, 1997. Disponível em: http://store.uni.com/magento1.4.0.1/index.php/uni-9903-1-1997.html. Acesso em: 04 jan. 2017

URBAN, Rodrigo Custódio. Índice De Adequação Do Gerenciamento De Resíduos Sólidos Urbanos Como Ferramenta Para O Planejamento: Aplicação No Estado De São Paulo. Engenharia Sanitaria e Ambiental, [s.I.], v. 21, n. 2, p.367-377, jun. 2016. FapUNIFESP (SciELO). http://dx.doi.org/10.1590/s141341522016140543.

VAN DAEL, M. et al. A Techno-Economic Evaluation Of A Biomass Energy Conversion Park. Applied Energy, v. 104, p. 611-622, 2013. Disponível em: http://www.sciencedirect.com/science/article/pii/S0306261912008768

VERMA, Shefali. Anaerobic Digestion Of Biodegradable Organics In Municipal Solid Wastes. 2002. 56 f. Dissertação (Mestrado) - Curso de Earth Resources Engineering, Columbia University, New York, 2002. Disponível em: http://www.seas.columbia.edu/earth/wtert/sofos/Verma thesis.pdf.Acesso em: 24 mar. 2016.

Vidal-Martins, A.M.C.; Rossi Jr., O.D.; Rezende-Lago, N.C.. Microrganismos Heterotróficos Mesófilos E Bactérias Do Grupo Do Bacillus Cereus Em Leite 
Integral Submetido A Ultra Alta Temperatura. Arquivo Brasileiro de Medicina Veterinária e Zootecnia. Universidade Federal de Minas Gerais, Escola de Veterinária, v. $57, \quad$ n. $3, \quad$ p. 396-400, 2005. Disponível em: http://repositorio.unesp.br/bitstream/handle/11449/28570/S010209352005000300019. pdf? sequence $=1$ \&is Allowed $=y$.

VITAL, Marcos Henrique Figueiredo; PINTO, Marco Aurélio Cabral; INGOUVILLE, Martin. Estimativa De Investimentos Em Aterros Sanitários Para Atendimento De Metas Estabelecidas Pela Política Nacional De Resíduos Sólidos Entre 2015 E 2019. 2014. Disponível em: https://web.bndes.gov.br/bib/ispui/bitstream/1408/3041/1/Estimativa\%20de\%20i nvestimentos\%20em\%20aterros\%20sanitarios P.pdf

WANG, H. et al. Study Of The Application And Methods For The Comprehensive Treatment Of Municipal Solid Waste In Northeastern China. Renewable and Sustainable Energy Reviews, v. 52, p. 1881-1889, 2015. Disponível em: http:/www.sciencedirect.com/science/article/pii/S1364032115008989

WYNNE, B. Uncertainty and environmental learning 1, 2Reconceiving science and policy in the preventive paradigm. Global Environmental Change, [s.I.], v. 2, n. 2, p.111-127, jun. 1992. Elsevier BV. http://dx.doi.org/10.1016/09593780(92)90017-2.

YASAR, D.; CELIK, N.; SHARIT, J. Evaluation Of Advanced Thermal Solid Waste Management Technologies For Sustainability In Florida. v. 12, n. 1, p. 6378, 2016. Disponível em: http://paris.utdallas.edu/IJPE/Vol12/lssue01/pp.6378\%20Paper\%206\%20IJPE\%20637.15\%20Sharit\%20p.16.pdf

YASAR, D.; CELIK, N.; SHARIT, J. Evaluation Of Advanced Thermal Solid Waste Management Technologies For Sustainability In Florida. v. 12, n. 1, p. 6378, 2016. Disponível em: http://paris.utdallas.edu/IJPE/Vol12/lssue01/pp.6378\%20Paper\%206\%20|JPE\%20637.15\%20Sharit\%20p.16.pdf 
YOUNAN, Y.; VAN GOETHEM, M. W. M.; STEFANIDIS, G. D. A Particle Scale Model For Municipal Solid Waste And Refuse-Derived Fuels Pyrolysis. Computers and Chemical Engineering, v. 86, p. 148-159, 2016. Disponível em: http://www.sciencedirect.com/science/article/pii/S009813541500383X

ZAMBON, Antonio Carlos et al. Obsolescência Acelerada De Produtos Tecnológicos E Os Impactos Na Sustentabilidade Da Produção. Ram, Rev. Adm. Mackenzie, [s.I.], v. 16, n. 4, p.231-258, ago. 2015. FapUNIFESP (SciELO). http://dx.doi.org/10.1590/1678-69712015/administracao.v16n4p231-258. 


\section{GLOSSÁRIO}

Aterro sanitário - técnica de disposição do lixo, fundamentado em critérios de engenharia e normas operacionais específicas, que permite a confinação segura em termos de controle da poluição ambiental e proteção à saúde pública.

Aterro controlado - local utilizado para despejo do lixo coletado, em bruto, com cuidado de, após a jornada de trabalho, cobri-lo com uma camada de terra, sem causar danos ou riscos à saúde pública e a segurança, minimizando os impactos ambientais.

Lixão ou Vazadouro a céu aberto - disposição final do lixo pelo seu lançamento, em bruto, sobre o terreno sem qualquer cuidado ou técnica especial. Vazadouro em áreas alagadas - disposição final do lixo pelo seu lançamento, em bruto.

Resíduos Sólidos Urbanos (RSU) ou Resíduos Sólidos Municipais (RSM) são compostos por resíduos domiciliares: os originários de atividades domésticas em residências urbanas; e resíduos de limpeza urbana: os originários da varrição, limpeza de logradouros e vias públicas e outros serviços de limpeza urbana.

Fração Orgânica de Resíduos Sólidos Municipais - Parte putrescível que compõe os Resíduos Sólidos Municipais.

Destinação Final Ambientalmente Adequada - destinação de resíduos que inclui a reutilização, a reciclagem, a compostagem, a recuperação e o aproveitamento energético ou outras destinações admitidas pelos órgãos competentes do Sisnama (Sistema Nacional do Meio Ambiente), do SNVS (Sistema Nacional de Vigilância Sanitária) e do Suasa (Sistema Unificado de Atenção à Sanidade Agropecuária), entre elas a disposição final, observando normas operacionais específicas de modo a evitar danos ou riscos à saúde pública e à segurança e a minimizar os impactos ambientais adversos. 
Disposição Final Ambientalmente Adequada: distribuição ordenada de rejeitos em aterros, observando normas operacionais específicas de modo a evitar danos ou riscos à saúde pública e à segurança e a minimizar os impactos ambientais adversos.

Rejeitos - resíduos sólidos que, depois de esgotadas todas as possibilidades de tratamento e recuperação por processos tecnológicos disponíveis e economicamente viáveis, não apresentem outra possibilidade que não a disposição final ambientalmente adequada.

Responsabilidade Compartilhada pelo Ciclo de Vida dos Produtos: conjunto de atribuições individualizadas e encadeadas dos fabricantes, importadores, distribuidores e comerciantes, dos consumidores e dos titulares dos serviços públicos de limpeza urbana e de manejo dos resíduos sólidos, para minimizar o volume de resíduos sólidos e rejeitos gerados, bem como para reduzir os impactos causados à saúde humana e à qualidade ambiental decorrentes do ciclo de vida dos produtos, nos termos desta Lei. 


\section{APÊNDICE I}

\begin{tabular}{|c|c|c|c|c|c|c|c|c|c|}
\hline \multicolumn{2}{|c|}{ Tecnologias } & \multirow{2}{*}{$\begin{array}{c}\begin{array}{c}\text { Volume } \\
\text { Tratável } \\
\text { (ton/ano) }\end{array} \\
320.000\end{array}$} & \multirow{2}{*}{$\begin{array}{l}\begin{array}{l}\text { Requer pré- } \\
\text { tratamento }\end{array} \\
\text { sim (granula- } \\
\text { ção) } \\
\end{array}$} & \multirow{2}{*}{$\begin{array}{c}\begin{array}{c}\text { População } \\
\text { Atendida } \\
\text { (mil habi- } \\
\text { tantes) }\end{array} \\
\begin{array}{c}\text { acima de } \\
500\end{array} \\
\end{array}$} & \multirow{2}{*}{$\begin{array}{c}\begin{array}{c}\text { Custo } \\
\text { por } \\
\text { tonelada }\end{array} \\
\text { Baixo } \\
\end{array}$} & \multirow{2}{*}{$\begin{array}{c}\begin{array}{c}\text { Requer } \\
\text { segregação } \\
\text { dos RSU }\end{array} \\
\text { Sim } \\
\end{array}$} & \multirow{2}{*}{$\begin{array}{c}\text { Impactos Positivos } \\
\begin{array}{c}\text { Geração de fertilizan- } \\
\text { tes } \\
\text { Geração de biogás }\end{array}\end{array}$} & \multirow{2}{*}{$\begin{array}{l}\text { Impactos Negativos } \\
\begin{array}{l}\text { Necessidade de purifi- } \\
\text { cação do biogás }\end{array}\end{array}$} & \multirow{2}{*}{$\begin{array}{c}\text { Referência } \\
\text { BUNDHOO et al., } \\
2016 \\
\end{array}$} \\
\hline & Biodigestor & & & & & & & & \\
\hline \multirow{3}{*}{ Biológicas } & Co-digestão & 7.700 .000 & $\begin{array}{l}\text { sim (granula- } \\
\text { ção) }\end{array}$ & $\begin{array}{l}\text { acima de } \\
500\end{array}$ & Baixo & Sim & $\begin{array}{c}\text { Geração de fertilizan- } \\
\text { tes } \\
\text { Geração de biogás }\end{array}$ & $\begin{array}{l}\text { Necessidade de purifi- } \\
\text { cação do biogás }\end{array}$ & $\begin{array}{l}\text { Li, Park e Zhu, } 2011 \\
\text { Cocco et al., } 2014 \\
\text { Jin et al. } 2015\end{array}$ \\
\hline & Compostagem & 340.000 & $\begin{array}{l}\text { Aconselhável } \\
\text { (granulação) }\end{array}$ & $\begin{array}{c}\text { entre } \\
100.000 \text { e } \\
500.000\end{array}$ & Baixo & Sim & $\begin{array}{l}\text { Geração de fertilizante } \\
\text { de alta qualidade } \\
\text { Processo barato }\end{array}$ & $\begin{array}{l}\text { Requer revolvimento } \\
\text { (LEAs) ou Aeração } \\
\text { Trata pequenos volu- } \\
\text { mes por vez }\end{array}$ & $\begin{array}{c}\text { Siqueira e Assad } \\
(2016) \\
\text { Bidone e Povinelli } \\
(2010) \\
\text { HÉNAULT-ETHIER et } \\
\text { al.(2016) } \\
\text { Amaral et al, } 2015\end{array}$ \\
\hline & $\begin{array}{c}\text { Vermi- } \\
\text { compostagem }\end{array}$ & 340.000 & $\begin{array}{c}\operatorname{sim}(\text { granula- } \\
\text { ção) }\end{array}$ & $\begin{array}{l}\text { acima de } \\
\quad 500\end{array}$ & Baixo & Sim & $\begin{array}{l}\text { Geração de fertilizante } \\
\text { de alta qualidade } \\
\text { Processo barato } \\
\text { Destruição de patóge- } \\
\text { nos }\end{array}$ & $\begin{array}{l}\text { Requer revolvimento } \\
\text { (LEAs) ou Aeração } \\
\text { Trata pequenos volu- } \\
\text { mes por vez } \\
\text { Requer cuidado com } \\
\text { as minhocas }\end{array}$ & $\begin{array}{c}\text { HÉNAULT-ETHIER et } \\
\text { al.(2016) }\end{array}$ \\
\hline Térmicas & Incineração & 30.000 .000 & $\begin{array}{c}\text { não } \\
\text { (mass burn) }\end{array}$ & $\begin{array}{l}\text { acima de } \\
500\end{array}$ & Baixo & Não & $\begin{array}{l}\text { Redução expressiva } \\
\text { de volume de resíduos } \\
\text { em aterros (90-99\%) }\end{array}$ & $\begin{array}{c}\text { Emissões atmosféricas } \\
\text { de dioxinas, furanos e } \\
\text { mercúrio. }\end{array}$ & Gug et al, 2015 \\
\hline
\end{tabular}




\begin{tabular}{|c|c|c|c|c|c|c|c|c|}
\hline Pirólise & 230.000 & $\begin{array}{l}\text { sim (granu- } \\
\text { lação e } \\
\text { secagem) }\end{array}$ & até 500 & Médio & Sim & $\begin{array}{l}\text { Geração de Syngas } \\
\text { Geração de Bio- } \\
\text { óleos } \\
\text { Geração de Biochar }\end{array}$ & $\begin{array}{c}\text { Uso de equipamen- } \\
\text { tos caros } \\
\text { Exigencia de equipe } \\
\text { treinada para ma- } \\
\text { nuseios } \\
\text { Geração de Alca- } \\
\text { trão } \\
\text { Necessidade de } \\
\text { secagem previa do } \\
\text { material } \\
\text { Só trata matéria } \\
\text { orgânica }\end{array}$ & $\begin{array}{l}\text { Younan et al, } 2016 \\
\text { Chen et al, } 2015 \\
\text { Duric et al, } 2014\end{array}$ \\
\hline CDR & 230.000 & $\begin{array}{l}\operatorname{sim} \text { (granu- } \\
\text { lação) }\end{array}$ & $\begin{array}{c}\text { entre } \\
100.000 \mathrm{e} \\
500.000\end{array}$ & Médio & Sim & $\begin{array}{c}\text { Geração de energia } \\
\text { Reuso dos residuos } \\
\text { Redução de emis- } \\
\text { sões atmosféricas } \\
\text { Menor custo de } \\
\text { Logistica }\end{array}$ & $\begin{array}{c}\text { Alto consumo ener- } \\
\text { gético } \\
\text { Presença de con- } \\
\text { taminantes (Metais) } \\
\text { Processamento dos } \\
\text { residuos } \\
\text { Requer filtros para } \\
\text { emissões atmosféri- } \\
\text { cas (nos locais de } \\
\text { queima) }\end{array}$ & $\begin{array}{c}\text { Younan et al, } 2016 \\
\text { Gallardo et al (2014) } \\
\text { Juca et al (2013) } \\
\text { NITHIKUL (2007) }\end{array}$ \\
\hline Gaseificação & 230.000 & $\begin{array}{l}\text { sim (granu- } \\
\text { lação e } \\
\text { secagem) }\end{array}$ & $\begin{array}{c}\text { entre } \\
100.000 \mathrm{e} \\
500.000\end{array}$ & Médio & Sim & Geração de Syngas & $\begin{array}{l}\text { Uso de equipamen- } \\
\text { tos caros } \\
\text { Exigencia de equipe } \\
\text { treinada para ma- } \\
\text { nuseios } \\
\text { Geração de Alca- } \\
\text { trão } \\
\text { Necessidade de } \\
\text { secagem previa do } \\
\text { material } \\
\text { Só trata matéria } \\
\text { orgânica }\end{array}$ & $\begin{array}{c}\text { Andrade (2007) } \\
\text { Rollinson e Karma- } \\
\text { ker,(2015) } \\
\text { Arena (2012) } \\
\text { Chen et al, 2015 }\end{array}$ \\
\hline
\end{tabular}




\begin{tabular}{|c|c|c|c|c|c|c|c|c|}
\hline Plasma & 260.000 & $\begin{array}{l}\text { sim (granu- } \\
\text { lação) }\end{array}$ & $\underset{500}{\operatorname{acima} \text { de }}$ & Alto & Sim & $\begin{array}{l}\text { Geração de Syngas } \\
\text { Redução expressiva } \\
\text { do volume dos RSU } \\
\text { Destruição de subs- } \\
\text { tancias tóxicas } \\
\text { Fixação de metais } \\
\text { Vitrificação de silica- } \\
\text { tos }\end{array}$ & $\begin{array}{l}\text { Alto custo de im- } \\
\text { plantação } \\
\text { Alto consumo ener- } \\
\text { gético }\end{array}$ & $\begin{array}{l}\text { BYUN, Y. et } \\
\text { al.(2010) } \\
\text { Dodge (2008) }\end{array}$ \\
\hline Lixão & Sem limite & & Sem limite & $\begin{array}{l}\text { Sem } \\
\text { custo }\end{array}$ & Não & & $\begin{array}{c}\text { Emissões atmosfé- } \\
\text { ricas } \\
\text { chorume } \\
\text { contaminação de } \\
\text { solo, águas superfi- } \\
\text { ciais e subterrâneas } \\
\text { Necessidade de } \\
\text { monitoramento } \\
\text { constante } \\
\text { llegal }\end{array}$ & \\
\hline Aterro Controlado & & & & & Não & & $\begin{array}{c}\text { Emissões atmosfé- } \\
\text { ricas } \\
\text { chorume } \\
\text { contaminação de } \\
\text { solo, águas superfi- } \\
\text { ciais e subterrâneas } \\
\text { Necessidade de } \\
\text { monitoramento } \\
\text { constante }\end{array}$ & \\
\hline Aterros Sanitário & & & & & Deveria & $\begin{array}{l}\text { Recebe Grandes } \\
\text { Volumes de resí- } \\
\text { duos. }\end{array}$ & $\begin{array}{l}\text { Requer manutenção } \\
\text { durante o uso e } \\
\text { após o fim das ativi- } \\
\text { dades (passivo } \\
\text { ambiental) }\end{array}$ & \\
\hline
\end{tabular}




\section{APÊNDICE II}

AVALIAÇÃo COMPARATIVA de CUSTOS

Nome:

\section{INSTRUÇÕES}

Você deve avaliar, baseado na sua percepção, três tecnologias de gestão de resíduos sólidos (aterros sanitários; incineração; e biodigestor anaeróbio) para serem utilizadas em um município médio (200.000 habitantes) em relação a três tipos custos (Custo de Logística, Custo de Implantação e Custo de Impa ctos). Essas tecnologias serão sempre comparadas duas-a-duas em relação a cada um dos tipos de custo separadamente, i.e., em cada avaliação, você deve comparar duas tecnologias de gestão de resíduos em relação a APENAS um dos custos (Logística, Implantação ou Impactos) de cadas vez.

Nas suas avaliações comparativas das três diferentes tecnologias (aterros sanitários; incineração; e biodigestor anaeróbio), baseada em cada um dos custos (Custo de Logística, Custo de Implantação e Custo de Impactos) analisados individualmente, considere que uma tecnologia seja SUPERIOR a outra com relação a um determinado custo, quando apresentar CUSTOS respectivamente MENORES.

Nas suas avaliações, será importante você determinar o grau de superioridade (equivalente; levemente superior; moderadamente superior; expressivamente superior; ou absolutamente superior) de uma tecnologia em relação a outra tecnologia para cada custo considerado (Custo de Logística, Custo de Implantação e Custo de Impactos).

Ao final de cada avaliação de CUSTO, você deve atribuir uma nota geral para cada tecnologia em rel ação a um determinado custo (Logística, Implantação ou Impactos).

a) Compare as tecnologias apresentadas (Coleta de Resíduos sem segregação \& Coleta de Resíduos com segregação) em relação ao CUSTO DE LOGÍSTICA. Nesta etapa, somente leve em conta os custos de logística. Não leve em conta outros custos.

Para efeito de sua comparação, considere: CUSTO DE LOGÍSTICA como sendo composto por todos os custos diretos e indiretos relativos à coleta, ao transporte e ao armazenamento visando o tratamento, a destinação ou a disposição final dos resíduos sólidos urbanos.

1. Coleta de resíduos sem segregação (coleta de resíduos indiferenciados)

2. Coleta de resíduos com segregação (coleta de resíduos diferenciados)

\begin{tabular}{|c|c|c|c|c|c|c|c|c|}
\hline 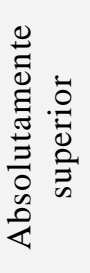 & 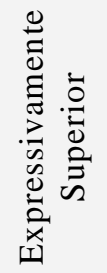 & 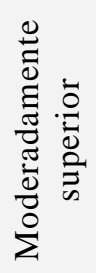 & 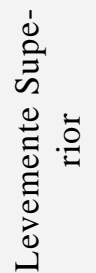 & 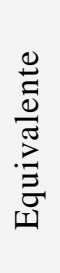 & 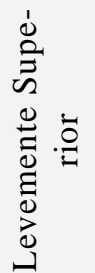 & 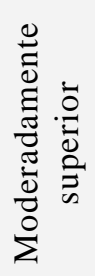 & 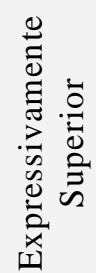 & 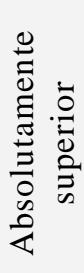 \\
\hline & & & & & & & & \\
\hline
\end{tabular}

Considerando o Custo de Logística dos 2 tipos de coletas, atribua uma nota entre 1(um) e 10 (dez). Uma nota 1 (um) indica um custo elevadíssimo e uma nota 10 (dez) indica um custo baixíssimo.

Custo da coleta de resíduos sem segregação:

Custo da coleta de resíduos com segregação:

Nota:

Nota: 
b) Compare as tecnologias apresentadas em relação ao CUSTO DE IMPLANTAÇÃO. Somente leve em conta os custos da tecnologia, não considere outros custos.

Para efeito de sua análise, considere: CUSTO DE IMPLANTAÇÃO como sendo composto por todos os custos diretos e indiretos relativos ao projeto, à construção, à operação, ao controle, à man utenção e ao descomissoamento das instalações e dos processos necessários para utilização de determinada tecnologia (Aterro Sanitário; Tratamento Térmico - Incinerador; e Tratamento Biológico / Térmico - Biodigestor Anaeróbio) visando o tratamento, a destinação ou a disposição final dos resíduos sólidos urbanos.

\begin{tabular}{|c|c|c|c|c|c|c|c|c|}
\hline \multicolumn{5}{|c|}{ 1. Aterros sanitários } & \multicolumn{4}{|c|}{$\begin{array}{c}\text { Tratamento biológico e térmico (Biodiges- } \\
\text { tor Anaeróbio) }\end{array}$} \\
\hline 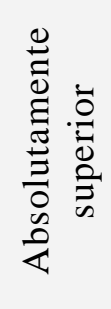 & 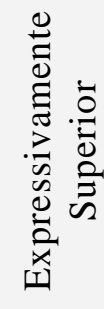 & 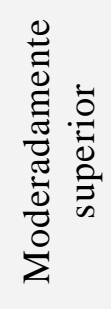 & 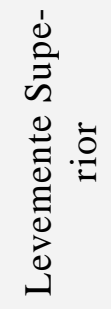 & $\begin{array}{l}\stackrel{0}{\Xi} \\
\frac{0}{\pi} \\
\stackrel{\Xi}{\Xi} \\
\underset{I}{J}\end{array}$ & 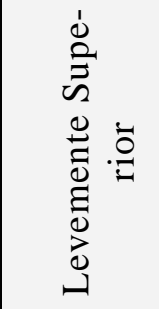 & 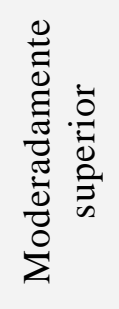 & 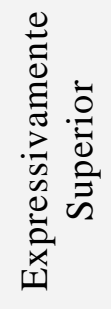 & 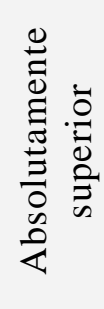 \\
\hline \multicolumn{5}{|c|}{ 3. Aterros sanitários } & \multicolumn{4}{|c|}{ 4. Tratamento térmico (Incineração) } \\
\hline 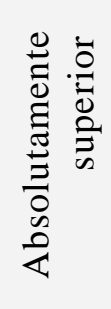 & 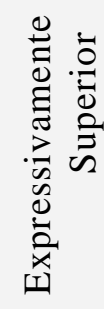 & 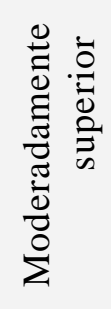 & 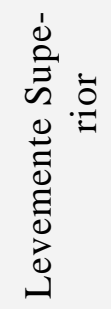 & $\begin{array}{l}\stackrel{0}{\Xi} \\
\frac{0}{\tilde{J}} \\
\stackrel{\Xi}{\Xi} \\
\stackrel{\Xi}{\Xi}\end{array}$ & 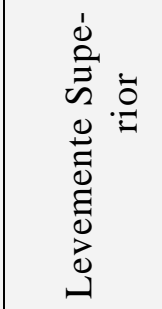 & 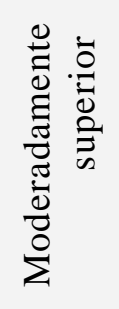 & 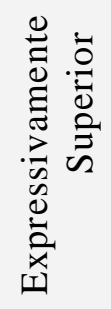 & 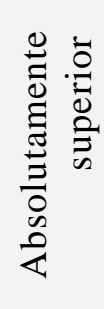 \\
\hline \multicolumn{5}{|c|}{ 5. Tratamento térmico (Incineração) } & \multicolumn{4}{|c|}{$\begin{array}{c}\text { Tratamento biológico e térmico (Biodiges- } \\
\text { tor Anaeróbio) }\end{array}$} \\
\hline 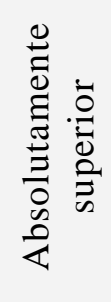 & 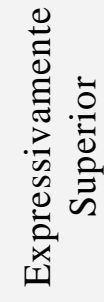 & 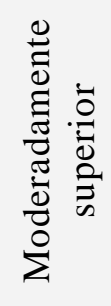 & 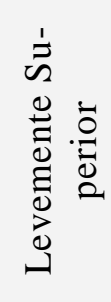 & $\begin{array}{l}\stackrel{0}{\Xi} \\
\frac{0}{\pi} \\
\stackrel{\Xi}{\Xi} \\
\underset{I}{J}\end{array}$ & 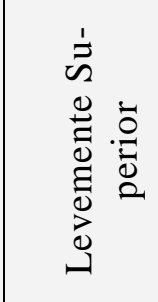 & 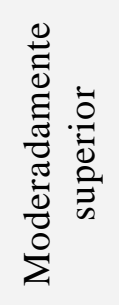 & 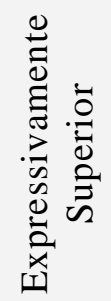 & 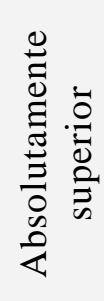 \\
\hline & & & & & & & & \\
\hline
\end{tabular}

Considerando o Custo de Implantação de cada tecnologia, atribua uma nota entre 1(um) e 10 (dez). Uma nota 1 (um) indica um custo elevadíssimo e uma nota 10 (dez) indica um custo baixíssimo.

Custo de Implantação de Aterro Sanitário:

Custo de Implantação de Incinerador:

Coleta de Implantação de Biodigestor Anaeróbio:
Nota:

Nota:

Nota: 
c) Compare as tecnologias apresentadas em relação ao CUSTO DE IMPACTO\&\&8 Nesta etapa, somente leve em conta os custos dos impactos, não considere outros custos.

Para efeito de sua comparação, considere: CUSTO DE IMPACTOS como sendo composto por todos os custos diretos e indiretos relativos as externalidades do processo de utilização de uma determinada tecnologia (Aterro Sanitário; Tratamento Térmico - Incinerador; e Tratamento Biológico / Térmico - Biodigestor Anaeróbio). Esses IMPACTOS são de natureza sociais, ambientais, políticos e à saúde, dizendo respeito a todo o ciclo de vida da instalação (projeto, instalação, operação, descomissionamento e passivo).

\begin{tabular}{|c|c|c|c|c|c|c|c|c|}
\hline \multicolumn{5}{|c|}{ 1. Aterros sanitários } & \multicolumn{4}{|c|}{$\begin{array}{l}\text { 2. Tratamento biológico e térmico (Biodi- } \\
\text { gestor Anaeróbio) }\end{array}$} \\
\hline 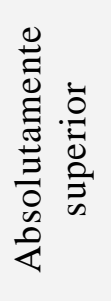 & 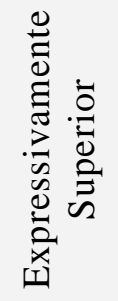 & 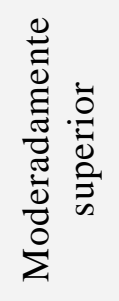 & 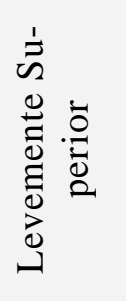 & 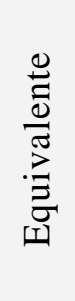 & 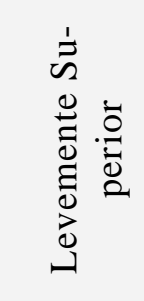 & 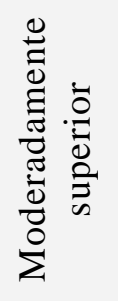 & 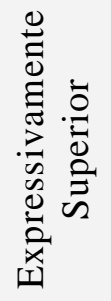 & 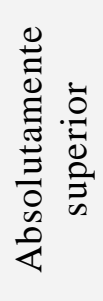 \\
\hline \multicolumn{5}{|c|}{ 3. Aterros sanitários } & \multicolumn{4}{|c|}{ 4. Tratamento térmico (Incineração) } \\
\hline 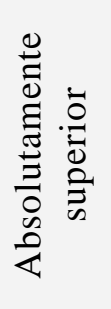 & 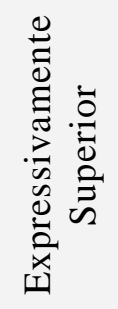 & 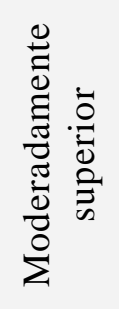 & 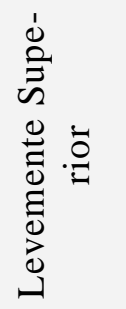 & 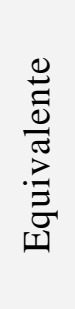 & 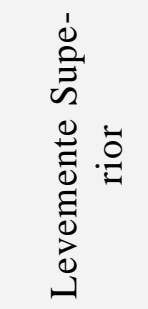 & 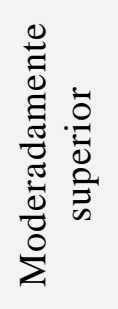 & 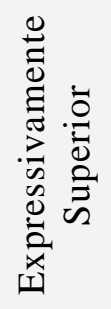 & 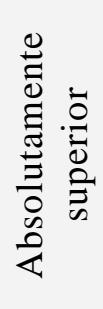 \\
\hline \multicolumn{5}{|c|}{ 5. Tratamento térmico (Incineração) } & \multicolumn{4}{|c|}{$\begin{array}{c}\text { Tratamento biológico e térmico (Biodiges- } \\
\text { tor Anaeróbio) }\end{array}$} \\
\hline 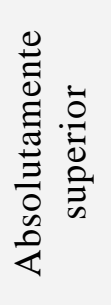 & 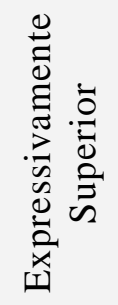 & 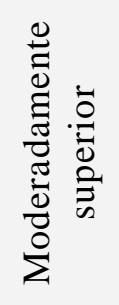 & 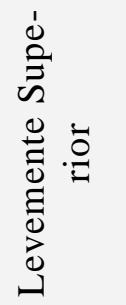 & 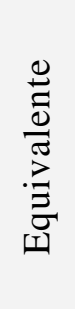 & 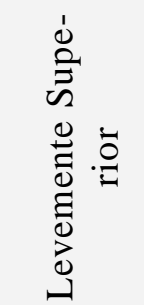 & 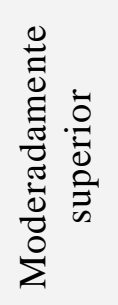 & 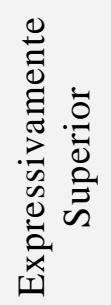 & 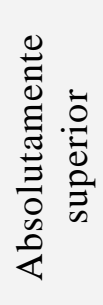 \\
\hline & & & & & & & & \\
\hline
\end{tabular}

Considerando apenas o Custo de Impactos de cada tecnologia, atribua uma nota entre 1(um) e 10 (dez). Uma nota 1 (um) indica um custo elevadíssimo e a nota 10 (dez) indica um custo baixíssimo .

Custo de Impactos de Aterro Sanitário:

Custo de Impactos de Incinerador:

Coleta de Impactos de Biodigestor Anaeróbio:
Nota:

Nota:

Nota: 